\title{
só existo em terceira pessoa
}

leandra carvalho do espírito santo 
só existo em terceira pessoa

Tese de doutorado apresentada ao programa de Pós-graduação em

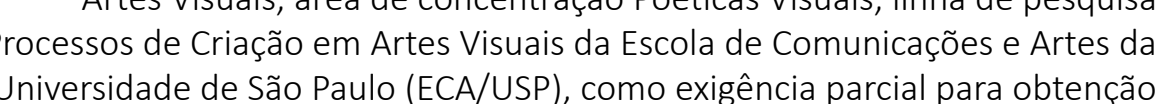
Universidade de São Paulo (ECA/USP), como exiêencia parcial para obtenção
do titulo de Doutora em Artes Visuais, sob orientação do 


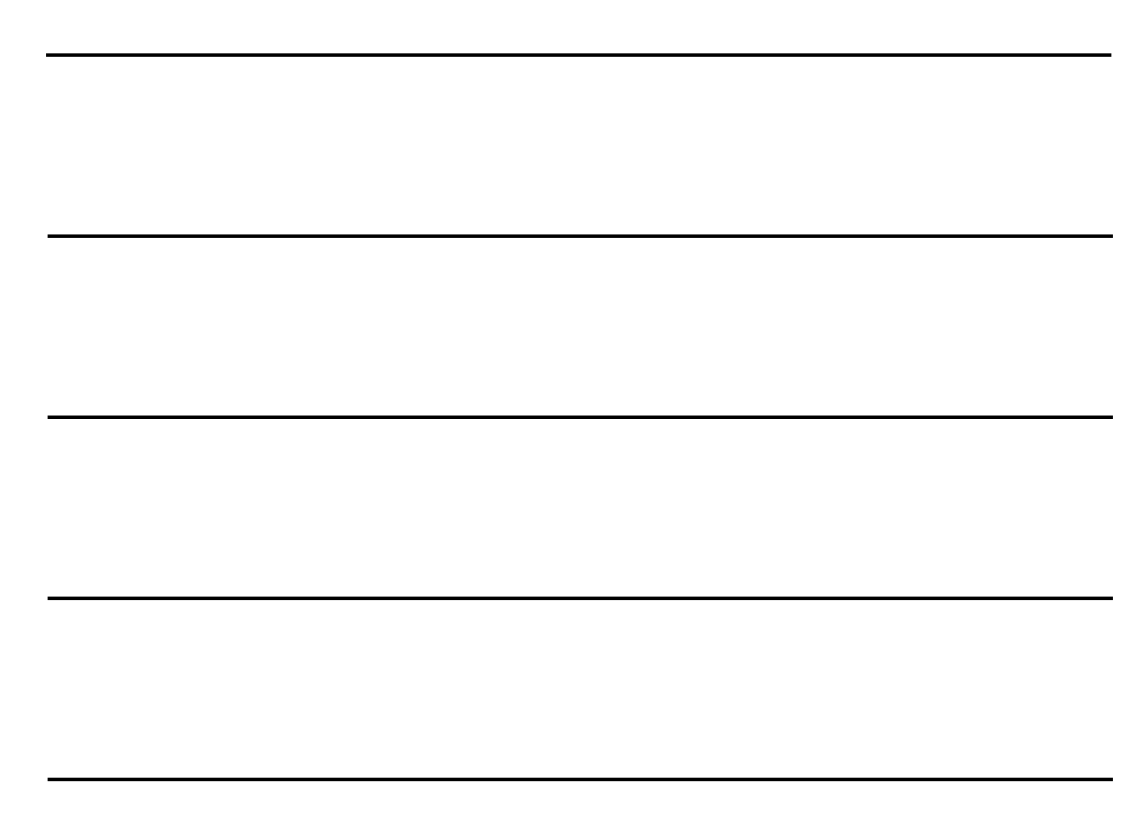

Data de aprovação: 
Esta tese é resultado de uma pesquisa de doutorado teórico-prático, onde abordo meus trabalhos autorais. Partindo de um processo artístico que se interessa por tematizar suas maneiras de fazer, onde os trabalhos vão surgindo em meio a um fluxo de acontecimentos, o texto se foca em abrir esse processo e apresentá

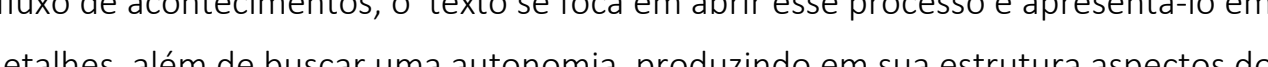
desenvolvimento. Os trabalhos vão sendo apresentados individualmente, agrupados em capitulos que apontam noç̃es e procedimentos fundamentais para sua elaboração. As questôes que mobilizam a criação partem de características de uma produção em série que alia corpo e máquina para determinada feitura de objetos, criando gatilhos para pensar a padronização e o entrelaçamento entre corpo e tecnologias. Em meio a esse interesse, incorporo o tema da autorrepresentação, que é pensado dentro do contexto atual onde o universo da "selfie" integra a representação de si aos habitos comuns, alimentada pelas relaçōes em redes virtuais. Nessa abordagem, vai se refletindo sobre a construção de subjetividades a partir da relação com o externo, da reprodução de comportamentos e desse corpo mediado pelas tecnologias.
This thesis is the result of a theoretical-practical doctoral research, where lapproach my art practice. Therefore, I start observing that my artistic process is focused on thematise its own procedures, its own methods, which emerge from a flow of events. The text is focused on opening up this process and presenting that in detail. However the text seeks autonomy bringing into its structure aspects of the ant are fundamental to their elaboration. The questions that mobilize creation start from characteristics of a serialised production that combines body and machine for a specific object making, allowing to think the standardization and the intertwining between body and technologies. Amid this interest in the relation of body and

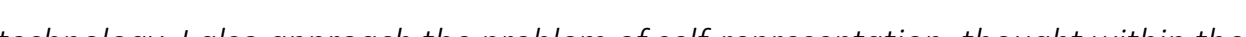
technology, lalso approach the problem of self-representation, hiought within the

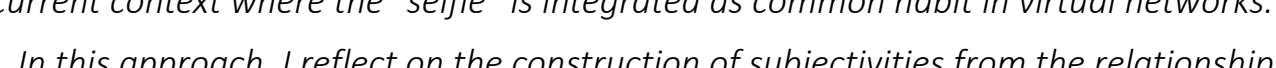
this approach, I reflect on the construction of subjectivities from the relationship with external models, the reproduction of behaviors and that body mediated by technology.

KEY-WORDS: contemporary art; artistic process; body x technology; selfrepresentation; construction of subjectivities; standardization. 
À CAPES pela bolsa de pesquisa que foi fundamental para o desenvolvimento e para

$$
\text { a realização do doutorado a partir do campo das Artes Visuais. }
$$
Ao meu orientador professor Hugo fortes pela confiança na pesquisa e pelo professora Branca de Oliveira e ao professor Marcelo Dennny pelas discipilinas que tanto contribuiram com o desenvolvimento dos trabalhos. Ao professor Mário Ramiro pelas trocas durante o Estágio Supervisionado. Ás professoras Sônia Salzstein e Priscila Arantes pelas contribuiçōes no exame de

$$
\text { qualificação que motivaram novos encaminhamentos para a tese. }
$$
Ao Renato Pera pela presença, parceria e dedicacão durante o doutorado. A Paola Fabres e ao Renan Marcondes pelo diálogo e pela atenç̧ão, fundamentais À minha familia pelo apoio eà minha mãe para a finalizaçăo dessa tese. Ao Chico por todo estimulo e companherismo. Ao Ary è è Eline pelo acolhimento e pelo carinho dério. 


\section{sumário}

fluxo um | primeiro | anterior

corpo matriz

"IMAGEM"

$$
\text { "CAPA" }
$$

"SIM, NÃO, TALVEZ"

"MAKING OFF"

III. objeto índice

"CHÃO"

"SEM TÍTULO"

"O DUPLO"

"TOTEM"

"LINHA"
"POSITIVO"

IV. só existo em terceira pessoa

IV. so

origens

anexo II: vídeos

bibliografia consultada

ficha técnica dos trabalhos 
fluxo

Este texto é resultado de um processo de pesquisa de doutorado teórico-prático, onde abordo meus trabalhos artisticos. As etapas desse processo envolvem projetos, conceituação, desenvolvimento prático (pesquisa de materials, manutatura de objetos, experimentacăo de objetos nos espaços etc), realização de exposiç̧̄es, leituras, observação, reflexões, discussões, reestruturaç̄es, reformulaçōes, escritas, apresentaçōes. Essas etapas ora são lineares, ora simultâneas, ora se interpenetram, ora se realizam de modos estanques para se cruzarem novamente.

Nesse contexto, a teoria, que vem conduzida pela prática artística, parece informar o processo de modos diferentes a cada etapa: esclarece ideias, instrui procedimentos, indica

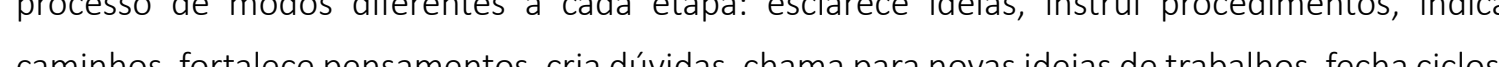
recomesa, cria uncampo de refleres, recomsa, cria na car de derita organiza um fluxo de acontecimentos do processo artistico, entrelaça teoria e pratica, relaciona

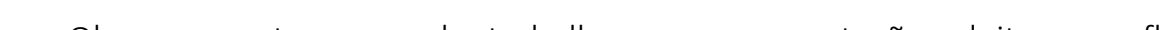

Observo quatro anos de trabalho, repasso anotações, leituras, reflexões, textos, faço relaçōes entre seus acontecimentos, puxo outras relaçoes antecedentes, rompo linearidades, crio parênteses no fluxo de acontecimentos, seleciono partes e vou reorganizando e estabelecendo um campo de sentidos latentes. A construçăo inicial do texto vai manifiestando, de modo espontâneo, aspectos recorrentes da produção, para então se tornar metodologia. Durante a escrita, incorporo conceitualmente esses aspectos e defino a estrutura textual, num exercício de produzir com a linguagem escrita alguns efeitos também gerados pelos próprios trabalhos. A estrutura do texto 
trabalhos. Além de ser meio para apresentaçăa, o texto também vira tema. Metalinguagem. propria maneira de fazer, numa coluna central, o texto segue um caminho descritivo e se foca em abrir essa construção dos trabalhos e apresentá-la em seus pormenores. A forma descritiva aqui mostra uma metodologia que instrui o modo de operar do próprio processo. Traz uma abordagem meticulosa de pensara a composição do trabalho artístico, decompondo seus detalhes e discorrendo sobre os vários tipos de elementos que estruturam e constroem sentidos.

Paraleamente a texto central descitivo posiciono uma segunda coluna de texto onde vou na de notas vai criando uma atmosfera de leitura dos trabalhos, uma ambiência, pretend

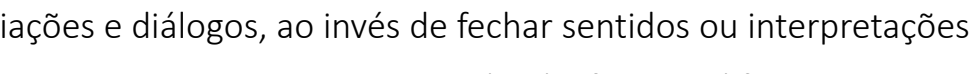

Essas notas vão se conectando de formas diferentes com o texto central no decorrer da leitura: ora são numeradas e partem de algum ponto do texto e o explica; ora abrem um pensamento; ora aparecem sem numeração e funcionam criando uma ambiência geral para o

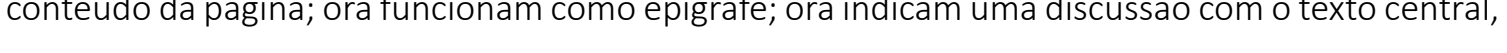
ou com as notas anteriores. Com esse campo de caminhos assinalados, o texto deixa espaço para que quem o leia crie sua maneira de transitar. Assim, enquanto texto, pretende operar mantendo criação de sentidos em pulso.

Depois dessa introdução, sigo apresentando "Incubadora", trabalho anterior ao doutorado que é exibido na base de seu projeto. Desde 2013, "Incubadora" vem sendo exposta em diversas ocasiôes com modificaç̧es que seguem as especcificidades de cada espaço expositivo. Descrevo sua elaboração e escolho abordar o momento expositivo que possibilitou sua apresentação mais completa, em 2014. "Incubadora" surge por dentro do processo de feitura de um trabalho cuja produçăa repetitiva, mecânica e corporal retoma um tipo de produção fabril em que o corpo ainda está em relação direta com as máquinas para a produção do objeto/produto final. Nessa relação acroônica entre corpo e máquina, o que val tomando foco e a mutua influência entre um e outro, alguns dos movimentos corporais para criação de seus mecanismos, depois é o corpo que é ritmado a partir da relação com as máquinas. Com o tempo, essas relaç̄es entre corpo, máquinas e outras tecnologias vão se complexificando, sugerindo cada vez mais seu entrelaçamento, num ciclo de cruzamentos e mediacôes que fica difícil determinar onde começa a interferência de um sobre o outro. "Incubadora" instaura, então, campos de interesses, de procedimentos, modos de fazer e pensar o processo artistico aue acabam sendo importantes para a litura dos trabalhos que

Nos capitulos subsequentes, apresento um conjunto de trabalhos produzidos durante - doutorado, que partem de uma temática proposta em uma das disciplinas realizadas na pósgraduação: a autorrepresentação. O tema reflete sobre o contexto atual onde o universo da "selfie" integra a representação de si aos hábitos comuns, alimentada pelas relaçōes em redes virtuais, Nessa abordagem, vai se pensando a construção de subjetividades, a padronização de comportamentos a partir desse corpo mediado pelas tecnologias-aqui representadas por câmeras fotográficas, celulares, computadores, e outras tecnologias de comunicação.

Cada capitulo é introduzido por questôes gerais sugeridas por seus titulos, que organizam noç̃es, procedimentos e reflexões de um conjunto de trabalhos, mostrando a conexão entre eles. Os trabalhos, então, são apresentados individualmente, um após o outro, sem mediaçōes ou explicaçōes. Na medida em que vão sendo apresentados individualmente, outras reflexões vão se formando por dentro de sua conshichăo, somando-se as antentores para compreensão geral dos interesses do processo. As situaç̧êes as qualis tais trabahtos se articulam tambeem são descritas visto que a maioria deles e pensada de acordo com os espaços expositivos. Assim, as questões vão surgindo por dentro dos trabalhos e, apesar dos agrupamentos em capítulos, os aspectos abordados no texto fundamentam toda essa produçăo realizada durante o doutorado, 
tangenciando cada trabalho de forma mais ou menos direta.

segundo e o terceiro capitulos agrupam trabalhos sem seguir uma linearidade tempora, mas sim conceitos primeiros que foram estruturando sua elaboraçăo. Partindo de um pensamento sobre a desmaterialização do corpo, e de uma dúvida atual sobre a verossimilhança entre corpo e suas representaçōes e imagens, o grupo de trabalhos apresentados vai manifestando um interesse em pensar os códigos que direcionam a representação de si atualmente, assim como as técnicas de produção de imagem hoje. Assim, o segundo capítulo discute o "corpo matriz" apresentes do

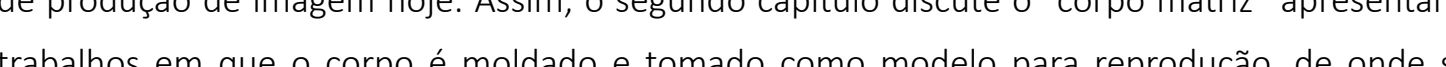
pacha distanciamentos entre colpo ser ferindo nas imasens finais do corpo representado. "

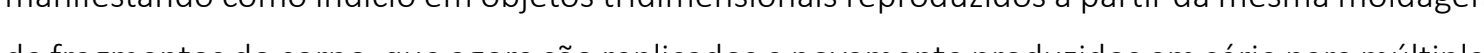
situacôes expositivas. situaçōes expositivas.

No capitulo quatro, apresento um projeto de exposição individual que recebe o mesmo nome da tese, "Só existo em terceira pessoa", realizado coincidentemente no último ano de doutorado em 2019. A exposição propõe possíveis diálogos entre a produção apresentada (trazendo outros trabalhos que se relacionam com a temática), discorrendo também sobre suas relaçōes com espaço expositivo em questão. A construção de subjetividade vai sendo pensada a partir da relaçăo com o externo, sendo que esse elemento externo pode ser tanto o outro-sujeito, quanto o outroobjeto, o outro-ambiente, o outro-tecnologia.

No capitulo final, "origem", trago algumas consideraç̧̄es sobre a elaboração desse tex articulando as características do processo de escrita à construção dos trabalhos apresentados, apontando ainda para a importância de se observar processos de elaboração, dado que os traballhos văo surgindo em meio aos seus fluxos de acontecimentos.

Em anexo, trago uma leitura breve de um conjunto de trabalhos também finalizados na época do doutorado, que não seguem a mesma temática da autorrepresentaçăo, mas se relacionam com os trabalhos aqui apresentados principalmente por seus procedimentos, e apontam outros horizontes para aspectos desse processo. Assim como a fotografia e a moldagem do corpo na escultura, nesses trabalhos, o procedimento usado fixa e paralisa o tempo numa matéria, além de demonstrarem um interesse em cotalogar comportamentos culturais, que vão se relacionar como corpo a partir do alimento.

Escolho a palarra fluxo para iniciar esse texto e falar de um processo criativo que, apesar de,

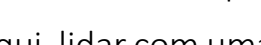

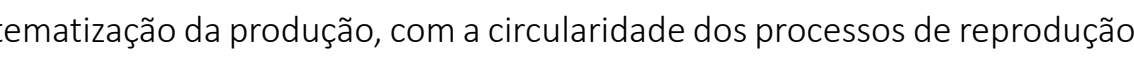
repetição e padronização, assume também uma condição do estar em fluxo. Processo que cria metodos, mas também incorpora desvios, numa dinâmica que alia sistematizaç̃o e i improviso,

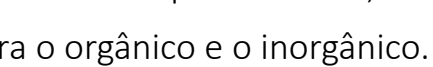


um | primeiro | anterior

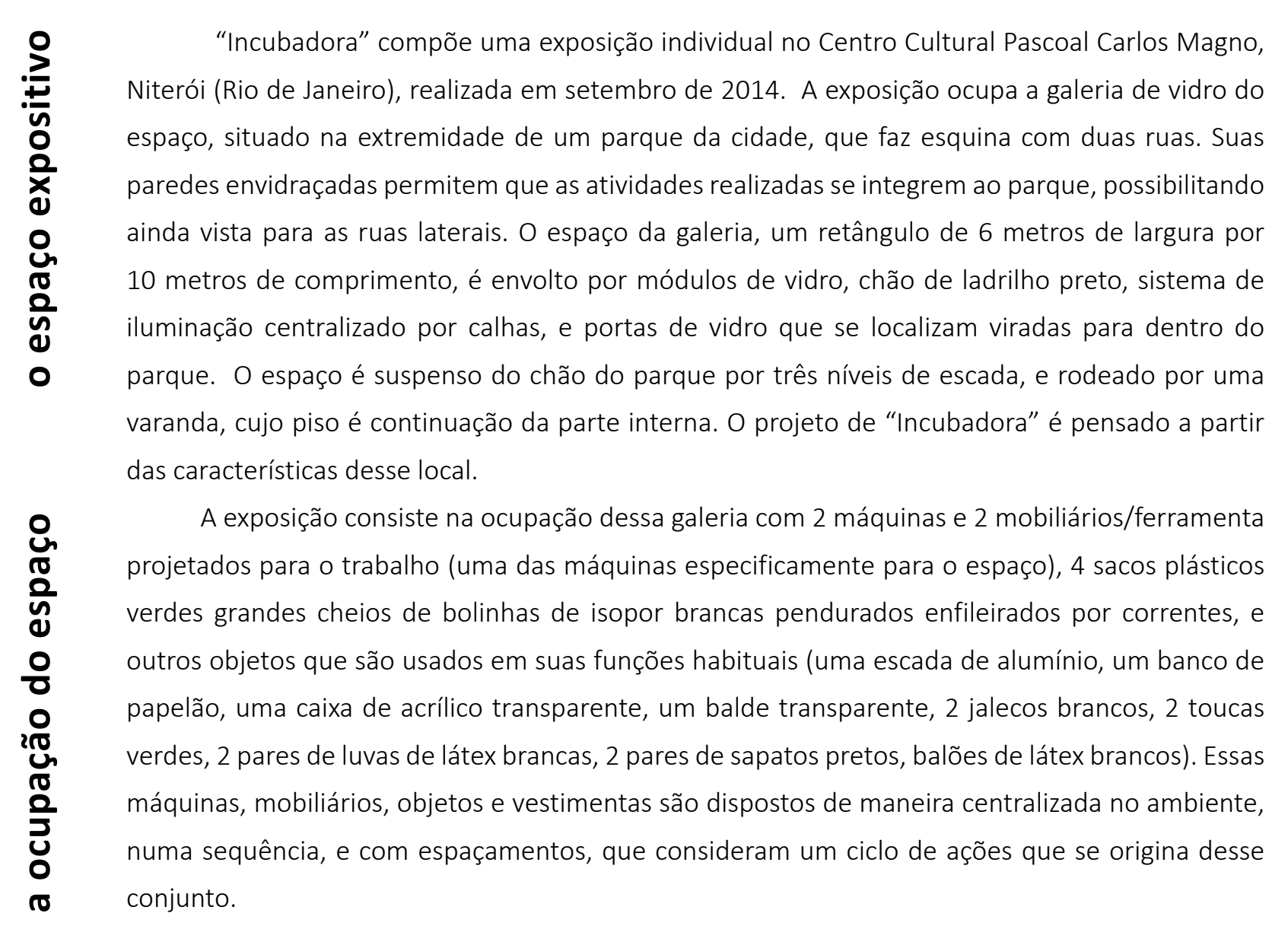




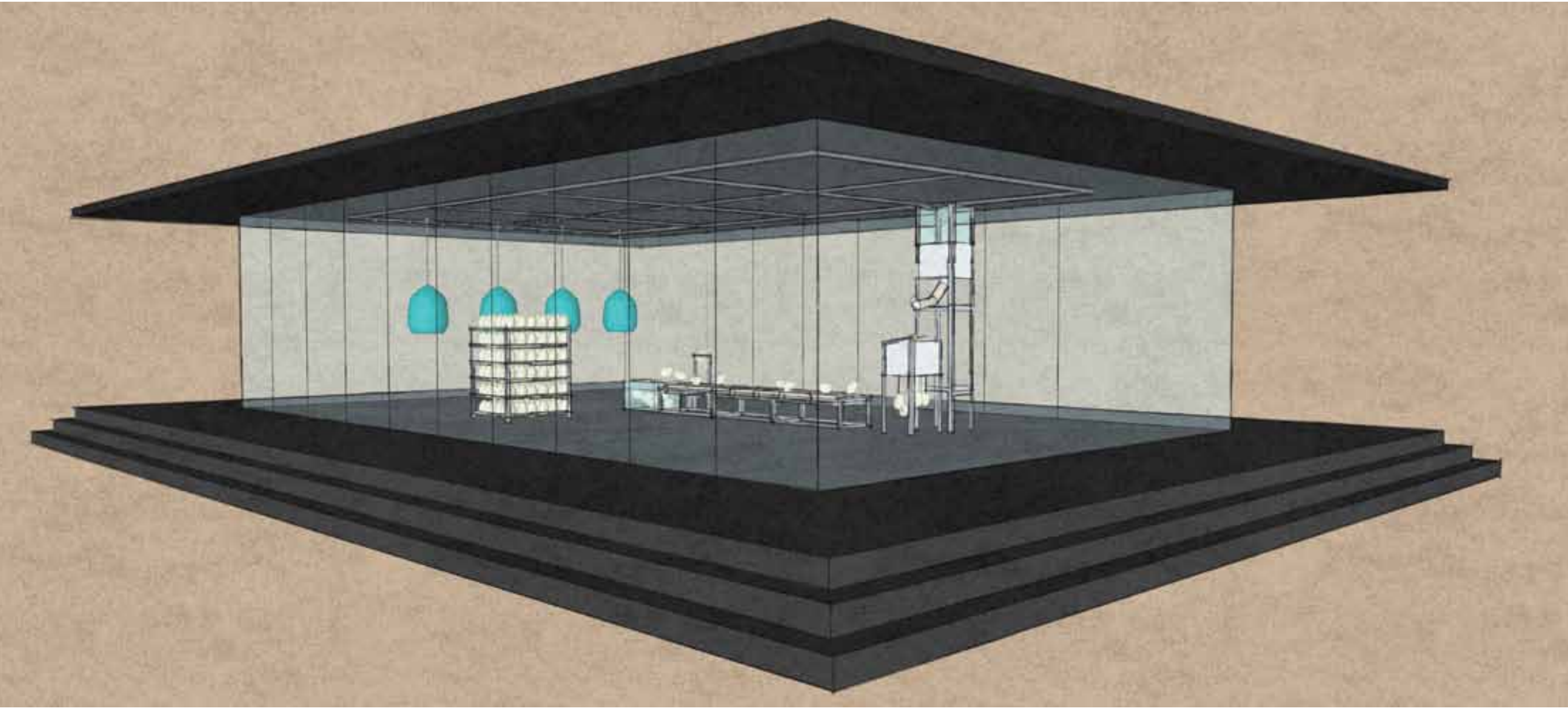

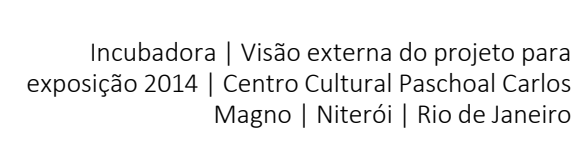

Durante a abertura da exposição, entramos na galeria eu e mais uma pessoa, a porta de vidro é fechada, vestimos as roupas, posicionamo-nos diante de uma das máquinas, e comeccamos a realizar ações que vinculam nossos corpos aos elementos instalados no espaço, e os elementos entre si. Durante a ação, nos dividimos em 10 tarefas específicas e nos mantemos repetidamente nas mesmas tarefas até o fim. As açōes são realizadas em movimentos corporais comuns, que se repetem constantemente. Nossos corpos não se aceleram, nem se acalmam, seguem a instrução de se manterem firmes, concentrados e constantes durante a ação, e eretos nos momentos de espera 0 píblico se matem fora do espaç, circulando a sala de vidro, observando a ara Do

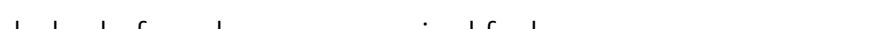
acontecendo na sala que, de noite, tem iluminação interna mais evidente que a externa, deirando

Otrabalho cria um circuito de produção' de balöes de látex preenchidos com bolinhas de isopor. Os elementos básicos criados para esse circuito são a máquina de encher balōes com bolinhas de isopor, o funil, a esteira e a empilhadeira. A ação termina quando os 128 espaços da empilhadeira estão ocupados com balöes cheios. Duração média de 2 horas e 30 minutos. 0,85 balōes por minuto-menos de um balăo por minuto.

"Incubadora" se realiza na relação entre corpos, ações, objetos, espaço e público. Nessa ocasião, o trabalho pressupõe dois momentos diferentes, um momento em que há uma ativação dos elementos básicos criados durante uma performance na abertura- e em outra data durante a exposição, e o momento em que esses elementos ocupam o espaç̧o enquanto exposição. Cada um desses momentos pressupoõe uma relação diferente com o público.

titullo² do trabalho surge da relação entre a proposta, que traz a criação de objetos informes (balöes cheios) que, por sua aparência, retomam o orgânico, e o espaç̧o de vidro que, em conjunto com os objetos produzidos, retoma a imagem de uma incubadora.

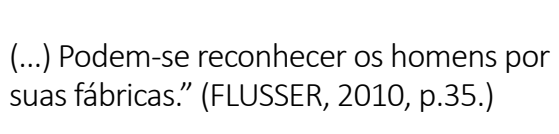

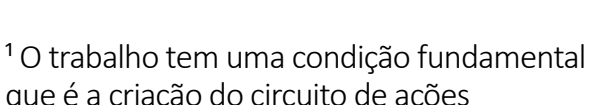

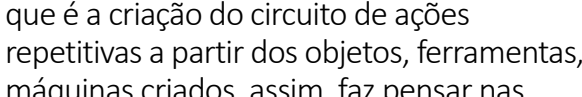

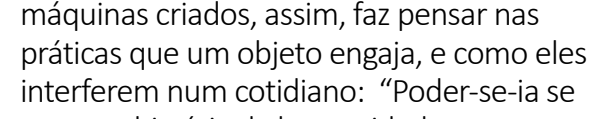

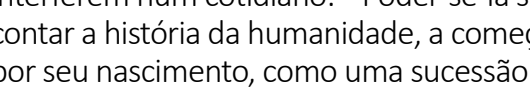

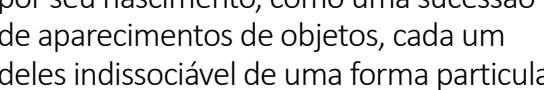

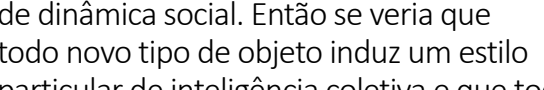

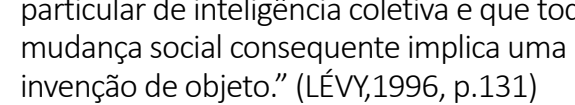

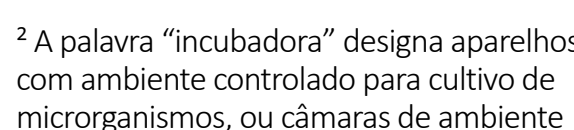
microrganismoss, ou cammaras de ambiente
controlado para recém-nascidos. No meio

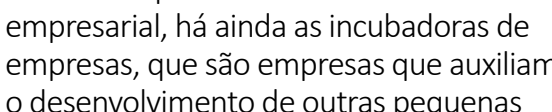
empresas. 


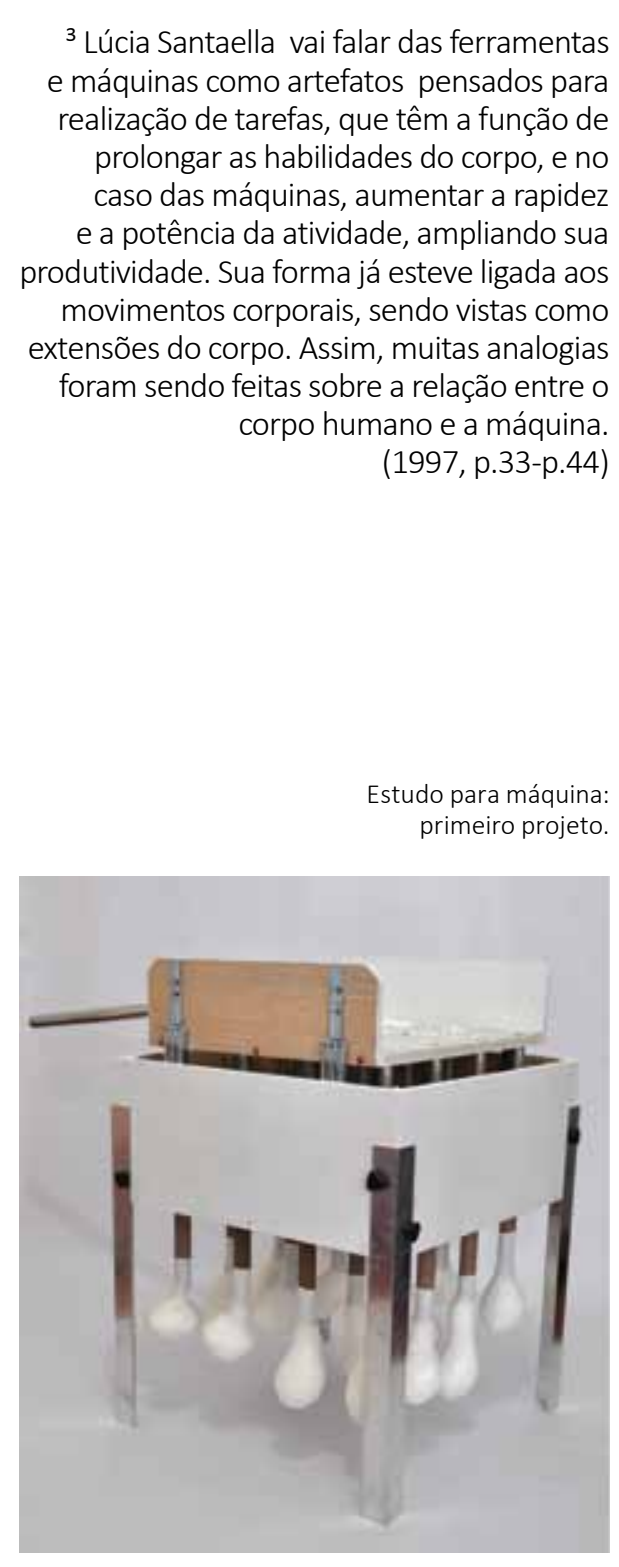

Amáquina de encher balōes com bolinhas de isopor foicriada anteriormente paraessafunção, e os balôes eram utilizados em outro trabalho. Ela deixa de se constituir enquanto procedimento de trabalho e é ponto de partida para "IIncubadora". Semelhante às máquinas pré-industriais, seu funcionamento depende da forç̧ mecânica do corpo. Apesar do anacronismo $0^{4}$ de seu mecanismo, o móvel caseiro e o móvel de escritório. Sua forma é linear. funcional, sem elementos decorativos. Tendo sido projetada empiricamente, suas dimensões tomam como referência um corpo de 1,7

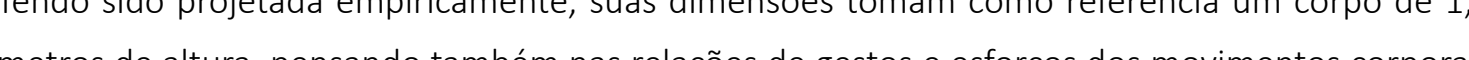

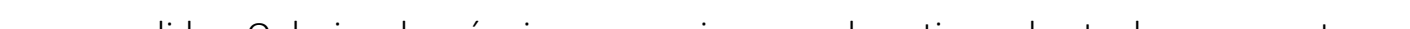
The

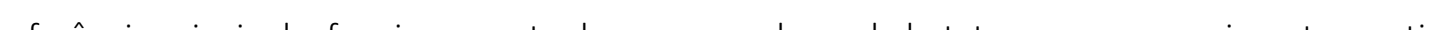
que se localiza no meio da ferramenta, soltando o alimento por baixo em outro formato. o mecanismo se vale de peças novas de outros tipos de sistemas, commo o de gaveteros para manter o eixo de movimentação e o de alavancas para ampliar o movimento e aumentar a pressão em sua manipulaçāo.

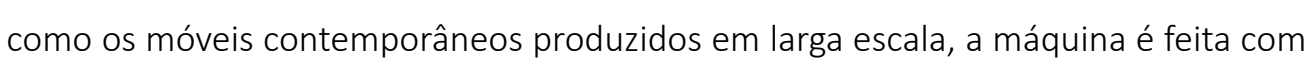
materiais de baixo custo, compensado naval, fórmica branca, alumínio, tubos de PVC e plástico. A primeira maquina projetada foi pensada para uso individual. Dessa primeira, foi preciso adaptar dimensões e a quantidade de canos para passagem do isopor, para ajustar o esforço de realização da tarefa. A máquina final se manteve mais ergonômica com 6 acessos. Tem 90 centímetros de altura, 40 centimetros de largura e 30 centímetros de profundidade. 


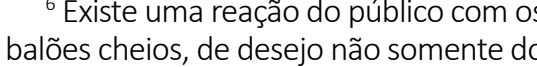

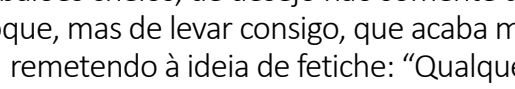
coisa pode se tornar um fetiche (...) ofeter
não e um deus ou uma deusa do politíisto

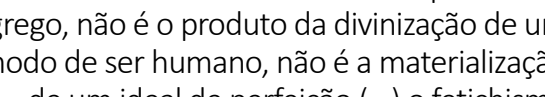
de um ideal de perfeição (...) o fettichisn tidade para entidade, investindo com sum sua abstraçăo tangivel, plantase animima

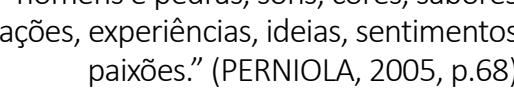

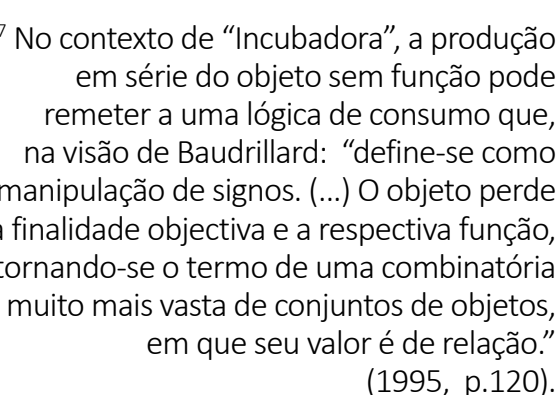

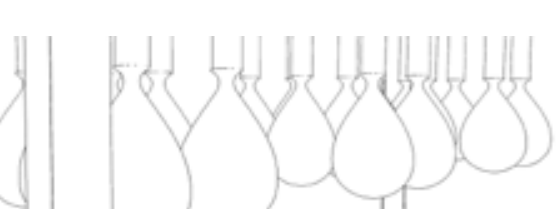

Os objetos produzidos a partir da máquina, balôes cheios de bolinhas de isopor, surgem a partir de 120 movimentos de subir e descer: 60 impulsos $\mathrm{e} 60$ empurröes. Săo todos semelhantes: alia máquina e manualidade, assim como da flexibilidade do material látex. Têm em média 11 centimetros de diâmetro. Cor considerada neutra, branco leitoso. Leve transparência que chama para o conteúdo interno. Característica informe. Textura fofa, maleável, de pele. Forma que se assemelha a algum órgão humano ou animal. São táteis, atrativos, curiosos, sem funcão. Objetos performativos. Não participam da esfera do objeto funcional, mas se mantên numa esfera de

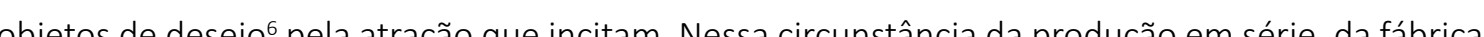

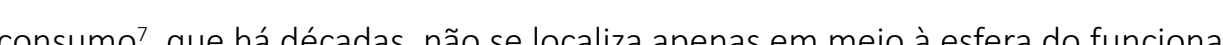

Entre máquina e objeto balâo preenchido juntos (como na imagem da primeira máquina na página 24), a imagem que surge tem caráter antropomórfico. Retoma tanto o inorgânico, como o orgânico. Imagem de robô artesanal arcaico.

Ambos, objeto balão e máquina são performativos. Possuem essa característica não por se movimentarem sozinhos como autômatos, mas porque cada um a sua maneira parece pressupor uma ação. A maquuina tem essa dimensão mais clara, sua existenncia se justifica a partir de sua manipulação. Ela chama para o descobrir de seu funcionamento. 0 balão cheio de bolinha de isopor, de uma maneira menos evidente, também parece subentender uma ação, parece chamar ao toque, à manipulação, à explosão.

Entre máquina, objeto balão preenchido, corpo e movimento corporal, outras imagens que surge. Magnetismo e encantamento pela máquina. Erotismo da friç̧ão e dos movimentos de subir e descer, entrar e sair. Criação. Magia. Ludicidade. Proliferação. Loucura do esforço de produção sem finalidade.
Aideia de "Incubadora" parte da máquina e vai se afirmando em meio a essa potência de ens em coexistência.

Seu projeto aprofunda o nonsense dessas relaçōes imagéticas criando um ciclo de produçãa que está imerso no universo tecnológico, e em suas ideias de funcionalidade e utilidade, invertendo, porém, a relação de eficiência e produtividade. Intersecciona modelos de fábrica obsoletos. Usa máquinas pré-industriaiais que se utilizam do esforço mecânico do corpo. Joga a aten nãa da produção para o corpo. Fragmenta as tarefas numa linha de montagem que remete às linhas de produč̃o fordista. Mantém parte de sua producão a no nivel do artesanal. Estende o tempo de produção. Retira a função do objetto. Produção em série.

Dador" pensam as necessidades da produção de balōes ios criados seguem a de encher. Outros parâmetros são definidos de acordo com suas funçōes e na relação com o espaço. Seguindo esses parâmetros, of esteira, empilhadeira.

f funil tem a função que seu nome indica. É composto por caixa de compensado branca, paredes de acrilico transparente, sustentados por perfis de aluminio. Sua altura final é de 2,8 metros, tendo 35 centimetros de profundidade e 46 centimetros de largura. As paredes de acrilico transparente possibilitam a visão do movimento das bolinhas de isopor descendo e saindo da caixa. A parte inferior da caixa possui um buraco por onde desponta um cano de PVC curvo de 15 centimetros de diâmetro, que faz um ângulo diagonal necessário para que as bolinhas escorram de sua caixa, passando pelo cano e escontendo para a maquina. Na ponta deste cano, una pea MDF móvel possibilita o controle da passagem das bolinhas de isopor. A peça abre e fecha.

Na busca de um formato para comportar as funçōes de armazenar e passar o isopor para a máquina- funçōes que se situam entre as de mobiliário e ferramenta- o funil resulta num formato de caráter tambeem antropomorrico, de apelo erótico

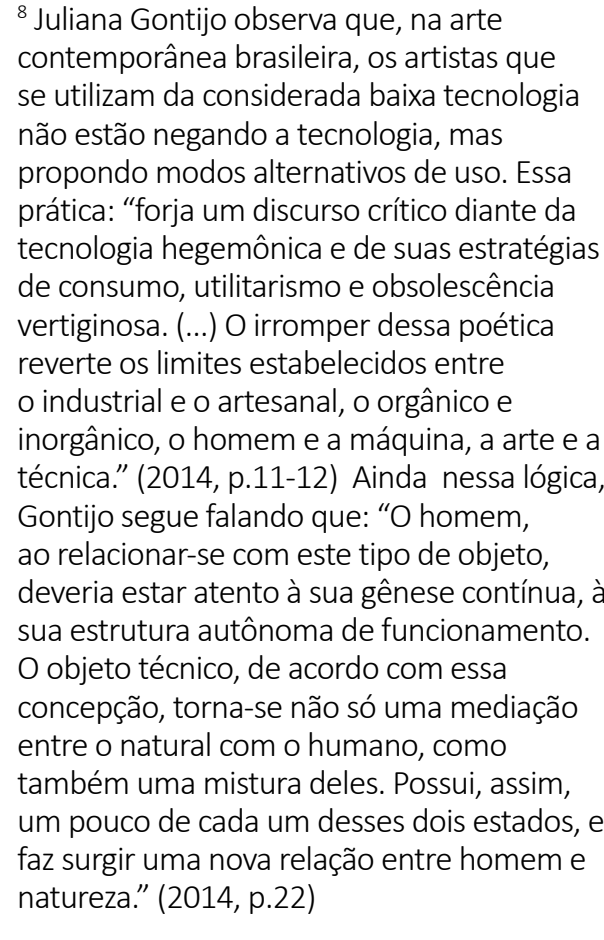




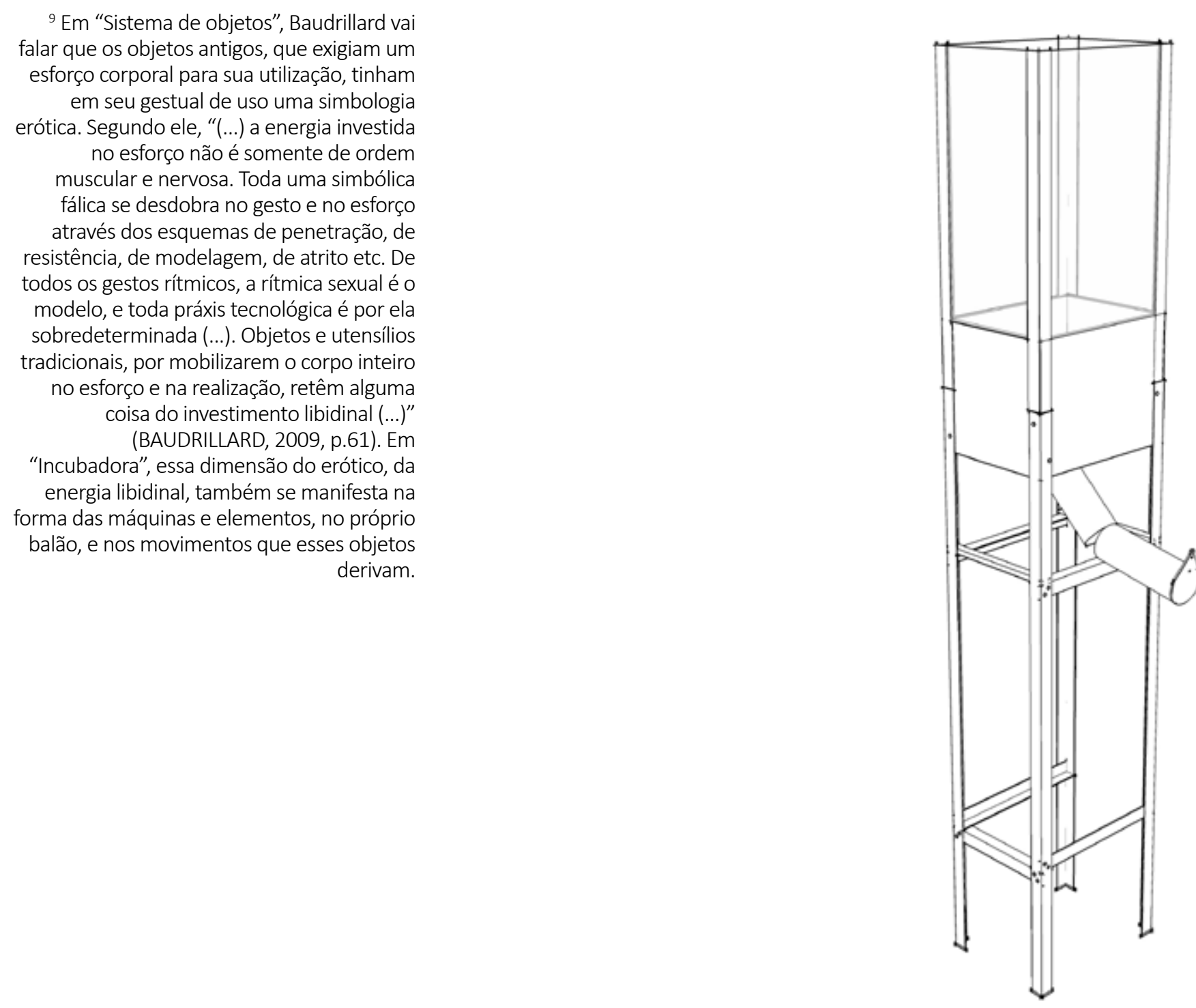

A esteira segue o desenho longitudinal do espaç̧o. Tem função de attravessar o balâo de uma ponta a outra, tendo 3 metros de extensão. Liga as atividades dos corpos que se situam em cada extremidade do espaç, trazendo uma caracteristica das linhas de montagem industriais. Porém, ao invés de se movimentar sozinha, enquanto os corpos interferem no objeto produzido, é o corpo que aciona a esteira para que o objeto balão se desloque. 0 objeto balão entra na esteira de uma maneira, e sai dela da mesma maneira, não passando por interferências durante o trajeto.

Suas dimensōes consideram a máquina de encher balôes e os gestos corporais ligados a seus próprios mecanismos É composta por 3 módulos tubulares vazados de ferro pintado de cinza com 1 metro de comprimento, por 30 centímetros de altura e 46 centímetros de bra do de cinza mecanismo tencon

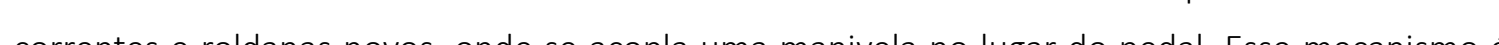

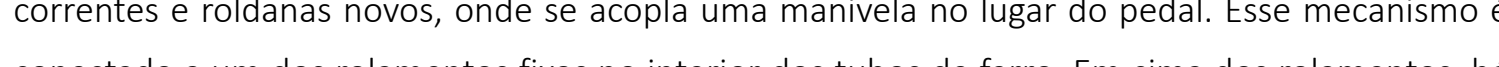
conecta

A empilhadeira é um móvel projetado para armazenar os balöes cheios de bolinhas de isopor. Sua estrutura e feita em perfis de aluminio com 8 andares. Cada andar suporta uma placa de MDF branca com 16 cortes circularesvarados. Inicalmente, todosos elementos devenam ter engentios que mobilizassem partes do corpo. A empilhadeira foi projetada para ter mecanismos de subir e engavetar. Nesse contexto, tem 1 metro de altura por 80 centimetros de largura e 70 centímetros de profundidade, e não possui mecanismos. 


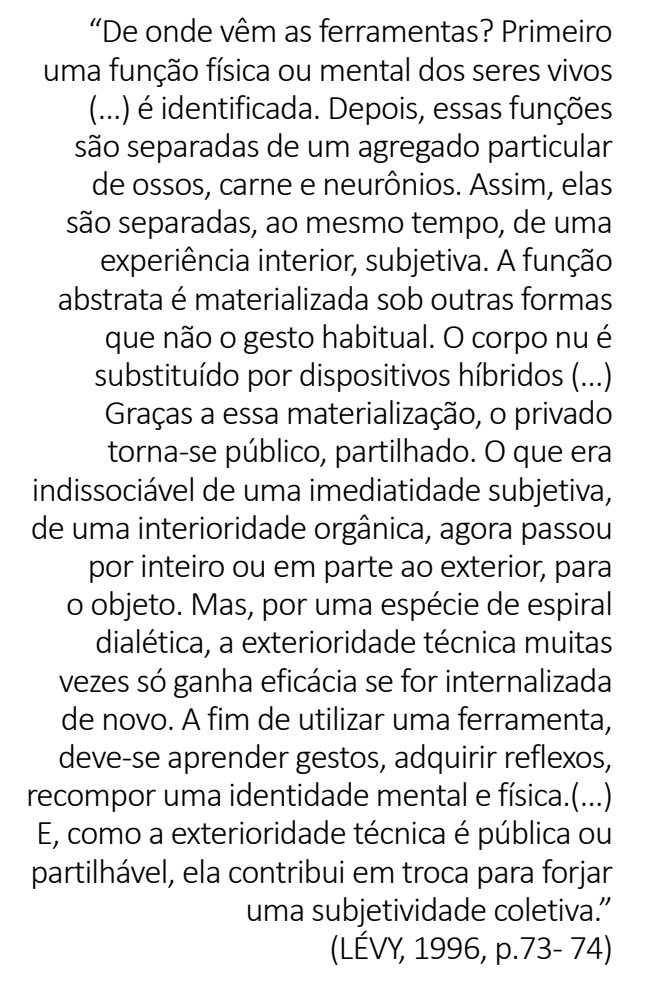

espaço expositivo da galeria com paredes externas de vidro, chão de ladrilho preto semi-

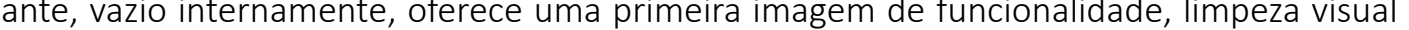
Eิ assepsia que condiciona sua ambiência - imagem de uma modernidade que ainda se perpetua (o projetados para a instalação no espaço segue essa mesma lógica somando à paisagem cores friazs - predominantes, branco, cinza e prata. O verde que está em detalhes dos utensililios (sacos de lixo ?. e toucas) ratifica a assepsia da imagem num tom irônico por sua literalidade - tat verde está em th elementos que são associados à limpera, aos ambientes hospitalares e laboratorias, Os outros

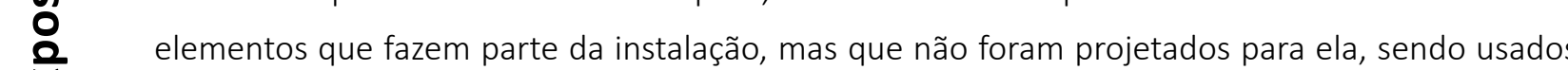

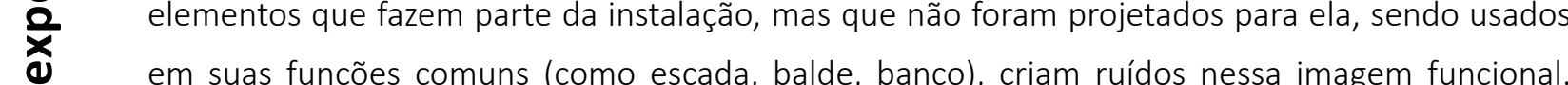
Outras lógicas de uso se apresentam. Desvio. Improviso.

As características das máquinas, ferramentas e objetos, do espaço e de sua ambientação chamam para multiplas referencias. Imagens superpostas de espaços e maneiras de uso do espaç̧o. apropriação.

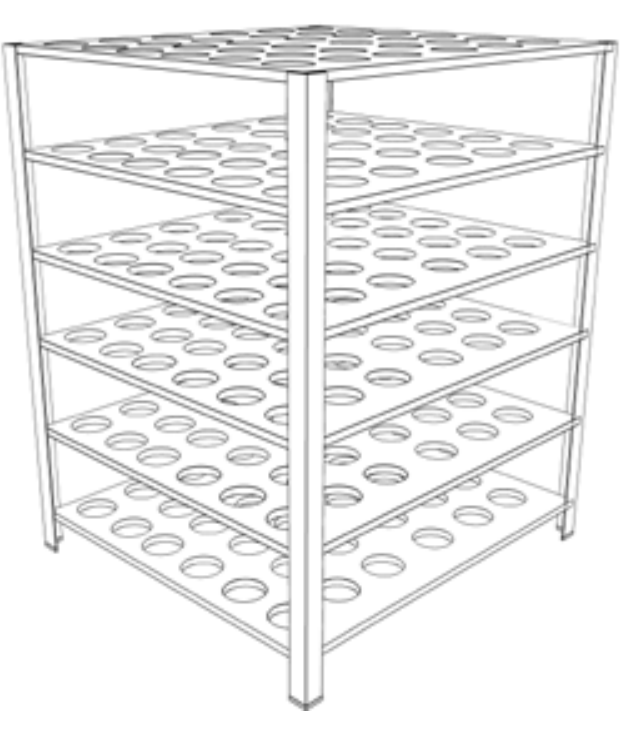




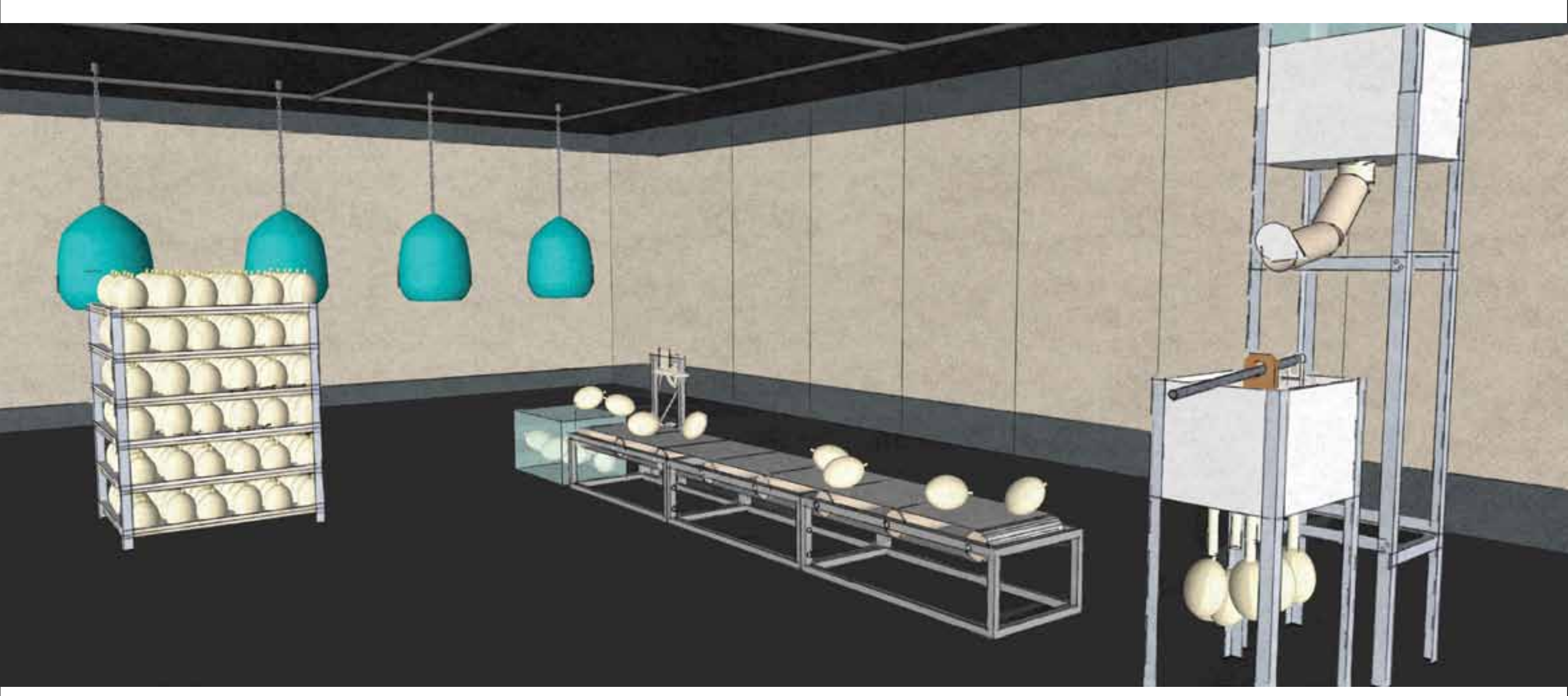

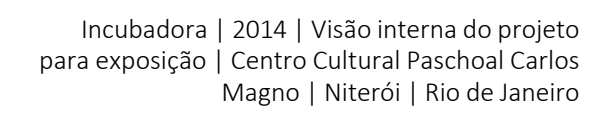

Os elementos criadossio para "Incubadora" estimulam à manipulação e ao movimento. A peformance sedả pela ação dos corpos que na relação comos elementos ativam seus mecanismos para produzir o objeto. A performance é a própria produção do objeto balâo preenchido com bolinhas de isopor $\mathrm{O}$ uso das máquinas é aprendido com antecedência. $\mathrm{A}$ habilidade com os objetos e máquinas vai se estabelecendo com o próprio uso durante a performance.

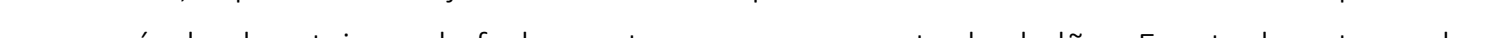

De noite, a iluminação interna do espaço deixa em destaque a ação.

Atravesso a sala, me posiciono e espero. 0 outro atravessa a sala, enche o funil com bolinhas de isopor, volta, se posiciona e espera. Realizamos movimentos comuns de caminhar, parar e de miter o corpo ereto.

Estico 6 baloes de litex brancos. Abro suas boca bro o funil. Com a passagem abenta, as bolinhas de isopor descem e jorram pelo cano de forma luida e acelerada, produzndo rudos do atnio com as outras partes dos elementos. Mão direita segura a alavanca do mecanismo da maquina, esquerda se apoia na caixa. Em seguida, braçoç e ombro direitos suspendem a alavanca do mecanismo, com seus 6 tubos de alumínio, deixando que as bolinhas passem pelos canos de PVC. O corpo está firme, levemente inclinado, usa a força dessa inclinaçẫo para empurrar a alavanca. Na medida em que mão, braço e ombro pressionam o mecanismo para baixo, os tubos de alumínio empurram as bolinhas de isopor pelos canos, e dos canos para os balōes. Durante esse procedimento, é necessário apertar os balöes para retirar áreas de pressão, para que ele consiga receber mais bolinhas sem estoura.

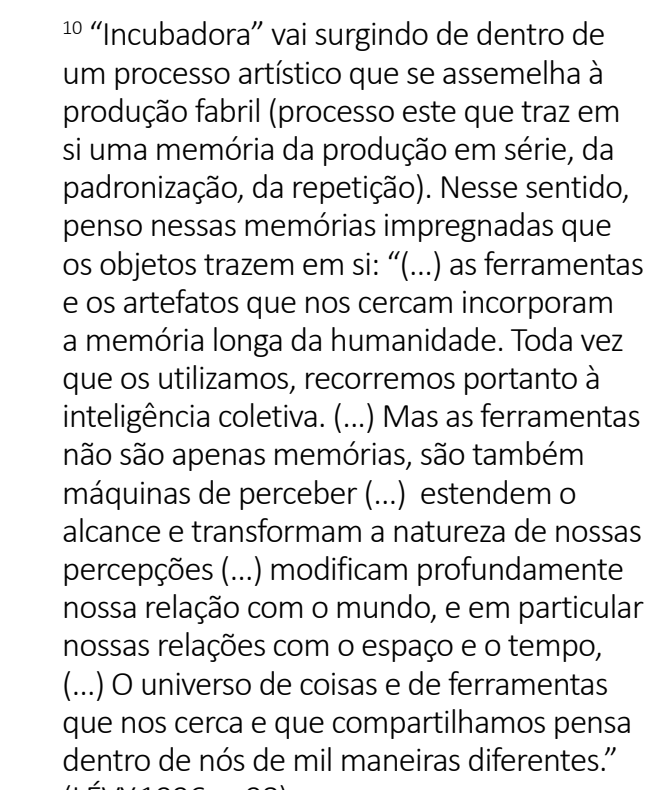

dentro de nós de
(LÉVY,1996, .98$)$ 
Os 6 balöes são cheios simultaneamente em movimentos repetitivos de subir e descer, ombros realizam movimentos repetitivos de subir e descer, as mãos, de apertar e soltar. 0 resto do corpo acompanha os movimentos principais, responsáveis por ativar a máquina e produzir o objeto. Meu corpo continua firme, levemente inclinado, atento. Os balöes estão cheios. O corpo abaixa. Uma mão segura a boca de um balão, a outra segura sua base, aperta e empurra o bal jo cheio para cima Em seguida, a mão de cima puxa a boca do balăo para baixo seguindo movimentos verticais de subir e descer, curtos e ránidos, enquanto a mão debaixo sustenta. Os 6 baläes stos Ualde transparente. Todas as acỗes geram sons, rúdos, estalos Esse Média de 0,85 balōes por minuto.

Despaço, que começa em sua assepsia usual, vai sendo tomado por bolinhas de isopor. 0 público observa a ação de fora. Circula o ambiente de vidro. Pode visualizar as açōes de vários ângulos. Pode parar num mesmo ponto. Pode desviar o olhar

Dentro da sala, o outro corpo está parado na outra ponta da esteira. Meu corpo agacha entre a máquina e a esteira, está virado em direşão ao outro. Minhas mãos apertam um balāo fazendo leve pressão em seu contorno até ficar oval, e o posicicona na esteira.

Com a mão direita, o corpo do outro roda a manivela da esteira, com a esquerda, se apoia no mecanismo. A manivela é girada em sentido horário, a corrente puxa o rolamento e faz a lona . Seu funcionamento produz sons, chiados e rúdos. 0 outro está levemente inclinado. Mantem o movimento da esterra cont 0 , nem rapido, nem lento. O baláo começa a se movimentar pela esteira, indo de uma ponta a outra. Minhas mãos apertam outro balăo, fazem pressão em seu contorno até ficar oval. Posicionam-no na esteira que continua em movimento ininterrupto, que parece lento ao olhar. Outro balăo se desloca de uma ponta a outra. Os intervalos entre os balô̌es
Tempo da conformação oval, 4 segundos em media. Os 6 baloes passam pela esteira em 32 segundos aproximadamente e caem na caixa de acrilico transparente.

Açoes simultâneas. Volto para a máquina e recomeço a encher os balôes com bolinhas de isopor. 0 outro se senta, pega um balão da caixa de acrilico, dá um nó, evolta com ele para a caixa. O outro realiza a mesma açăo com os 6 balōes. Depois, se levanta, pega a caixa de acrilico com os balốes, atravessa a lateral da sala, e posiciona os balôes cheios e fechados na empilhadeira, um a um. Um ciclo se fecha.

Durante 2 horas e meia, este ciclo se repete por uma média de 21,33 vezes entre os dois corpos, em açōes por vezes simultâneas, sempre ciclicas e continuas. Essa contagem considera breves pausas entre as acōes e entre os corpos".

Os 2 corpos de dentro stio cas cordos, atentos e firmes, são levados à exaustão 0 público também é évado à exaustão do ato de observar (e o leitor à èxastão do detalhe descivivo).

Depois de 21,33 ciclos, meu corpo e o corpo do outro atravessam a sala. Retiramos jalecos, toucas e luvas. Abrimos a porta de vidro e saímos da sala O $\mathrm{O}$ acesso fica aberto ao público.

Fim da performance.

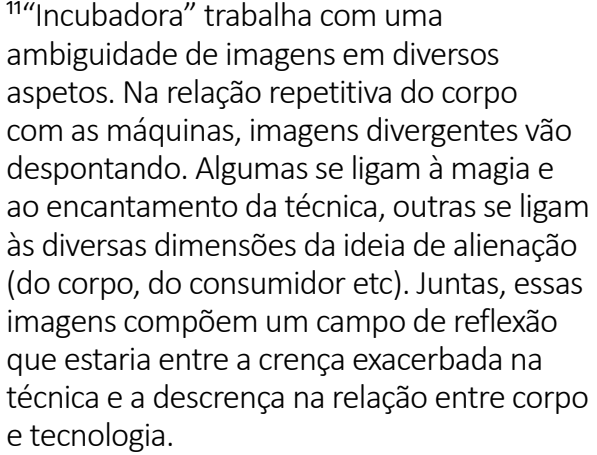

Links para assititi os videos relacionados à

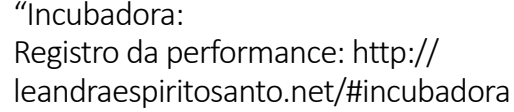





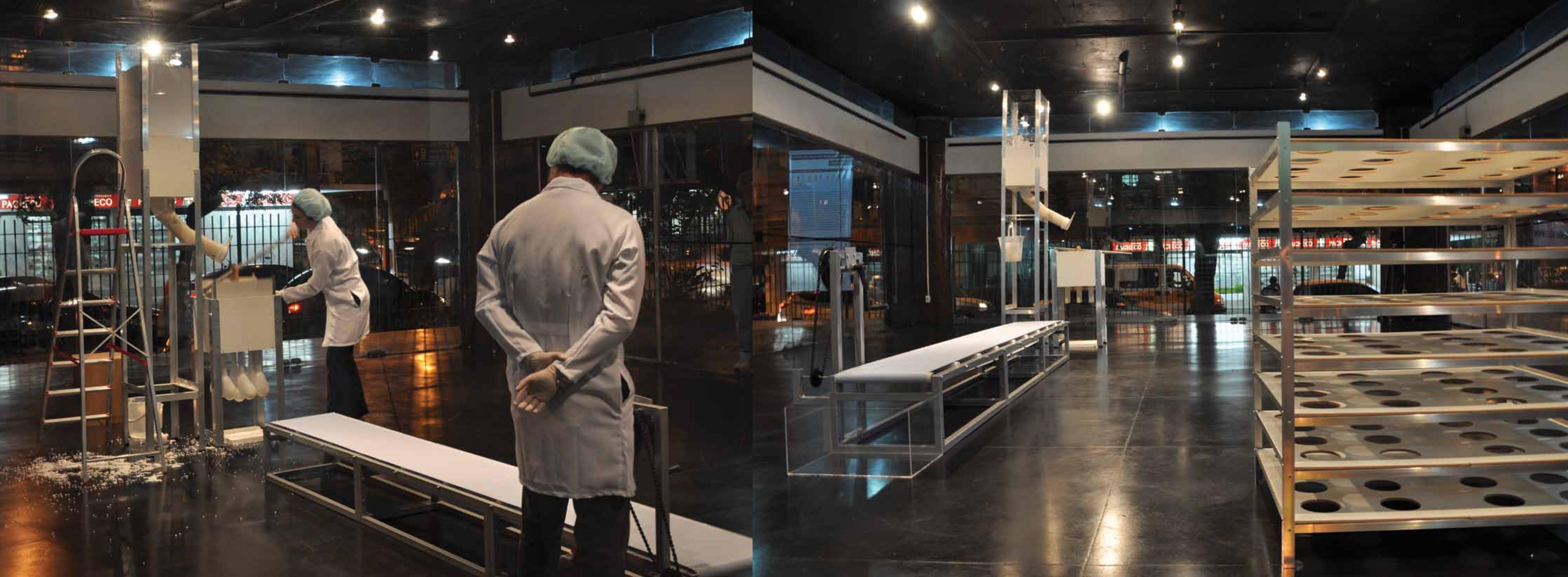




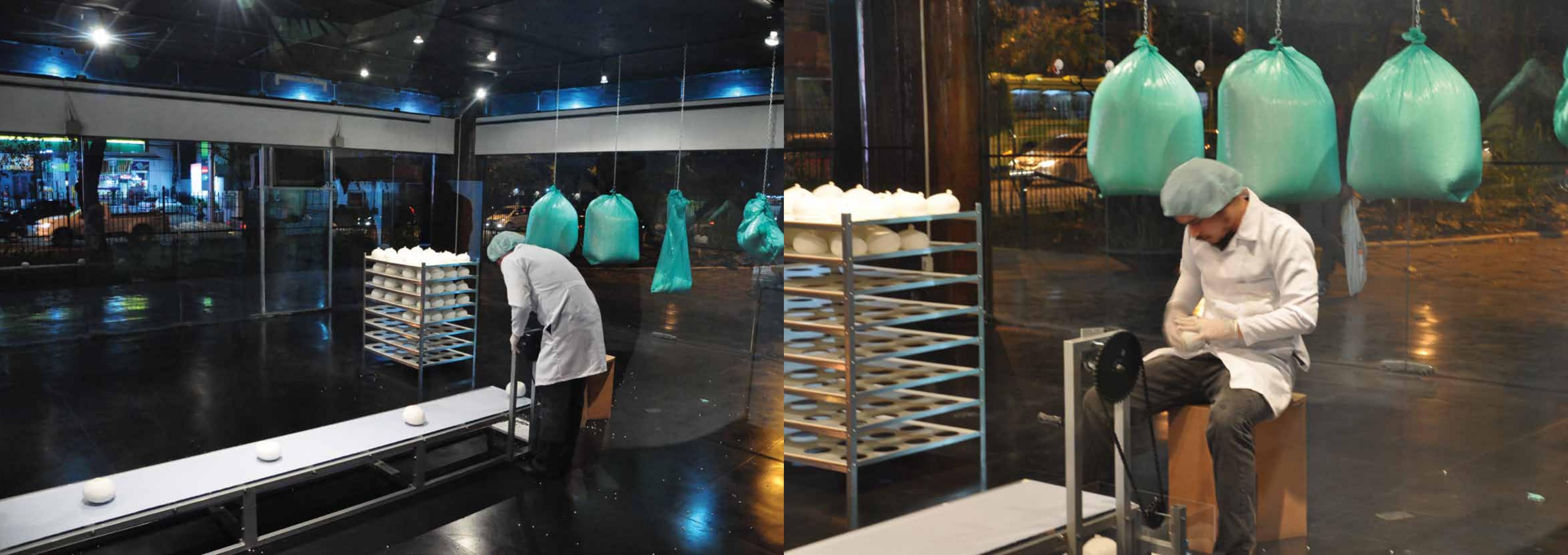




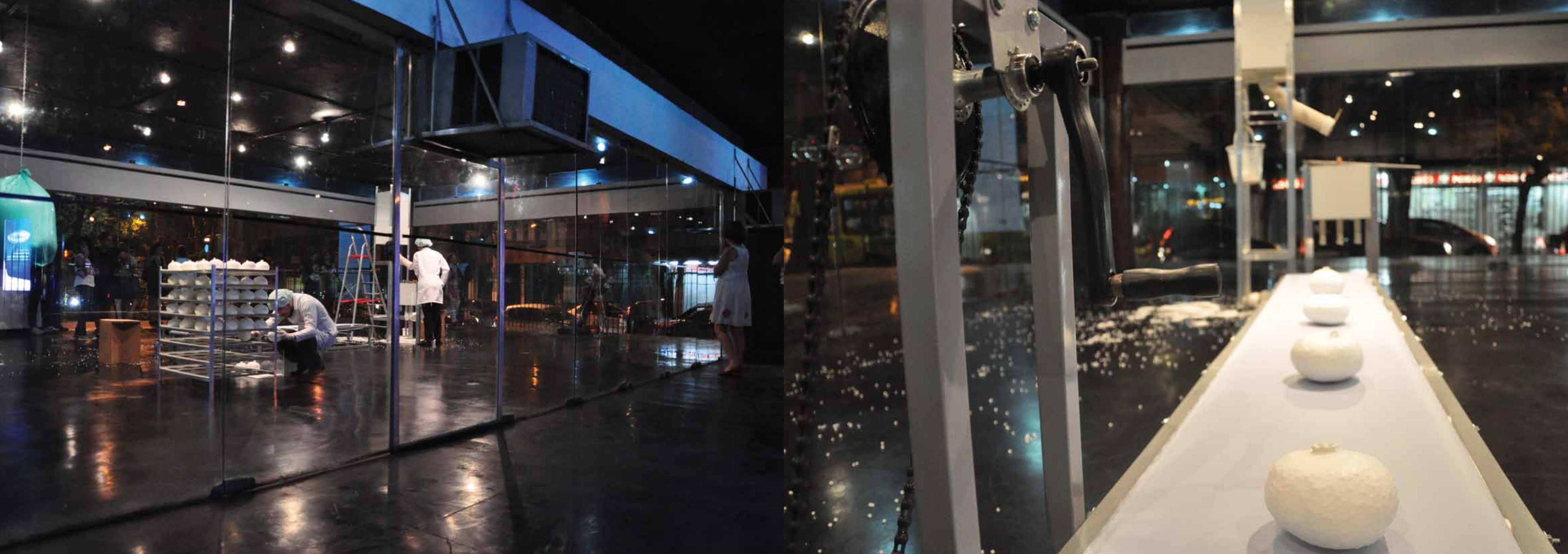




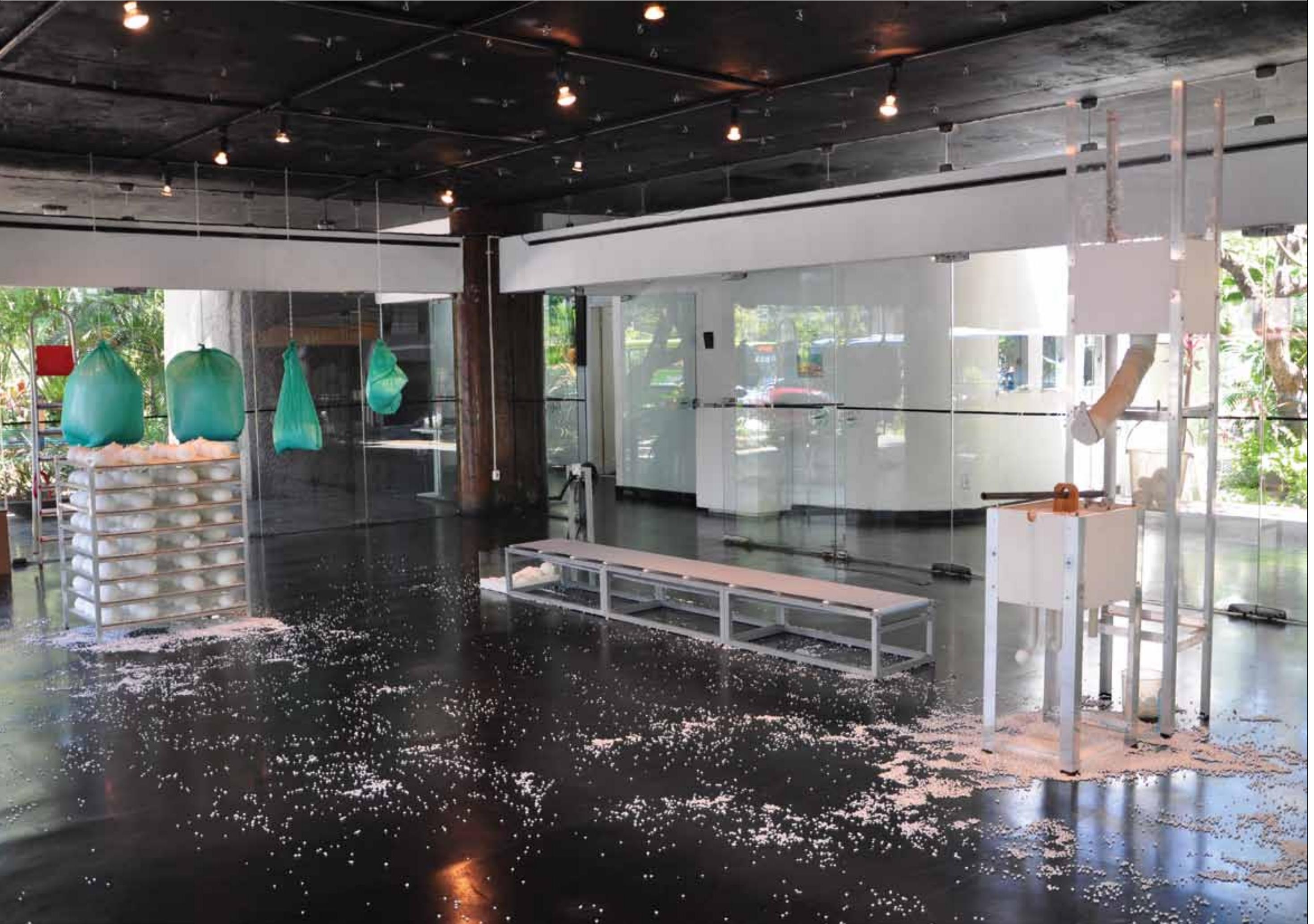

A sala de vidro e componente estrutural de "Incubadora". Com ela fechada, durante a de quem está fora dela, definindo o ato de observar do publico como um ato também constitutivo do trabalho. Nessa estrutura, o observar manifesta uma dimensão de controle e, nesse sentido, é tomado como um ato ativo. Por outro lado, essa estrutura poderia ser comparada também às vitrines e a seus modos de criar desejo em relação ao que está dentro, desejo que estaria associado à curiosidade levantada pela excentricidade da tecnologia em questão, e a seu produto, o balâo - ambos separas momentaneamente do público. Entro, no momento da performace, essa

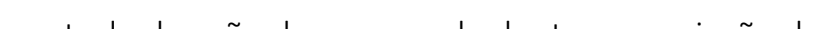
desejo nos corpos de fora.

Em "Incubadora", a produç̃oo a partir dessas máquinas anacrônicas acaba voltando uma "ha concentrado e firme, com movimentos contínus durante a operação das máquinas (nem rápidos, nem lentos), e postura ereta quando parado. Essas constâncias do corpo vão sendo marcadas $\mathrm{e}$ observadas em pontos da produção do objetto. O espacamento entre um balão e outro na esteira

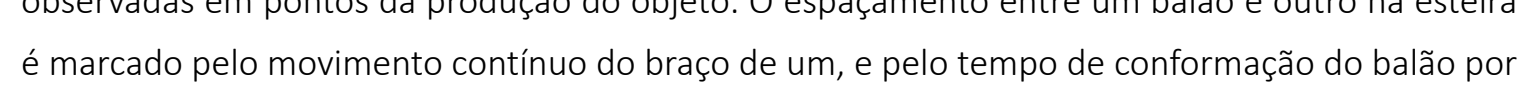
outro. 0 tamanho dos balōes é marcado pela extens̃̃o do movimento da alavanca da máquina e pela quantidade de subidas e descidas.

O circuito de açōes repetitivas parece criar uma similaridade entre essa experiência de corpo proposta para a performance e a experiência de corpo de operar máquinas em movimentos mecânicos repetitivos. A simplicidade da instrução de manter o corpo ereto, concentrado e constante, parece criar uma similaridade de experiencia entre o corpo de quem realiza a ação e os corpos em situaaçoes comuns no dia-a-dia. Na junção da instruçâa, com a ação repetitiva em tempo prolongado, esse corpo que poderia se entregar ao cansaço e realizar as açōes de forma mais relaxada, demonstrando esse cansaço, continua seguindo a instrução de se manter firme,

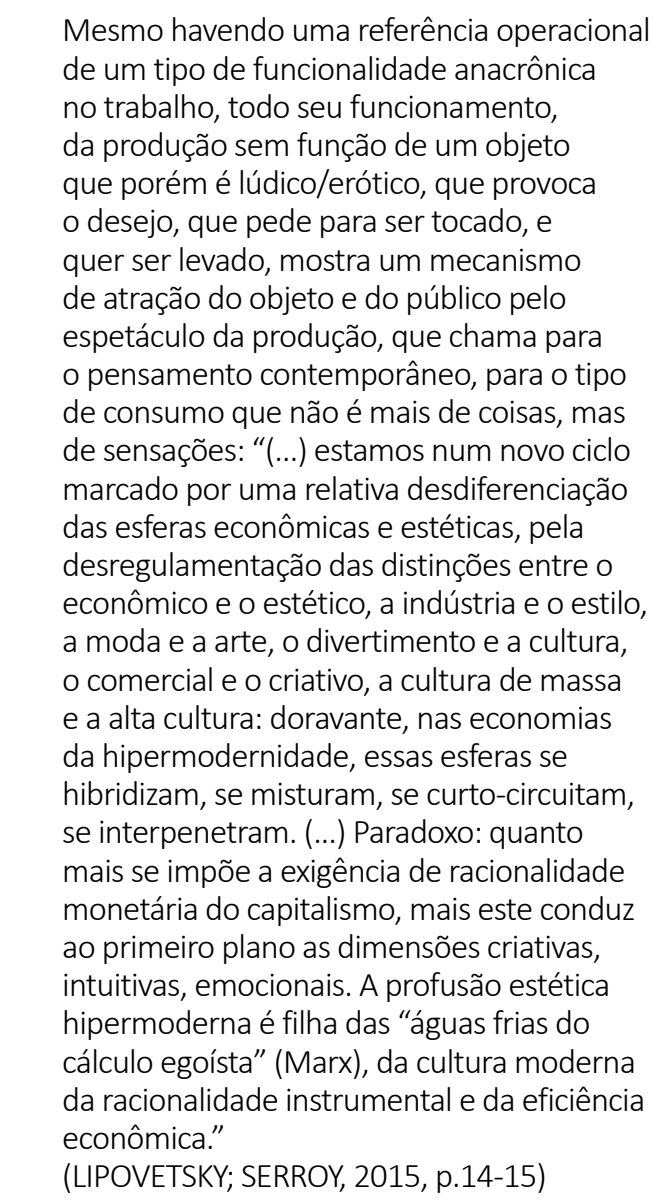


pego, levado, ou destruido. A experienncia do publico nesse espaço pode interferir numa percepçåa não apenas do objeto de arte, mas também do objeto tecnico e sua logica de funcionalidade, e da relação do corpo com a produçã̃o.

Entre a sala de vidro, os elementos da instalacąâ, os corpos que performam, os movimentos corporais, o público que observa, a produção dos balōes, e os próprios balōes cheios armazenados, outras imagens coexistem em movimento fluido e latente que ora tomam a frente, e ora recuum dando voz a mais imagens.

Aarte. A ciência A técrica. A fábrica. O laboratório. Otrabalho. A casa. O escritório. Avitrine.

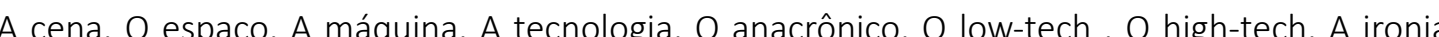

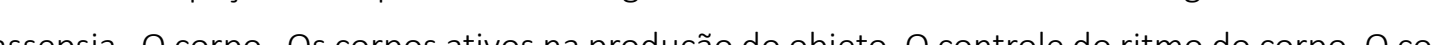

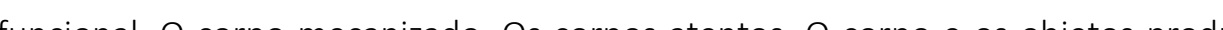

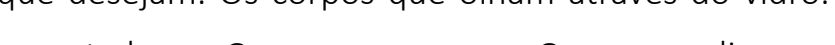

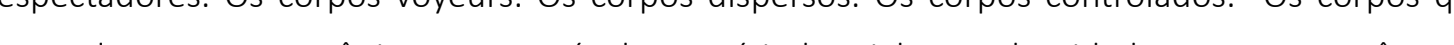

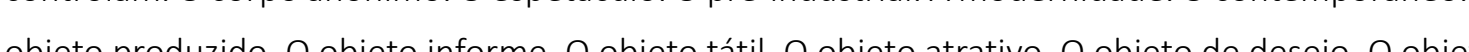
objeto produzida. 0 objeto informe. 0 objeto tall. O objeto atrativo. O objeto de desjjo. 0 obje de consumo. 0 objeto sem função. 0 processo sem função. 0 inorgânico. 0 orgânico. A máquina A interação com a máquina. 0 erotismo. 0 movimento corporal. 0 movimento repetitivo. 0 tédi O cansaço. 0 corpo exaurido. A distopia. O corpo que observa. Os corpos exauridos pelo ato de observar. O desejo pelo objeto. A ambiguidade. A criação. A proliferação. A homogeneização. A utopia. 0 lúdico. $O$ riso. $O$ insano.

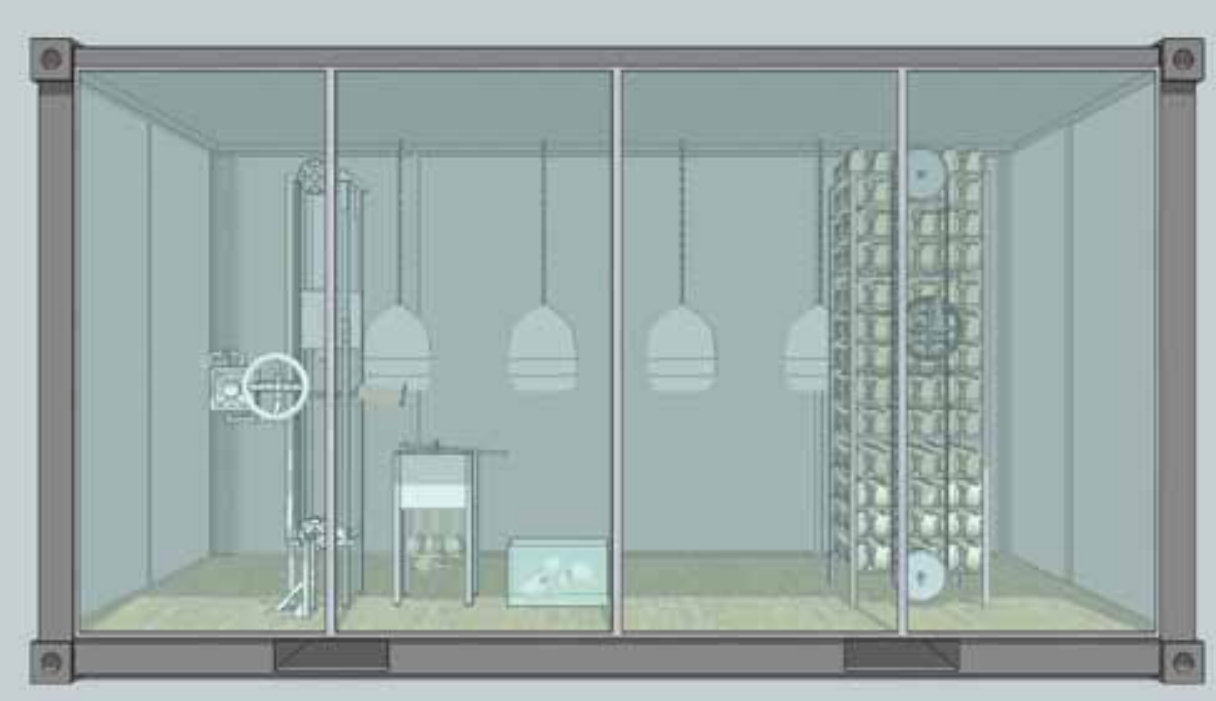

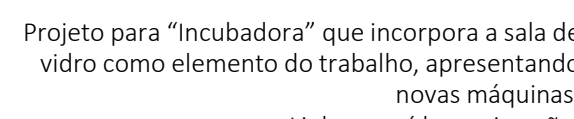

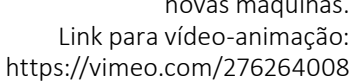

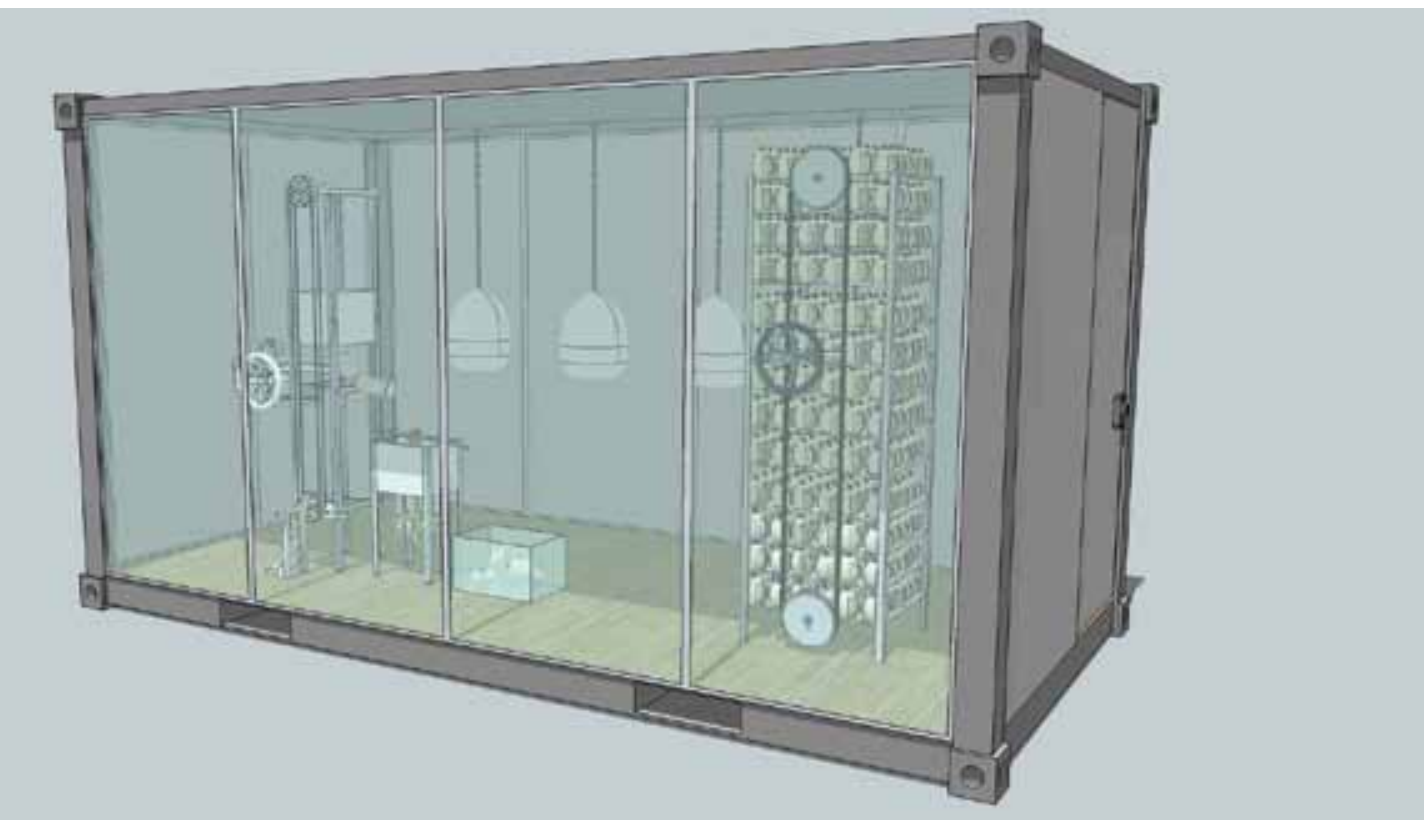



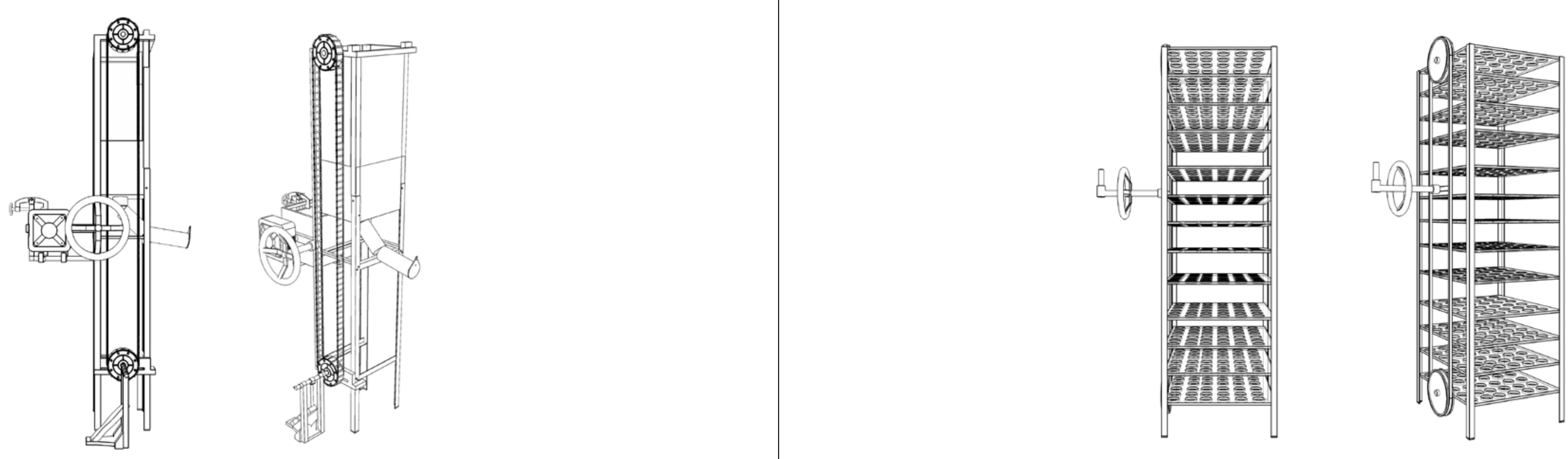


\section{II. corpo matriz}

Molde. Com os cabelos presos e um filme de PVC envolvendo a cabeça, deito o corpo em uma mesa com as costas viradas para baixo. Embaixo da cabeça, um apoio. Em cima do corpo, um tecido para proteger dos restos do procedimento. As mãos do outro passam um líquido oleoso sobre o rosto e depois selam os olhos com vaselina. Dois canudos são colocados no nariz. As mãos do outro vão jogando camadas cremosas de gesso sobre o rosto, debaixo para cima. Fecho a boca A visão escurece. A massa de gesso sobre o rosto faz com que o corpo não reconheça a execuç̧ão da expressão facial. Em estado cremoso, corpo e gesso se confundem. Com o tempo, o gesso vai mudando de textura e de temperatura, vai enrijecendo e ficando quente. Na medida em que endurece, fica claro o limite entre corpo e gesso. Durante cerca de 30 minutos, só respiro

O gesso endurece e é retirado pelo outro. Na placa, o formato côncavo do rosto deitado.

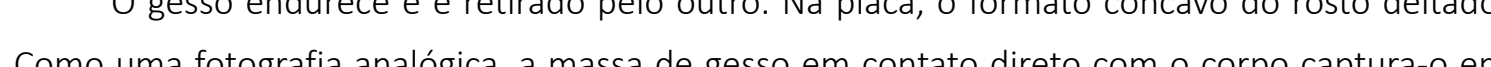

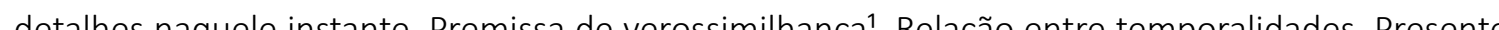

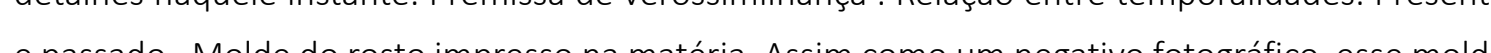

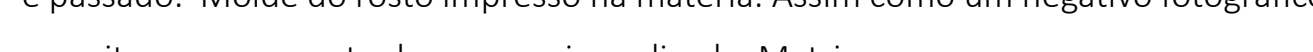

toé realizado para responder a uma proposiç̧ão feita em disciplina do doct torado em 2016. No exerćcicio de pensar uma segunda-pele, algo externo que me represente, parto para a idela de criar moldes do rosto, pensando o rosto como máscara². A materla gesso colocada por cima do rosto cria uma delmitaçăo entre espaço interno e espaço externo. Gera tensão. Para quem vive o procedimento, o gesso limita a comunicaçăo com o externo. Para quem está de fora, limita a comunicação e sua visualização completa do corpo

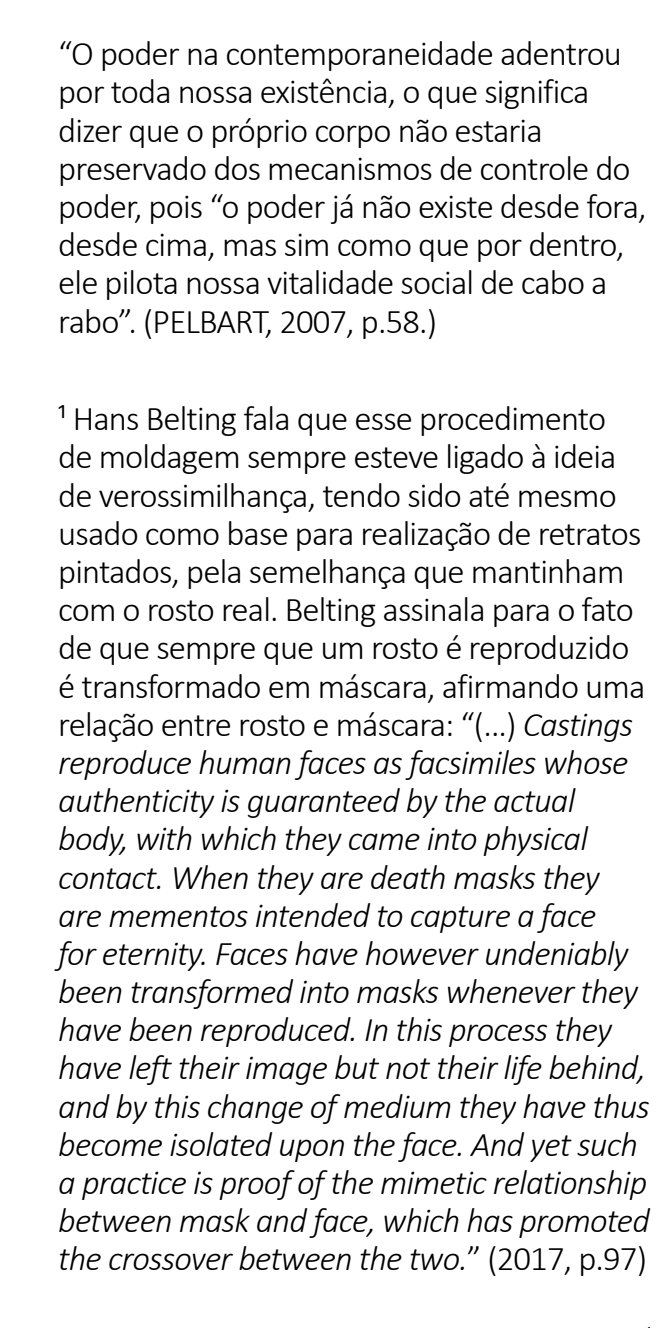




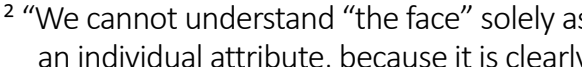

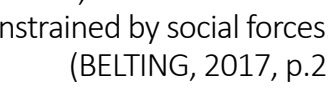
3 Para Belting, as máscaras mortuárias
na modernidade, exerceram um grande

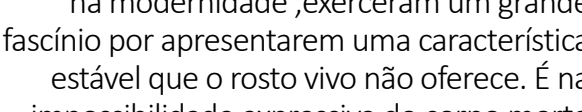

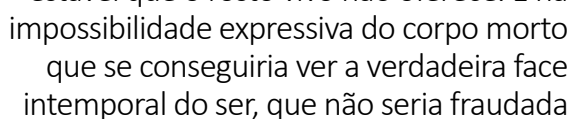
pelas expresssoes faciais que sempre
camuflame e escondem sua face autêntica (BELTING, 2017,. .78)
(1)

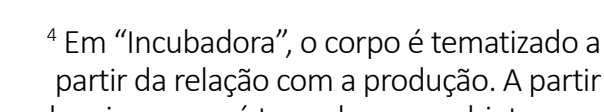

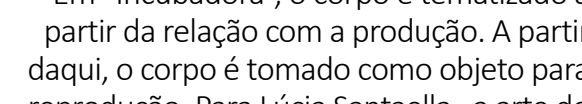

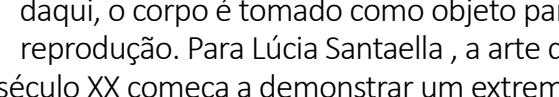

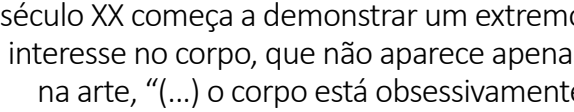
onipresente porque ele se tornou un
dos sintomas da cultura do nosso tempo

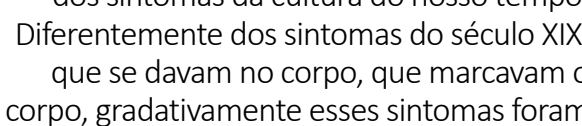

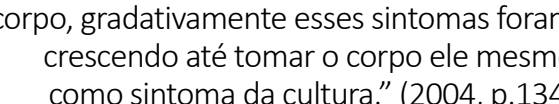

Vivencio a massa de gesso sobre o rosto. Sensaç̧oes de claustrofobia, enclausuramento. De certa forma, parece haver um espelhamento dessa experiência interna, de quem realiza o procedimento no próprio corpo, para quem está fora dele. A imagem mental que o procedimento gera, essa criada pela pessoa com uma massa de gesso por cima do rosto respirando pelos canudos, suscita analogias que parecem transitar entre aflição, medo, clausura, morte. A ideia da morte surge também por causa do procedimento que está associado às máscaras mortuárias ${ }^{3}$.

Entre 2016 e 2019, realizo o mesmo procedimento diversas vezes, inicialmente para criaçăo de máscaras, com a execução de expressões differentes em cada ocasião. De cada uma delas, um molde differente do rosto é impresse. A partir da realizacão do procedimento, dois caminhos do

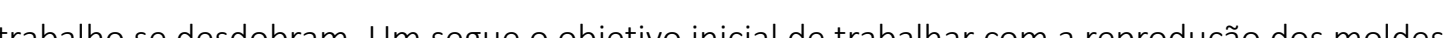
rosto. Outro, tensiona a potência da imagem gerada pelo procedimento.

corpo como molde, origem e meio4

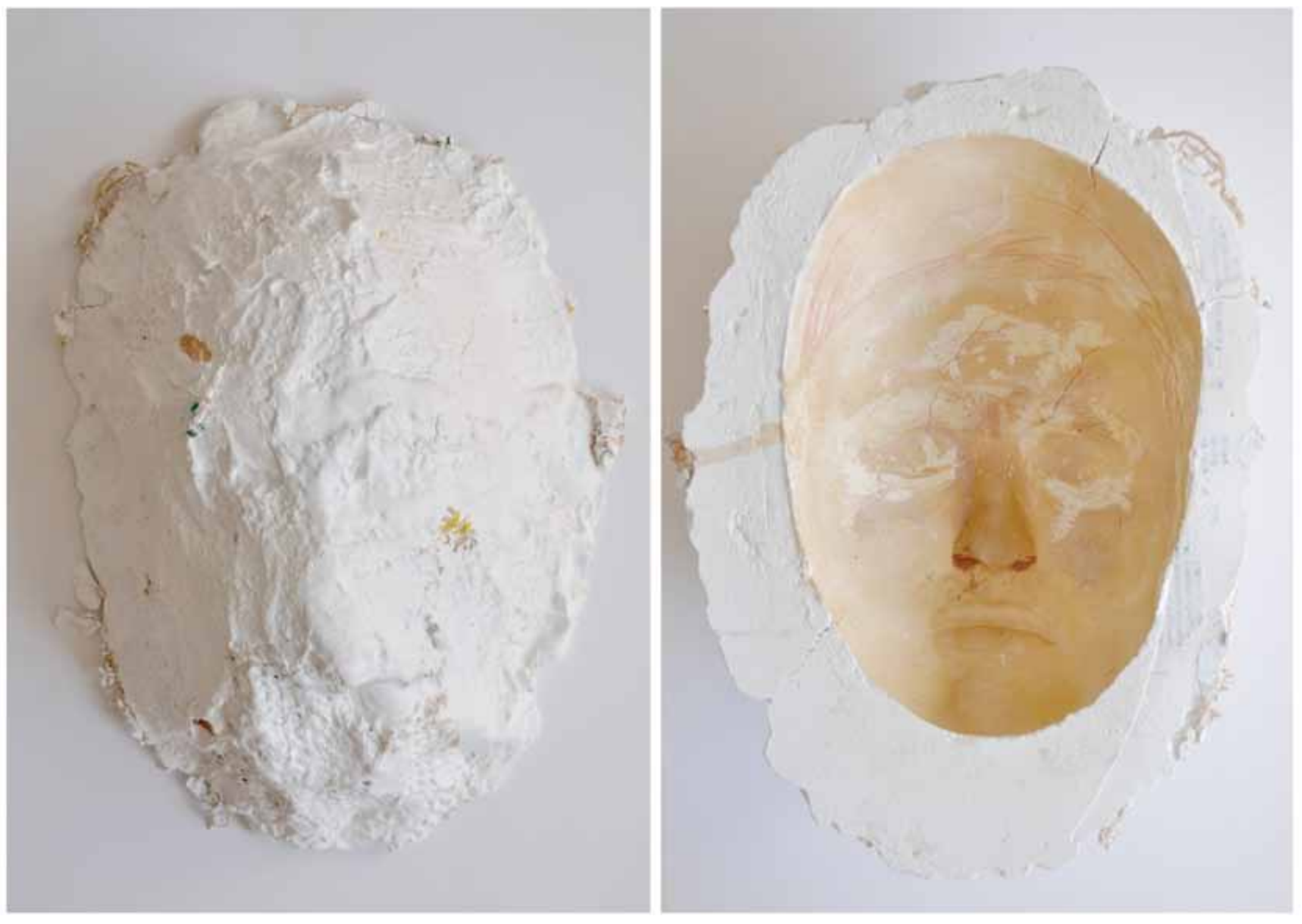




\section{“IMAGEM”}

"Imagem" e uma proposta de performance pensada a partir do procedimento de moldagen do rosto, realizada de forma experimental em outubro de 2019, 3 anos depois da primela moldagem, numa exposição coletiva na Casa da Luz.

A Casa da Luzé um espaço cultural que ocupa uma antiga hospedaria de São Paulo, datada do século XIX, Iocalizada ao lado da Estaç̃o da Luz O prédio tem 3 andares e diversos ambientes ale mantêm características originais do antigo locel, com piso de taco de madeira escura restarito. sistema de iluminacão novo por calhas independente, e teto antigo de vigas de madeira aparente.

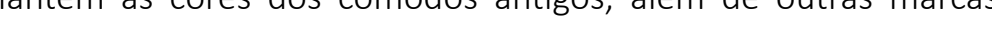
Aç̃o Na abertura da exposiço, em uma das salas do 20 andar da cose, una

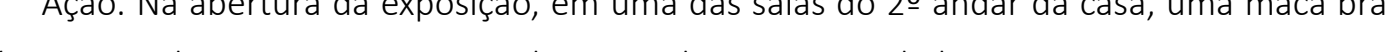
está posicionada ao centro. Em Cima da maca, derto o corpo de ban ga para cima com as pernas

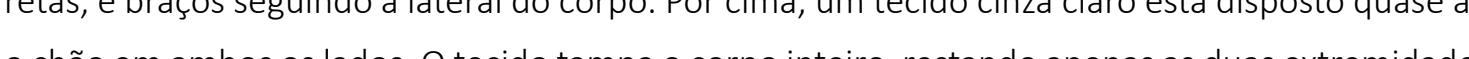
o châo em ambos os lados. O tecido tampa o corpo inteiro, restando apenas as duas extremidad s. pes e cabeça. As roupas estâo justas ao meu corpo. 0 tecido o tampa e delinela bem sua forma. Os pés para fora pretendem assinalar para a existência do corpo. A cabeça está fechada pela massa de gesso, de onde se pode ver 2 canudos grossos de plástico (listrados de vermelho e transparente) média de 3 centimetros em toda a extensão do rosto. Sua textura é bastante irregular, com marcas do gestual de feitura. Uma chapa de compensado fina ampara a peça e se apoia no corpo. Embaixo da cabeça, uma toalha.

Nessa ocasião, o procedimento de moldagem do rosto é realizado da mesma maneira descrita acima, mas acontece antes do público chegar. Os materiais para moldagem são retirados.
O público só vê o resultado da massa de gesso sobre o rosto. A performance se realiza na relação entre meu corpo, 0 que esta por cima dele, a ação de restar imovel prolongada no tempo e o público. A disposiçăo dos objetos no espaço pensa ainda a Imagem fotográfica da ação, para o público posterior.

№ acão, depois de estar com a massa de gesso no rosto, sigo a instrução de manter r respiração normal, o corpo relaxado numa mesma posicão, e de evitar movimentos bruscos O corpo preserva as mãos ao lado na maior parte do tempo, deve se manter da mesma forma

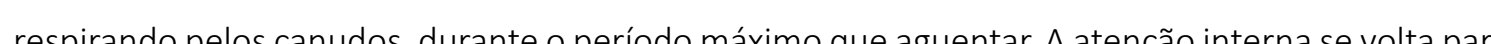
0 ato de respirar Na duraç̃o, mesmo que já tenha acostumado, o corpo oscila entre relaxamento e aflicăo. A exaustão marca um limite para meu corpo, e tensiona a relação entre ele e os outros corpos ${ }^{5}$. Um único gesto se alonga no tempo e reforça possiveis imagens e analogias já inerentes ao procedimento.

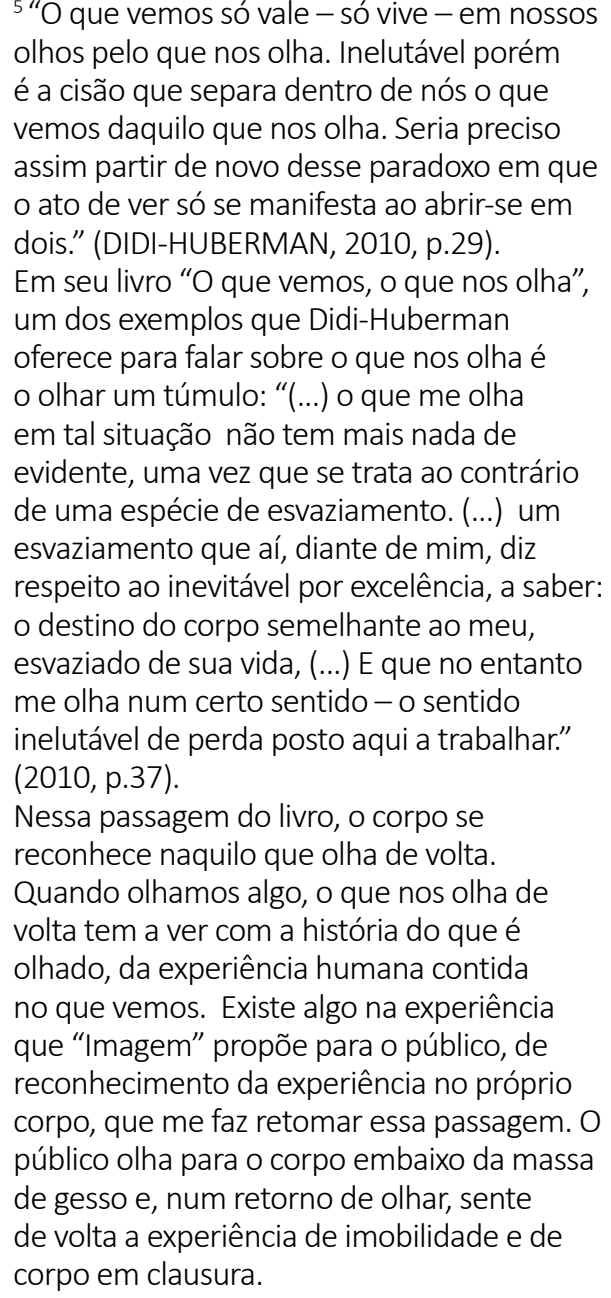




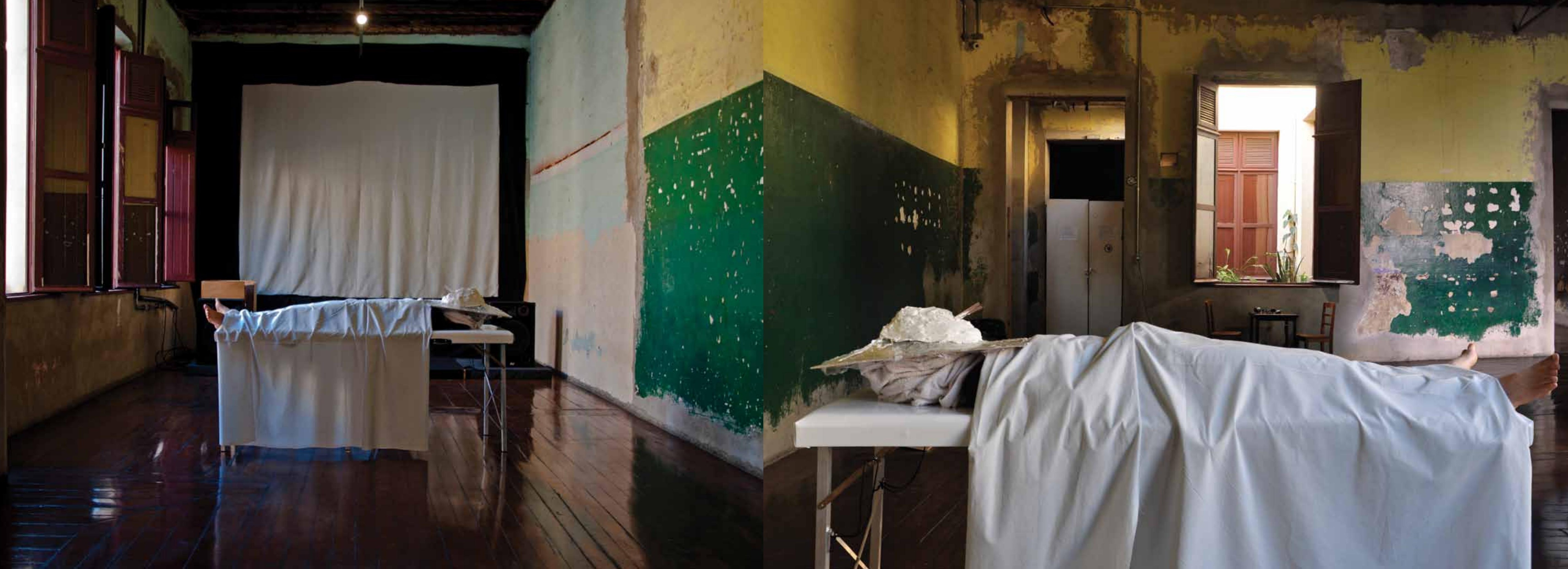



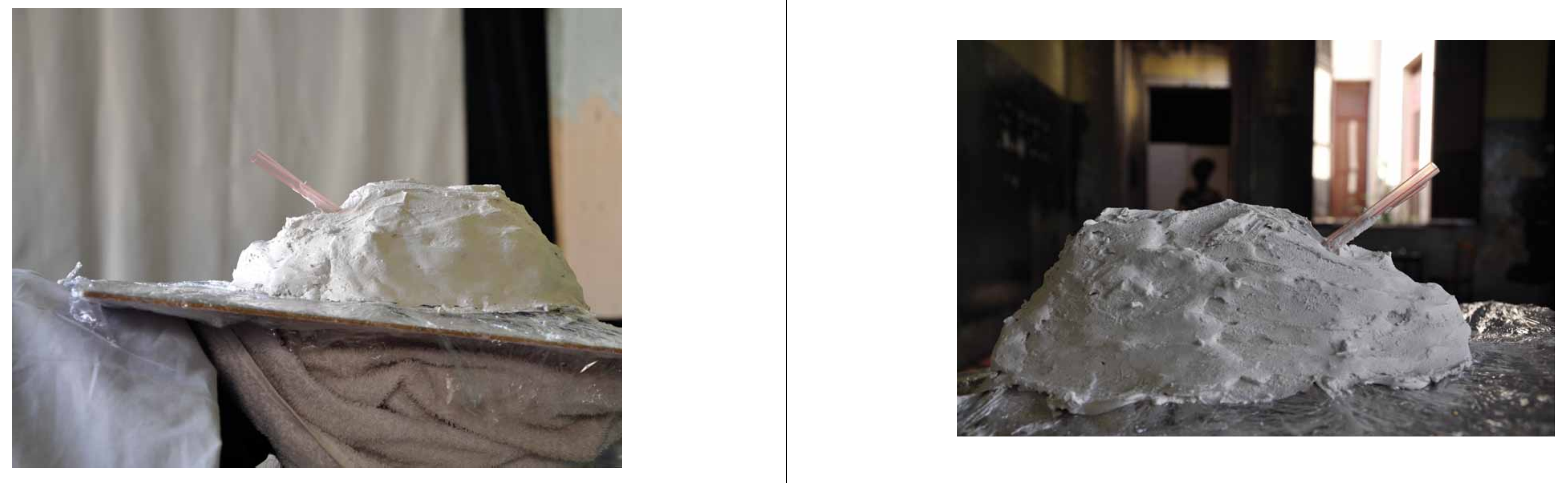
. $\quad$ corpo inerte e o corpo do público se afetam. Meu corpo imobilizado e vedado pela massa . de gesso tem a expectativa sobre os possiveis gestos desses outros corpos. O público entra na sala

vê um corpo sob objetos, ou objetos sobre algo, caso não tenha reconhecido imediatamente a
- existência do corpo. A ação não sugere interação. O público se afeta pela imagem desconfortável do corpo inerte. Caso se interesse, pode chegar perto e identificar melhor a existência do corpo que, apesar de parado, realiza os movim veres, leves movimentos de ajustamento de postura. A atencão externa se volta para o ato de ficaçoes feitas.

O distanciamento parece ser também uma boa fruição da experiência. Na inatividade observado à distância parece fixar uma imagem nos olhos de quem vê, retoma algum tipo de experiência daquelas fotografias que exigiam que o corpo ficasse na mesma postura por longos períodos. Inatividade aparente do corpo que gera imagem. O corpo como meio para produção de imagem

Ao circular a exposiçãa, passar diversas vezes pelo mesmo ponto, o público vê uma mesma imagem em todos os momentos. Repetição. Na inatividade aparente, o corpo também pode ser tomado como mais um objeto do espaço

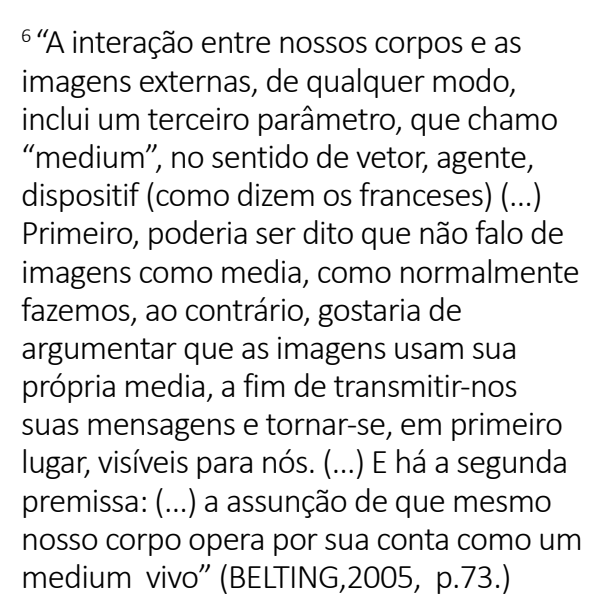




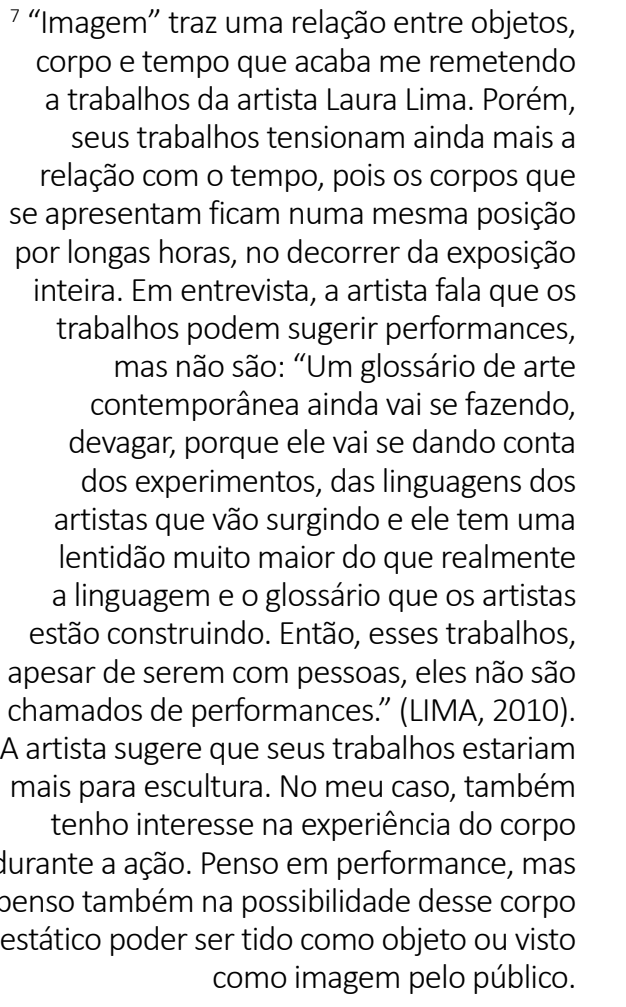

1.Representação ou reproduçăavisuat le de

2.Representação de um objetode de cultito of

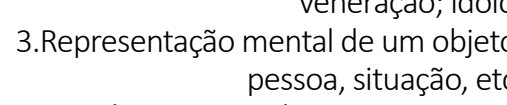

4.Fig. Aquilo que reproduz, imita ou evoca alguém;
5.Figura, metáfora:(..)
(LAROUSSE, 2001, p.526)
Procedimento e espaço articulam tempos. O procedimento de moldagem estabelece uma relação entre passado e presente do corpo moldado. Visa marcar numa matéria (gesso) um tempo de outra matéria (corpo). 0 espaço com todas as suas marcas de temporalidades diferentes se vincula ao procedimento nesse ponto. A ação alongada no tempo provoca ainda mais a imagem de clausura orientada pelo procedimento.

Ao fim da ação, quando já nãoé mais possivel suportar o peso da placa de gesso, e a respiraçăa pelos canudos, retiro o molde do rosto, me levanto e saio do espaço. Nessa ocasião, a ação dura um pouco mais de 2 horas. Os resquícios da performance não restam no local, mas uma fotografia é pensada para ficar na exposição, em outra sala. Em exposição, a fotografia mostraria um local da mesma casa, mas em outro tempo. Geraria dúvida se aquilo que mostra aconteceu durante a exposição ou se foi feito para a foto. Apesar da dúvida, pretende trazer mais uma camada de deslocamento, reforcando características que procedimento e espaço trazem em si. Sobreposição de tempo e espaço.

titulo "Imagem" faz uma primeira menç̧ão ao ato de criar uma representação de si a partir do procedimento de moldagem do rosto, jogando com a ideia da construçãa da própria imagem. Ao mesmo tempo, trabalha com outro sentido da palavia, o da representaçáo do objeto de culto (tendo o rosto como motivo dessa representação). "Imagem" pensa ainda no estado inerte do corpo em performance que acaba fixando uma imagem aos ollos de quem vê. Por último, também da construção da imagem fotográfica que ficaria em exposição?

0 ato de se representar como ato de se construir. A construção da imagem de si em relação à construção da imagem de culto. O olhar do outro como participante na construção da própria imagem. 0 ato de se representar como ato de fixação e paralisação do tempo.
"CAPA" é uma fotografia performada ${ }^{8}$ realizada em 2017 - um primeiro desdobramento da reprodução dos moldes do rosto descrita no inicio do capitulo.

Sua imagem mostra a parte superior do corpo centralizado em um cenário vazio de fundo branco. A parte inferior do corpo não é mostrada. Antebraços e mãos também não aparecem. Os cabelos estão penteados e jogados para trás. Nela, visto uma blusa de botão branca abotoada e uma máscara de látex no tom da minha pele. A máscara é feita a partir do molde do rosto.

A fotografia segue parâmetros das Traje formal. Parâmetros formatados. Padronização. Neutralidade. Controle de corpo e expressão. O corpo. A máscara. A fotografia. Camadas de tempo em sobreposição. O corpo traz a mesma temporalidade do momento do clique fotográfico. A máscara, uma temporalidade anterior à do corpo eà da imagem. A fotografia fixa na imagem corpo e máscara. Cria uma terceira temporalidade. O tempo do corpo. 0 tempo do corpo na máscara. 0 tempo do corpo e da máscara na fotografia. O rosto como máscara ${ }^{10}$.

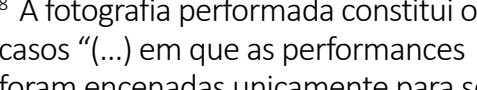
loram encenadas unicamente para serem
fotografadas ou filmadas e que nãotiveram existência anterior como eventos autônn
apresentadados a platelias. Oe espaço do

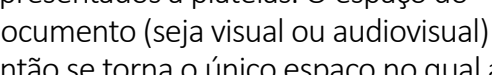
performance ocorre,"
(AUSLANDER, 2013, p.5)

9 A necessidade de identificacăo dos
individuos torna-se necessária com as sociedades de massa, momento em que

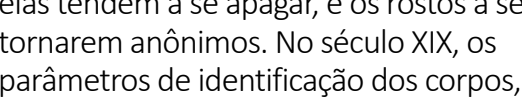

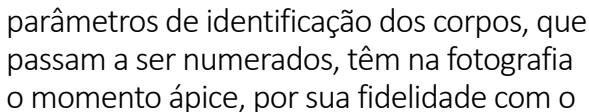
O momento áice, por sua
real." (COURTINEF; ;AROCHE,
1988, p.220- 2.225 )

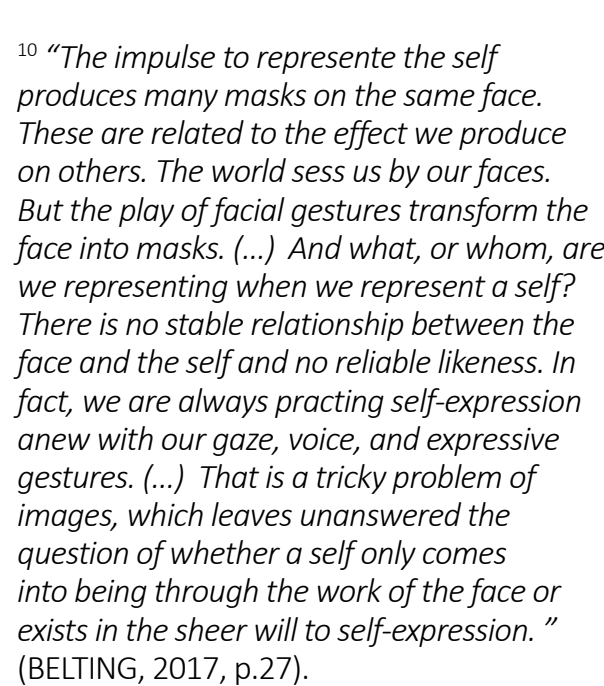




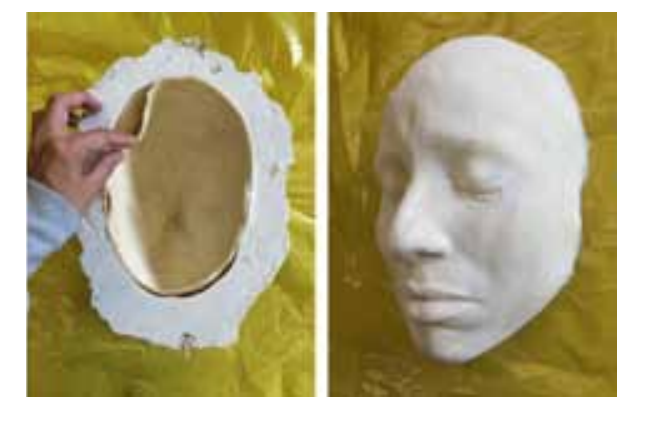

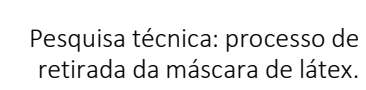

"1"Mesmo imagens de derivaçãotecnológicac
como a fotografíca e a video-eletroñica ainda

são elaboradas a partir de uma realidada
visivel précistente integrand portanto

visivel pré-existente, integrando, portanto,
universo da especularididade."FABRRS, 1998 )

A mascara feta em latex escurece em contato com o ar e retoma o tom da minha pele. detalhes da feição. Sendo tirada a partir do molde do rosto, a máscara traz uma primeira tentativa de marcar fidelidade entre corpo e objeto resultante. A fotografia reafirma essa vontade". Ambos os meios carregam a mesma premissa de verossimilhança. Porém, na medida em que visto uma máscara de mim, me mostro e me escondo ao mesmo tempo. Juntas, máscara e fotografia criam um duplo distanciamento do corpo que representam. Imagem e corpo fotografado não coinciden. O rosto é mascarado por uma série de padrões de comportamento, modos de conduta que

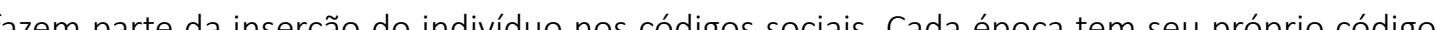
oficial da identidade do indivíduo na vida social Forma de representaç impregnada com a ideia de identificação e reconhecimento. A busca da identidade na fisionomia A imagem vai sendo construída entre corpo, máscara, cenário, vestimenta, posturą, enquadramento, iluminação, mesmo que muitos desses dados pareçam inexistentes - ou estejam neutralizados pelo uso de um código que se pretende invisivel ou neutro.

Ajusto câmera e luz. Sento meu corpo em uma cadeira posicionado a frente de uma parede branca. Vários cliques são dados. Observo as fotos. Marco o enquadramento do corpo na imagem. Explico para o outro os parâmetros ideais. Reposiciono corpo. Ajusto cabelo e roupa. Visto máscara. Mantenho-me ereta. 0 outro verifica os parâmetros. Ajusto postura. Levanto o rosto. 0 outro clica. Autorrepresentação realizada a dois.

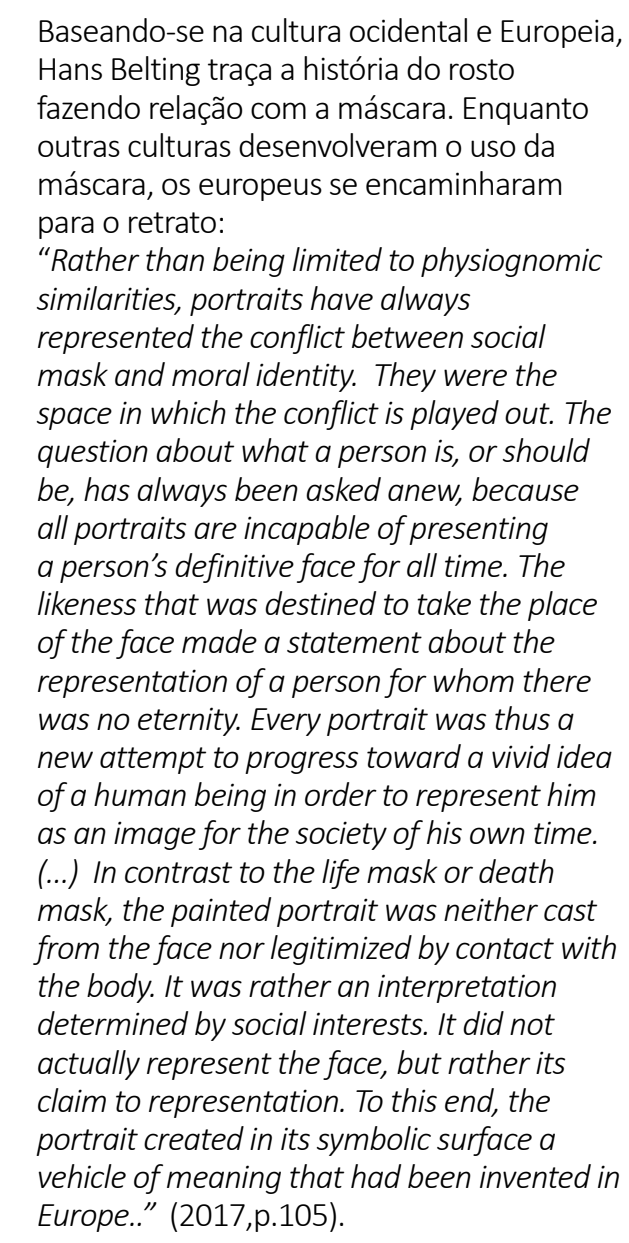




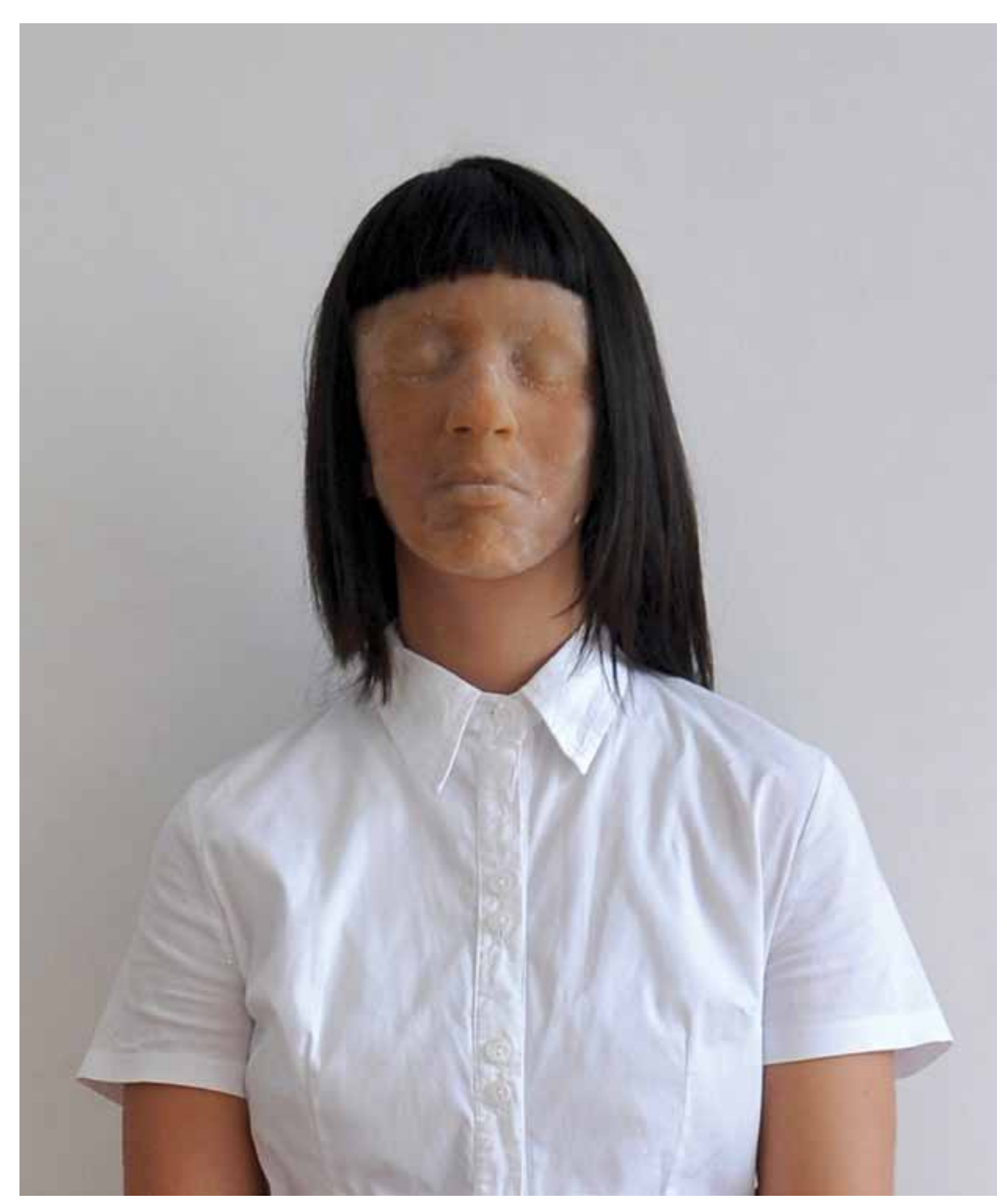

$O$ ato de se representar associado ao outro a quem se representa.

A autorrepresentaçăo figura entre os generos das artes. A partir da popularização dos aparelhos fotográticos, dos celulares de multiplas funçoes, da internet e das redes sociais, a autorrepresentação ganha outra dimensão. Deixa de ser uma prerrogativa do artista, e passa a figurar um ato socialmente investido diariamente. Mudança dos costumes de época. Vida privada

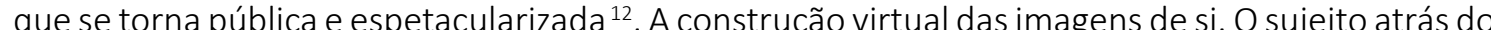
Suijeito e imagens do suipito. Disso

a comunicaçăo de massa já estiveram entre os principais responsáveis pela criação de padrôes de beleza e de comportamento. Padrões observados, assimilados, reproduzidos. Há quase três décadas, as redes sociais também interferem nesses direcionamentos criando outras formas de interação que vão ajudando a cunhar o imaginário de uma época.

"CAPA" inicia a série de trabalhos "APAGAMENTO" (2017), que aborda a representação de si, fazendo analogia às ideias de revelar, esconder e apagar. Seu titulo se refere àquilo que veste (como a roupa), aquilo que encobre (cobertura), aquilo que protege, aquilo que abre e fecha (como a capa de um livro), àquilo que oferece superpoderes (como as capas dos super-heróis).
12" "Háu uma pista, entẫo, para compreender
of fascinio suscitado por essa muttidão de historias minuisculas to todos essess micricro-

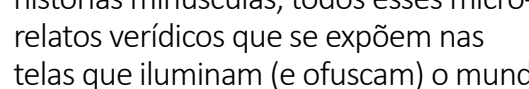

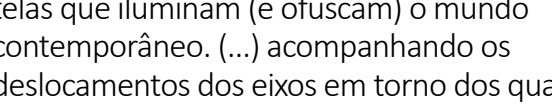

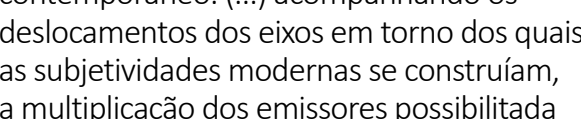

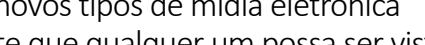

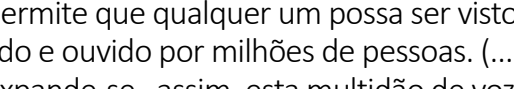

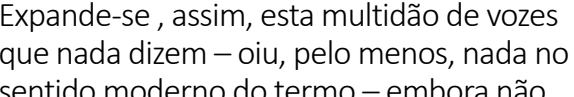

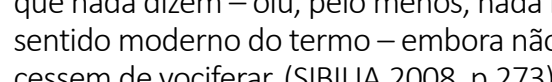




\section{"SIM, NÃO, TALVEZ"}

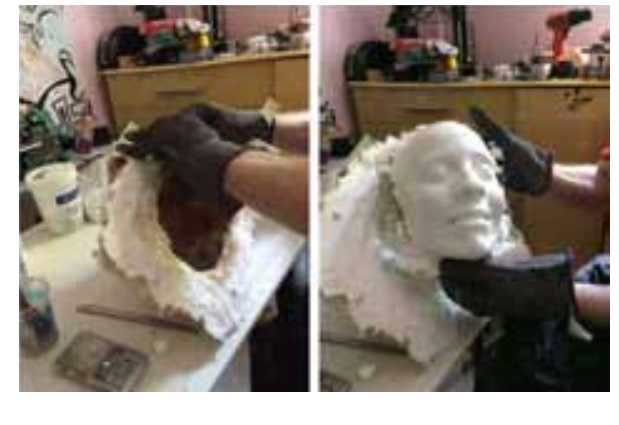

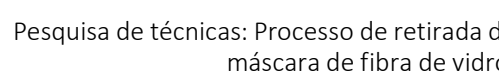

$:): 0: 0: 0: 0$

(2) (-) (2) (-) (-)

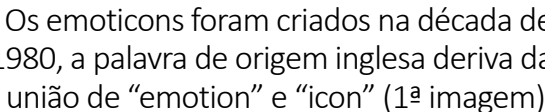
Já os emojis foram criados na décad

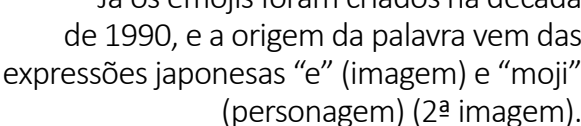

Trata-se de um video realizado em 2018 a partir de fotografias performadas. Sua imagen

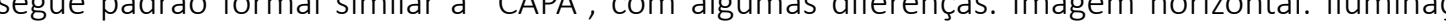
controlada de estúdio. Corpo centralizado na imagem com maior espaçamento nas lateras. Máscaras de fibra de vidro feitas a partir dos moldes do rosto. Cor branca que evidencia máscara Expressões definidas. Descolamento entre corpo e máscara na imagem. Imagem que deixa dúvida entre fiç̧ão e realidade.

O vídeo se realiza a partir de 53 imagens que, ligadas em sequências constantes de tempo

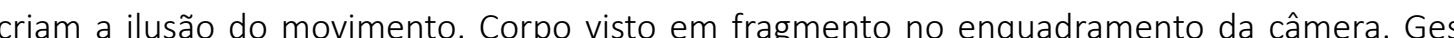

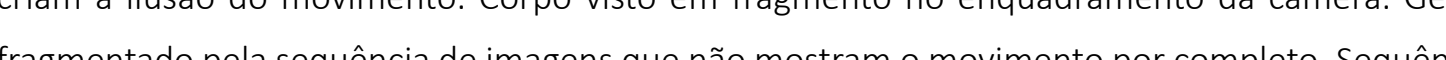

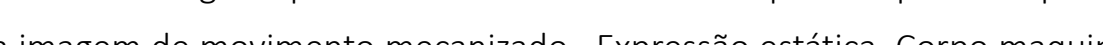
Manequim. Ironia.

O vídeo mostra a parte superior de meu corpo girando frontalmente de um lado para o outro. Mãos e braços não aparecem. A cada virada, uma máscara se apresenta. A máscara feita em fibra de vidro é branca, ríida e marca os traços gerais da expressão, sem marcar muitos detalhes do rosto. É feita num aspecto mais artificicial, sem retomar os tons de pele, apesar de remeter

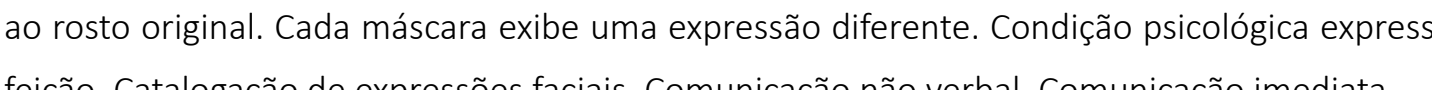
feição. Catalogação de expressões faciais. Comunicaç̃̃o não verbal. Comunicação imediata.

A expressão facial e os gestos corporais funcionam como códigos de comunicação que se somam à linguagem verbal. Além de facilitar a comunicação, tornam-na mais rápida. Na comunicação escrita, existem elementos que assumem o mesmo papel: emoticons e emojis 13 . 0 uso desses ícones foi se tornando cada vez mais recorrente nos diälogos virtuais. Simplificação da linguagem. Velocidade de comunicação. Modo de expressão dinâmico, superficial, de rápida absorção, leve, divertido, informal

Muitos dos ícones partem das expressões e gestos corporais para seu desenho, numa breve catalogaçao de gestos, expressões faciais e corporais. A comunicação se utiliza desse catálogo de ícones. Depois de seu uso, os icones retornam ao corpo ressignificados. O corpo que volta a expressar o gesto, expressa agora a emoção e o significado apreendido do icone.

O corpo informa a criação do icone. O icone ressignificado pelo uso informa o gesto corporal. O ciclo vai se repetindo para criação de novos ícones, onde o corpo vai sendo retomado para depois reproduzir novamente o ícone.

Volto-me para uma série de emojis mais comuns de rostos traduzindo-os em expressōes faciais. Proponho criar um conjunto de imagens estereotipadas de emocões rapidamente identificáveis. Moldo o rosto. Crio máscaras. Visto.

Ajusto a câmera. Posiciono o corno e justo os parâmetros. Escolho enquadramento, A ir evoltar, mantendo o exc

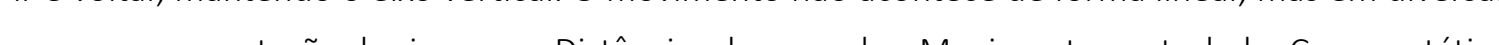

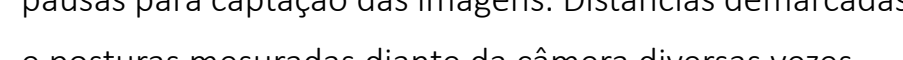

Vestida com blusa de botão e máscara, posiciono o corpo ereto, mantenho os ombros abertos, o pescoço e o queixo levantados. Posiciono o corpo para a camera com o lado direto em perfili. O outro faz pequenas correçoes de postura e parametros. Seguro a respiraçăo. 0 outro clica. Mantenho a postura e giro o corpo levemente para a esquerda, tentado manter o eixo da coluna sem movimentar. Posiciono o corpo para a câmera. O outro faz correções. Clica. O mesmo gesto val se repetindo até que o corpo esteja com o lado oposto em perfil para a câmera. Mudo a máscara. Arrumo cabelo e roupas. Posiciono o corpo de perfil com o lado esquerdo para a câmera. Tento manter o eixo da coluna no lugar. 0 outro corrige postura e outros detalhes. Clica. Essa série de movimentos de ida e volta horizontal, mantendo o eixo vertical fixo, vai se repetindo mais de 50 vezes ${ }^{14}$.

O corpo diante da câmera. As açoes repetitivas de virar, arrumar a postura, respirar e fixar. O clique. O controle da postura. O controle do movimento. O controle da câmera sobre o corpo.

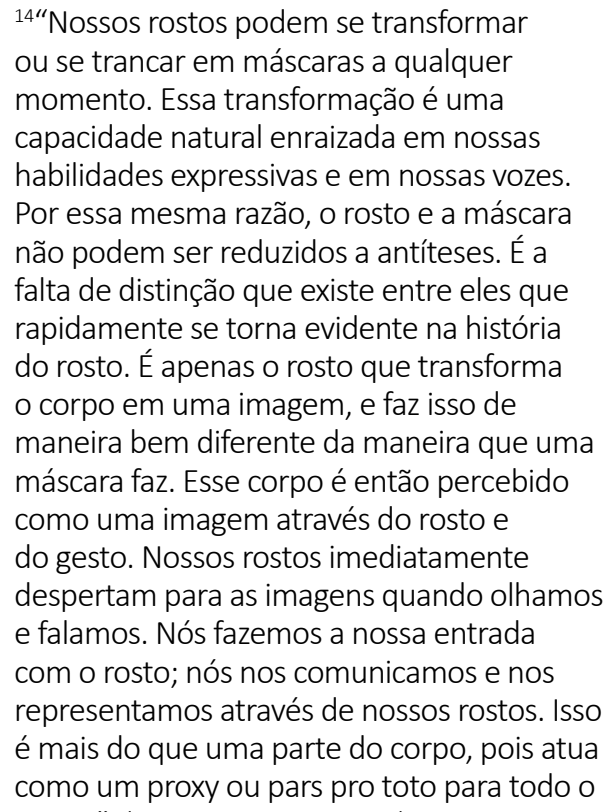

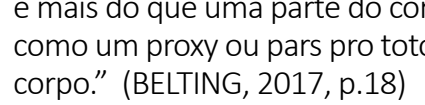

Link para vimeo: hthps://vimeo
com/253838085 
a 
is "Essa interacăo de dois meios subverte
intencionalmente e desestabiliza o caratter de indice da fotografia. (...) Somos ou pegos a apreciar a ambiguar referênciac cruzad
Aambiguidade, paradoxalmente, auxilia entiatzar um meio ne evidència do out.

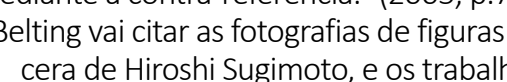
de Cindy Sherman em que simula stills de
filmes que não existem. Eu incluo também

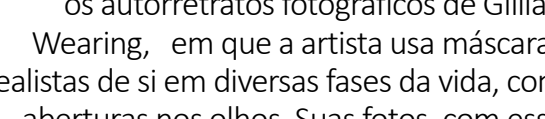
sobreposiçăo de meios e temporalidade

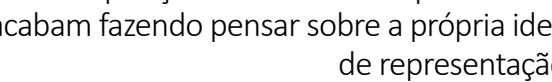

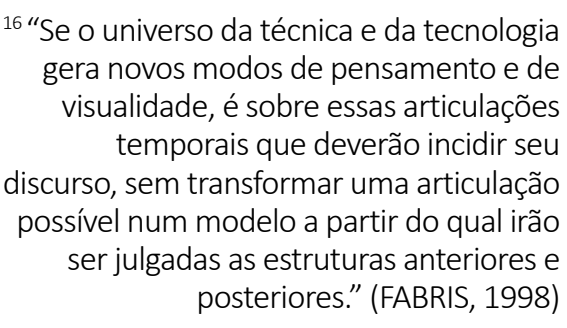

As imasens fotográficas condizem com os acontecimentos que mostram. Observo as diversas imagens digitais realizadas. Seleciono. Distribuo uma a uma lado a lado no computador. Estabeleşo o mesmo tempo entre elas. Crio uma sequência que não corresponde à sequência de açōes. Em vídeo, os movimentos pausados do corpo de ir e voltar têm uma linearidade que não condiz com os movimentos realizados pelo corpo para a camera fotografca. A sequencia cria a

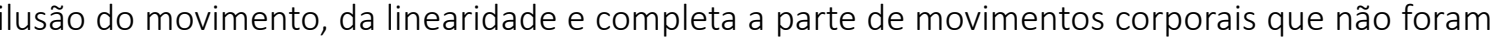
realizados. O video cria um tipo de movimento corporal artficial que náo existe no corpo natural. Montagen. Simulaçăa de movinanto. Simulaçáa de acontectmento. Descolamento de corpo e máscara. Descolamento de movimento corporal e movimento do corpo em video. Processos diferentes de construção da imagem fotografica e da do video. Analogia da foto e simulação do vídeo ao mesmo tempo ${ }^{15}$.

Dtrabalho val se constituindo num hibridismo de meios e em camadas, a partir de técnicas manuais e tecnologias digitais, técnicas mais antigas (como a moldagem do rosto), técnicas mais recentes (como os moldes de silicone e as máscaras de fibra de vidro) e novas tecnologias (como a fotografia e o vídeo). Enquanto a fotografia digital tem uma temporalidade do instantâneo da luz e uma relaç̃o com as possibilidades de manipulaç̃o virtual da imogem, a máscara produzida

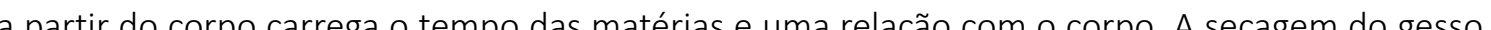
A catalisaça do silicone Arividez da fibra de vidro. Os detalhes do corpo na matérí Assim como

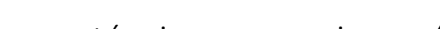

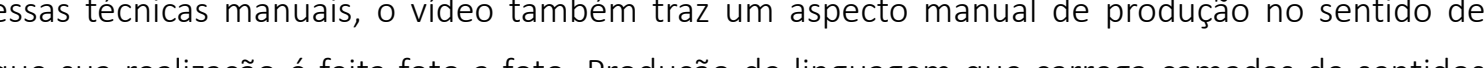
que sua realizaçäo e feita foto a foro. nroduçá de linguagem que carrega camadas de sentidos

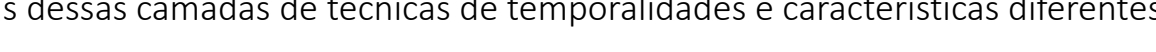

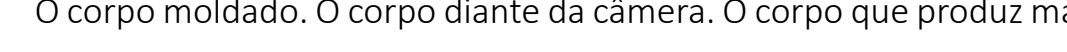
o video. Instanclas em que o corpo se relaciona com a produção do trabalho.

Otitulo do trabalho, "SIM, NÃO, TALVEZ", se refere à simultaneidade ambiguua das duas aç̧ōes que aparecem repetidamente em vídeo: o movimento lateral de ir e voltar do corpo no mesmo eixo vertical, num gesto de negativo, e a mudançă de máscaras marcando expressóes vvadds a cada virada.

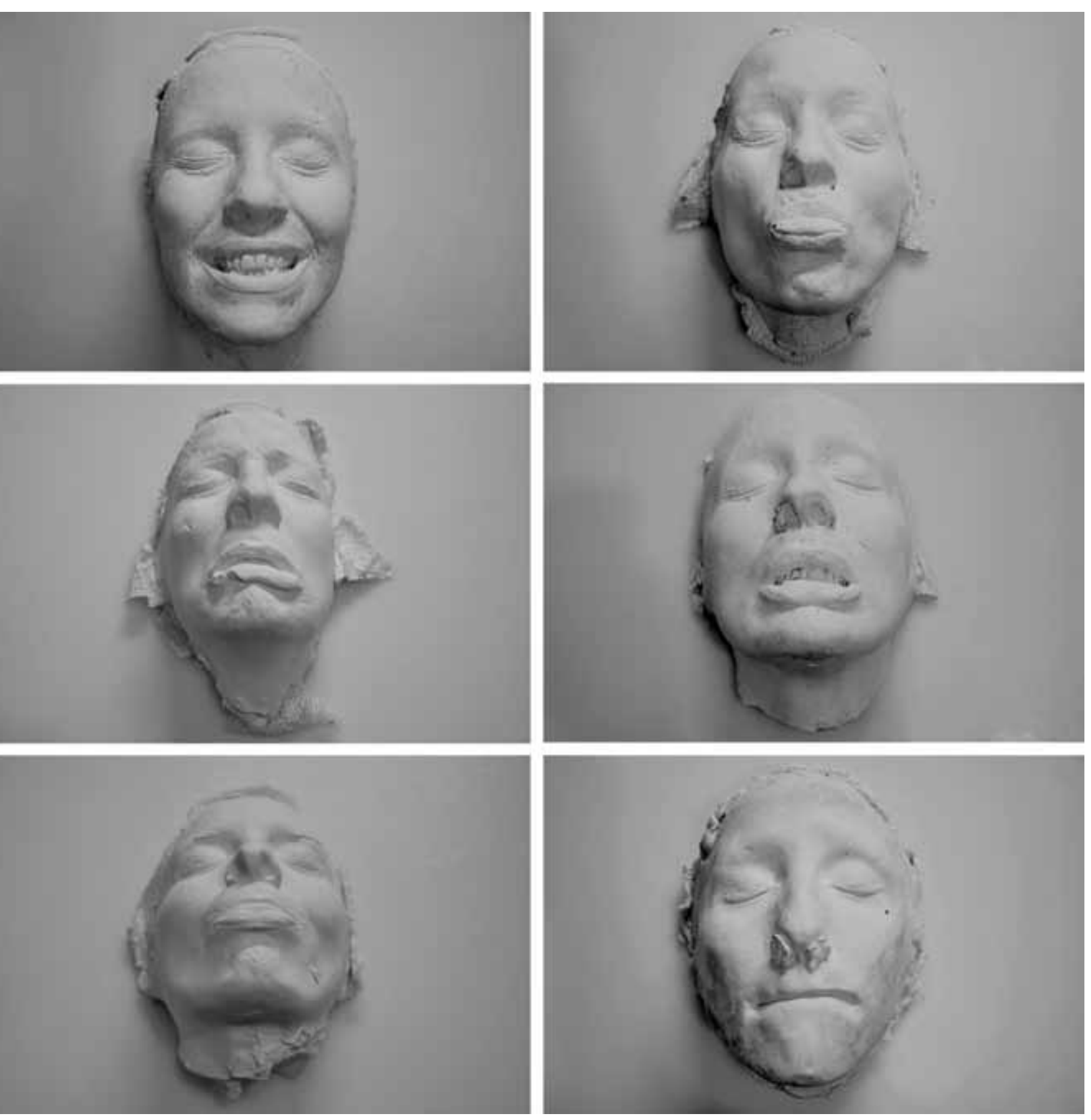


Trata-se de um vídeo realizado em 2018 a partir de fotografias performadas. O trabalho é um desdobramento de "Sim, não, talvez". Sua construçăo formal e semelhante, assim como as técnicas usadas para montagem do vídeo - que é feito a partir de 74 imagens.

Com o corpo centralizado, interagindo com a câmera, coloco uma máccara, retiro os cabelos de dentro da máscera, penteio e me preparo Em seguida faco o mesmo com outras máscars

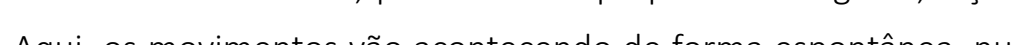
num ritmo linear, sem pausas para câmera fixa, vai registrando a ação enquanto ela acontece, sem uma sequência pré-definida de tipos de postura a serem priorizados.

As imagens fotográficas condizem com os acontecimentos que mostram. Realizo o mesmo processo de produção do vídeo. Observo-as, seleciono-as, distribuo-as e crio uma linha de tempo no computador. A sequência de ações é criada em grupo, máscara por máscara. Esses grupos são organizados numa segunda sequência que não segue a dos acontecimentos. 0 tempo que marca cada imagem não segue um mesmo ritmo. Cada grupo finaliza com uma imagem frontal par a a numa piscada.

Apesar das açōes terem ocorrido de forma linear, o tempo do clique fotográfico não acompanha os movimentos do corpo por completo. Em vídeo, essas interrupş̄es de movimento são completadas pela ilusão de movimento criada na sequência temporal de fotografias ${ }^{17}$.
11" Christine Mello fala que as video-

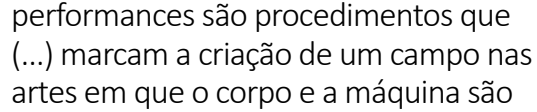
am mesmo tempo contexto e conte

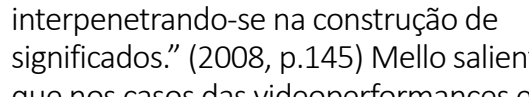

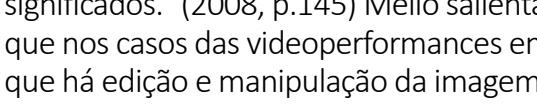

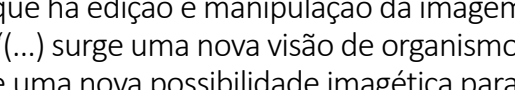
o corpo, que acollhe em sua constituiciẵo
signica toda ordem de interferéncia no

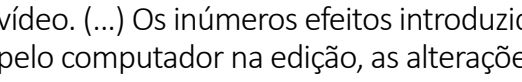

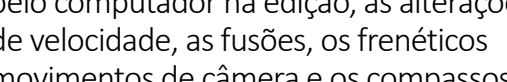

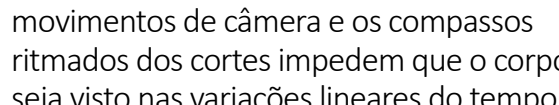

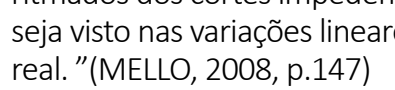




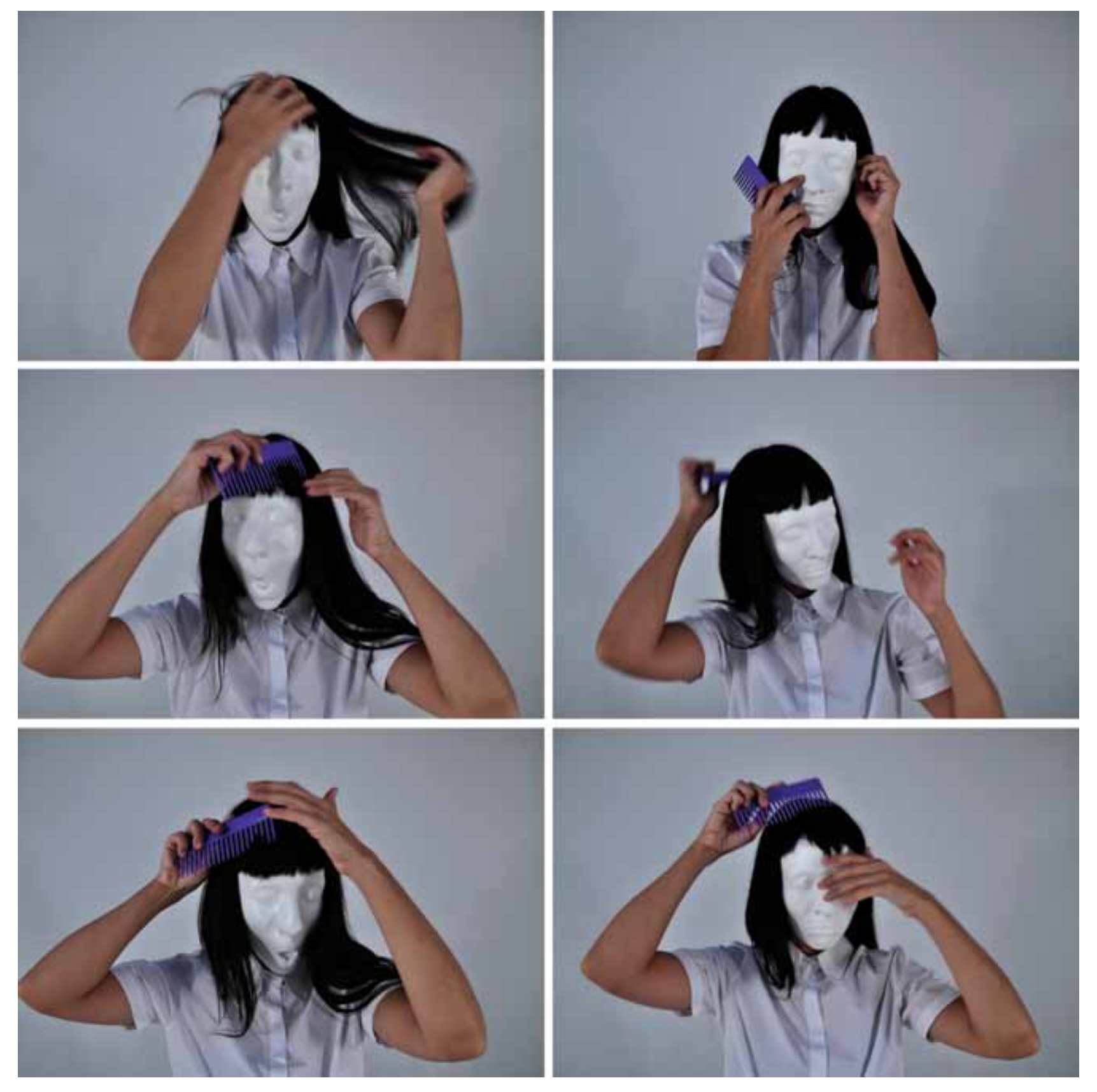

O vídeo faz referência à recorrência do ato de se preparar. Registra preparaçōes, uma após a outra. Açoese e mascaras colocam em xeque determinada construçẫo de subjetividade ligada ao feminino $0^{18}$. Ironia. Paródia.

A relação com a câmera vai sendo marcada em milésimos de segundos, a cada troca de máscara, momento em que me volto diretamente para a câmera e sou fotografada frontalmente jà naturais do corpo e ainda enfatizarem um tipo de movimento meç̂nico artfificial ñ̃o trazem mais uma imobilidade de corpo que fazii relaç̃o com o manequim, como em "SIM, Ñ̃O TALVEZ". coloca em foco o ato anterior ao se apresentar.

O corpo matriz. Molde para reprodução. Meio para formação de imagem

"Lugar onde alguma coisa se gera ou se cria; fonte (...)"19.9.

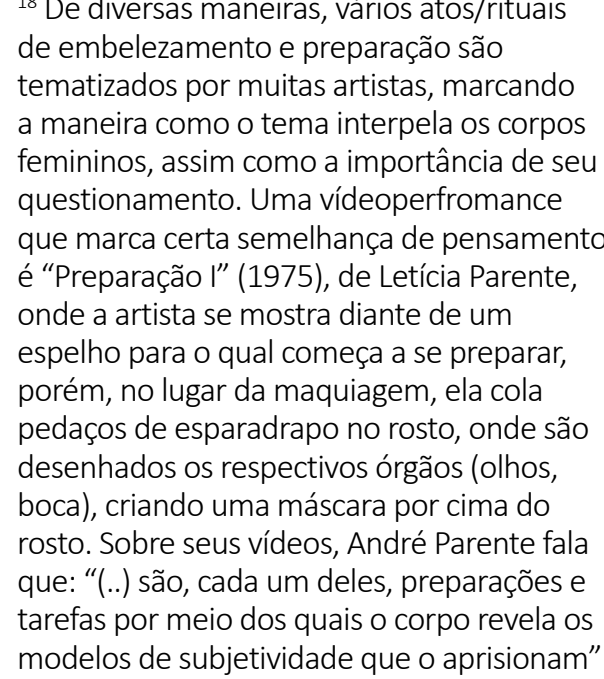

arefas por meio dos quais o corpo revela os modeles de subjetividad
(PARENTE, 2008, p.17)

19um doss significados da palavra matriz
(LAROUSSE, 2001, p.641) 


\section{III. objeto índice}

‥ Entre janeiro e abril de 2019, realizo uma residência artística no programa Pivô Pesquisa Paulo. A residência ocupa um grande vão livre do edifício, que é subdividido em vários nichos separados por paredes de MDF brancas. Uma das laterais do espaço é cortada por janelas de vidro que dão vista para a rua. Todos os nichos são abertos para que as atividades sejam partilihadas pelos residentes e pelo publico. O espaço tem grandes colunas que o atravessam, paredes brancas, sistema de liuminaçáo independente por cal ha, cháo de concreto sem acabamento. As colunas e as linhas sinuosaas que desenhiam os Iimites do espaço são marcas da arquitetura, cuja conceppşão leva assinatura do arquiteto Oscar Niemeyer.

A proposta para a residência dá prosseguimento aos trabalhos com moldagem do rosto, resultando agora em trabalhos tridimensionais que vão explorar as possibilidades desse espaço. A autorrepresentaçăo, hoje multiplicada pelo universo do "selfie", continua sendo pensada no contexto atual onde $o$ ato de se fotografar é parte dos hábitos comuns, alimentada pelas redes sociais e pelos celulares com suas multiplas funçôes. Contexto onde corpos anônimos se representam diariamente em atividades corriqueiras, cujo modelo de representação parece ter um paralelo com o modo de representar a vida de celebridades feita pelas mídias de massa há tempos (colocando em foco atividades aparentemente banais de suas particularidades). Hoje, essas não são mais prerrogativas da vida célebre, nem estão no controle apenas das grandes mídias. Os códigos e modelos de comportamento social. A reprodução. A produção dos corpos. A produção das identidades. 


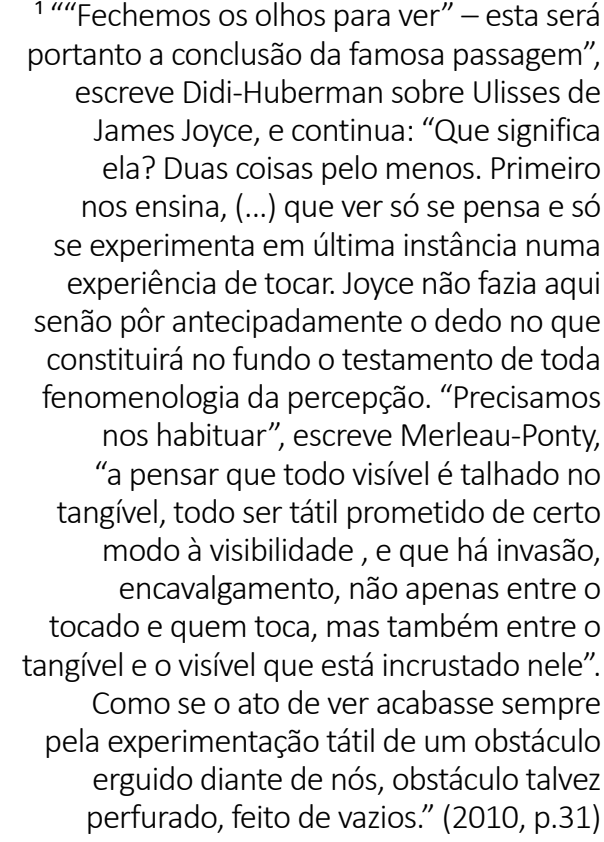

o trabalho mantém propositalmente essa primeira analogia entre objeto
representaçăo, partindo de uma reflexāo

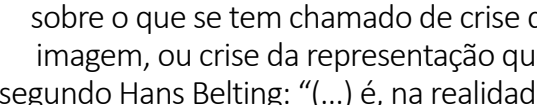

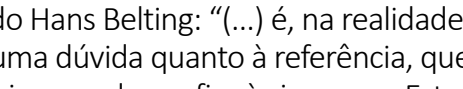
deixamos de confiar às imagens. Estas
acassam quandon nao encontramos nelas
nenhuma analogia com aquilo que as

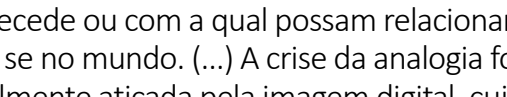

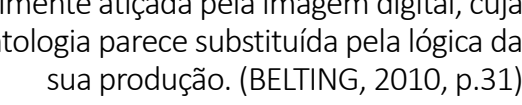

o interesse em abordar códigos gerais que informam os corpos hoje, que estão por trás de comportamentos, e não em tratar suas caracteristicas específicas. Sigo com a reprodução dos moldes do rosto criando caber

Reproduzo em série alguns gestos e expressões pensando em seu esvaziamento pela reetição. Escolho inicialmente o gesto de sorrir gesto recorrente na prerrogativa do ato de se fotografar atualmente. Uso um molde de 2017, cuja expressãot traz uma tentativa de sorrir. Durante

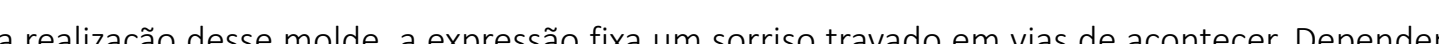

A cabeça feita a partir do molde do corpo apresenta verossimilhança com o corpo. Diferentemente da fotografia analógica, aqui, os traços da semelhança são marcados no tridimensional da matéria, propõem uma experiência tátili'. O objeto-cabeça traz detalhes do corpo em relevos, trabalha numa escala humana, mantém uma dimensão de identificação entre o corpo moldado e o corpo de quem vê.

O objeto como índice de corpo². Presença e ausência.
I. O gesso éa matéria-prima escolhida para reprodução nesse momento. Sua cor branca rebate moldagem e reprodução fiel de um mesmo objeto em grande escala, sendo material que remete à arquitetura por seu uso na construção civil, eà reprodução em série, sendo, desde a Antiguidade, muito usado nas artes visuais principalmente como material de processo e de reprodução, e a partir da arte moderna como material definitivo de algumas obras.

As peças são produzidas em série e manualmente. 0 corpo continua se afirmando na produção do objeto, e se maifesta também nos pequenos defitos resultantes de procedimento Mum sum geral, apenas algumas in

As cabeças são maciças e trazem todos os detalhes do rosto. Mostram a parte frontal, sem a nuca, nem as orelhas. A nuca é lisa e reta. Os olhos estão fechados. As cabeças mantêm a cor branca do gesso e não levam acabamento. Produção manual que remete à produção em série. Repetiçăo. Esvaziamento. Padronizaçāa. Apagamento.

O rosto é tomado como signo de época. Apesar da semelhança, a cabeça resultante não deixa claro se o rosto é feminino ou masculino. Corpo anônimo. $O$ procedimento vai chamar para a existência do corpo marcando seus detalhes no objeto. A apropriação do corpo.

Orosto expressa um código de época através do gesto de sorrir. Fala de um código que informa os corpos de hoje. 0 gesto de sorrir expressa um código do ato fotográicico, e não uma emoção. A multiplicação do mesmo rosto pretende gerar um efeito de planificação e, em decorrência, o apagamento dessa identidade. O objeto e sua multiplicação trazem dados ambíguos, falam ao mesmo tempo de analogia (entre corpo o objetto-cabeça) e simulação (de gesto que não representa
"A questāo do retrato começa talvez no dia a não estar mais ai porque a terra comę̧

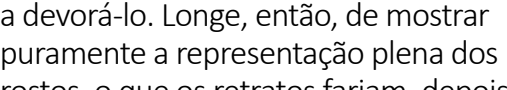

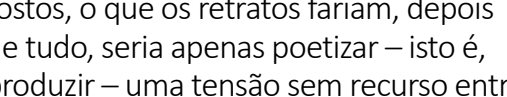

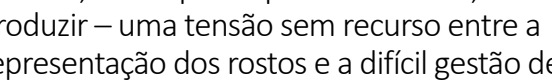

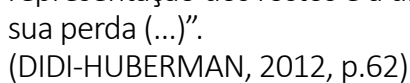


de ideias projetadas anteriormente, outras surgem na relação com o espaço, outras ainda vão

sendo reestruturadas num processo de montagem e desmontagem dos trabalhos no espaço. Nessa

fase de experimentacão, em cada proposição o objeto-cabeça se comporta de formas diferentes

criando imagens que por vezes retomam características já marcadas em outros trabalhos, e por outras trafegam por novos pensamentos.
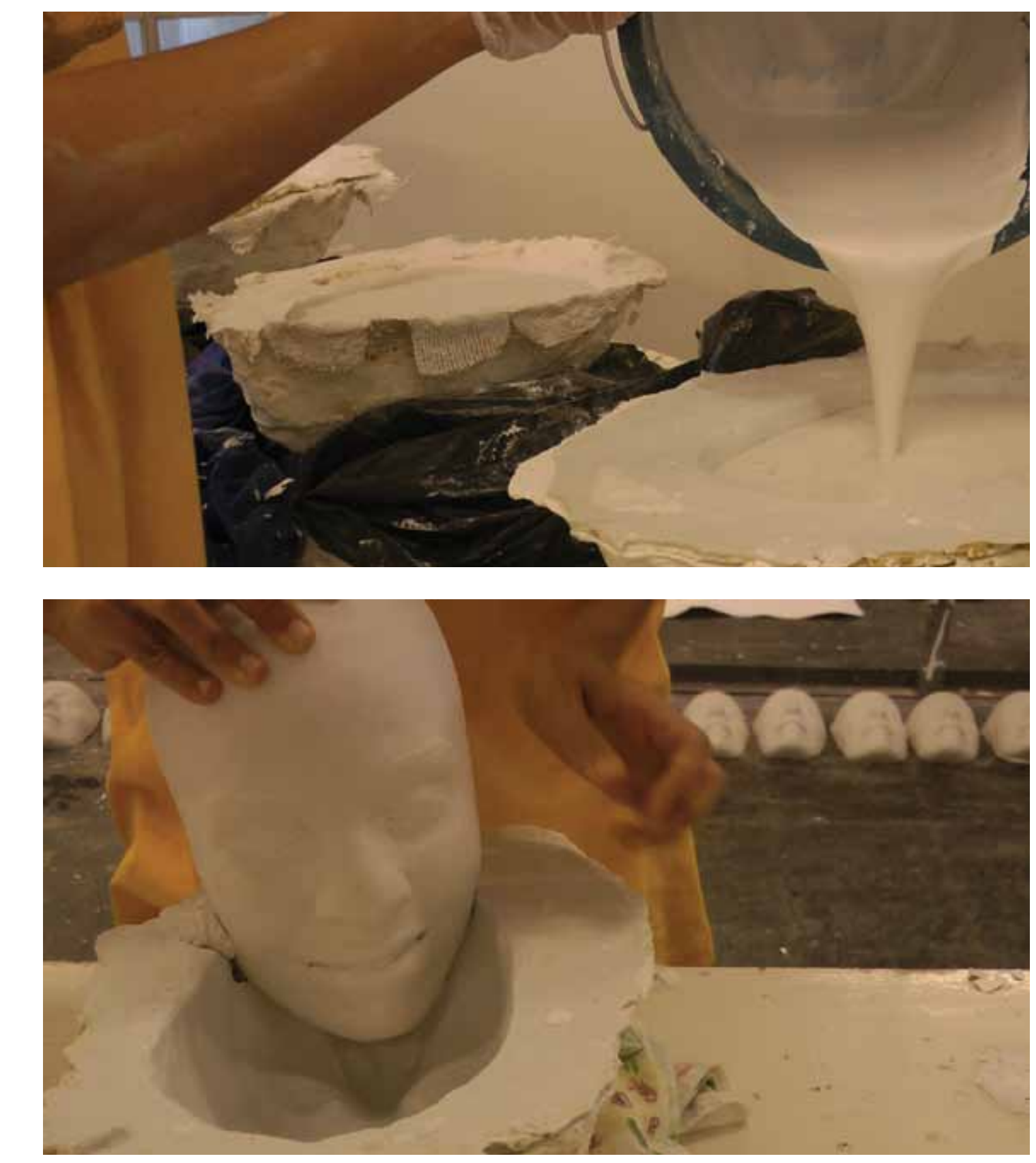


\section{“CHÃo” (OBJeto-CABEçA, GRADE, ESPAÇO)}

Um gesto facial realizado em 2017 é gravado na matéria. As cabeças resultantes desse gesto so usadas para diferentes proposiçōes durante a residência em 2019. Cada situacăo busca colocar o objeto-cabeça em relação às arquiteturas dos espaços disponivivis. As proposiçōes testam os sentidos que vão se somando a cada tipo de relação entre objeto-cabeça e espaço.

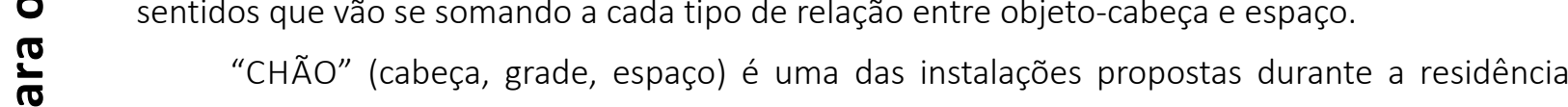

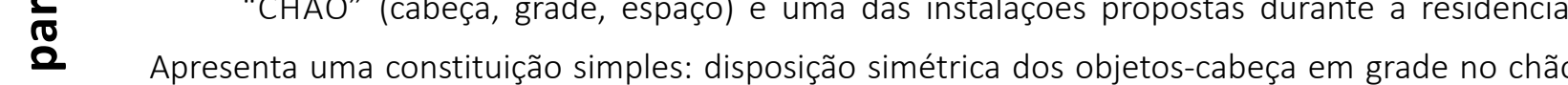
ע

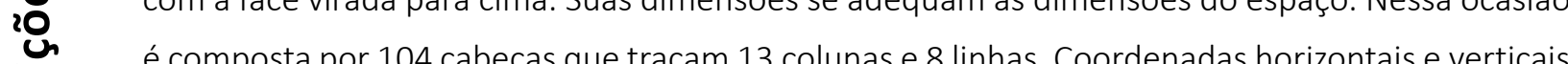
Montagem em grade. A divisão do espaço chama para a maneira projetiva de divisão de território feita pelo pensamento arquitetônico. Aqui, ela começa com o espelhamento de 3 paredes do espaço para dentro, criando linhas que se distanciam em 1 metro de cada parede, permitindo uma área de circulação em torno. 0 espelhamento cria um desenho retangular nas dimensões de 3,5 metros de largura por 3 metros de profundidade. A partir dessas medidas externas, o espaço é dividido considerando as dimensões das cabeças. Um desenho gradeado é feito no chão do espaç̧ para posicioná-las. Depois de posicionadas, é retirado, restando como virtualidade
3 A montagem em grade é parte da obra,

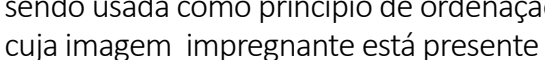
diversas dimensínes do cototidiano, deste as

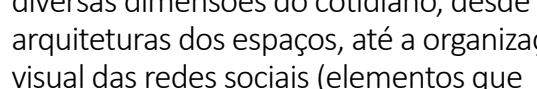

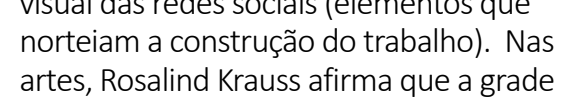

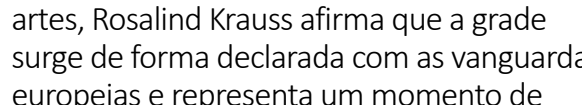
europeias erepresenta um momento de chamada para a planaridade de seu meio da arte como sende ac acelarara o espages,

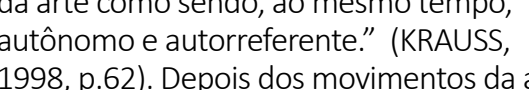

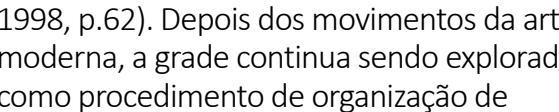

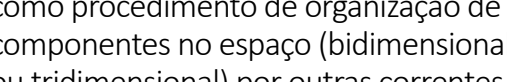

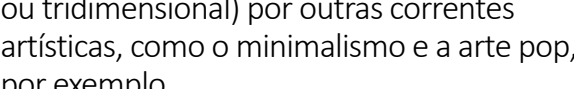

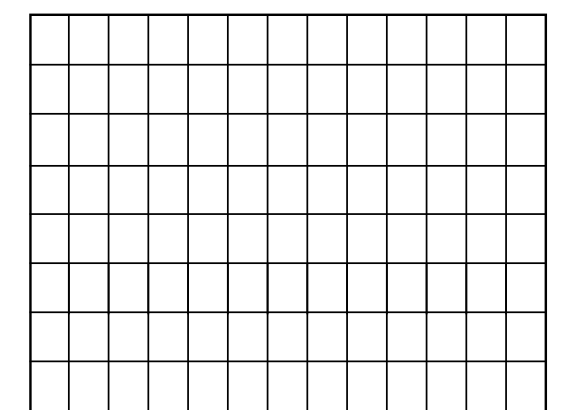




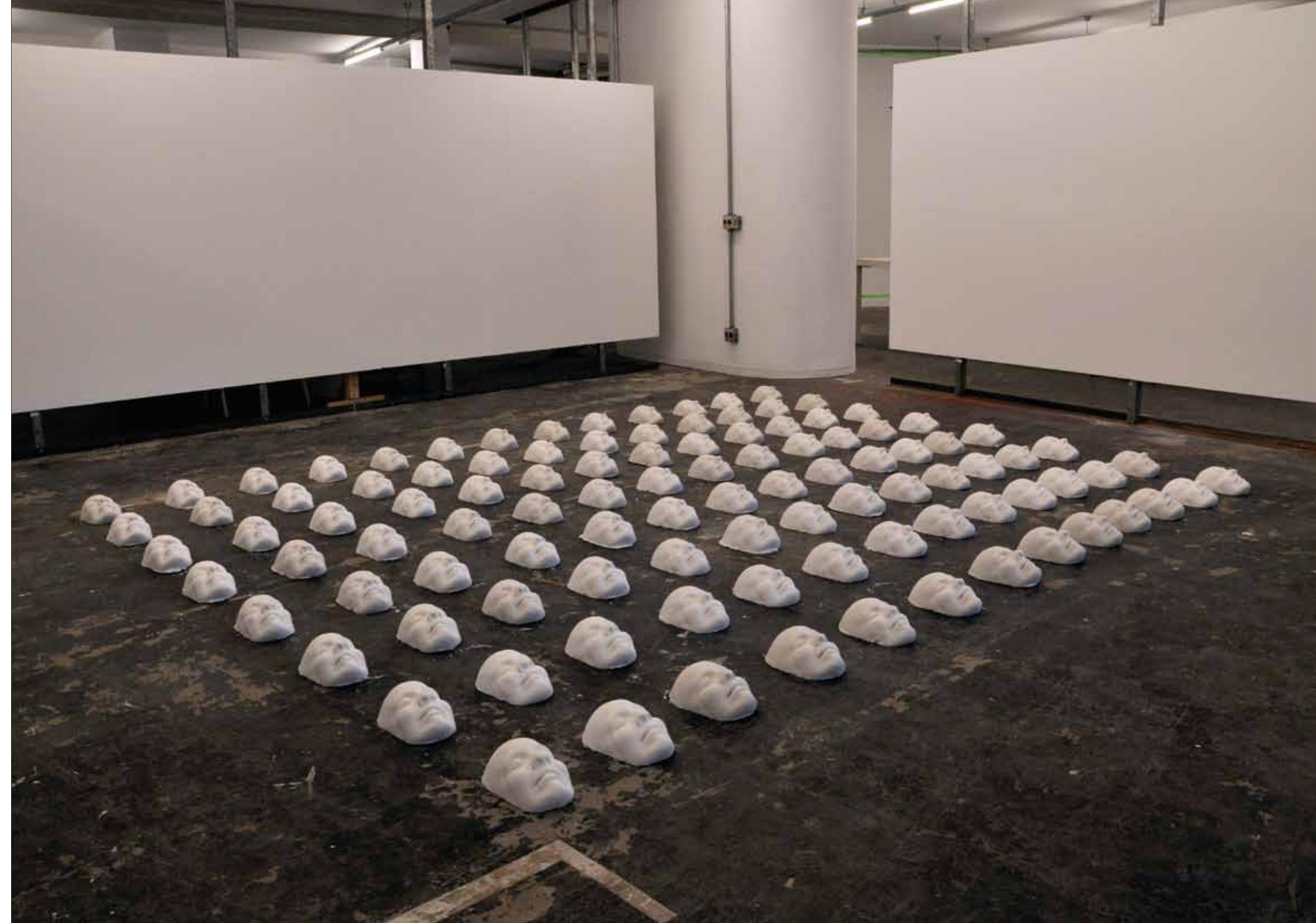




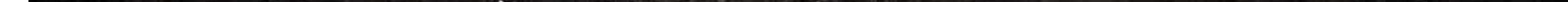




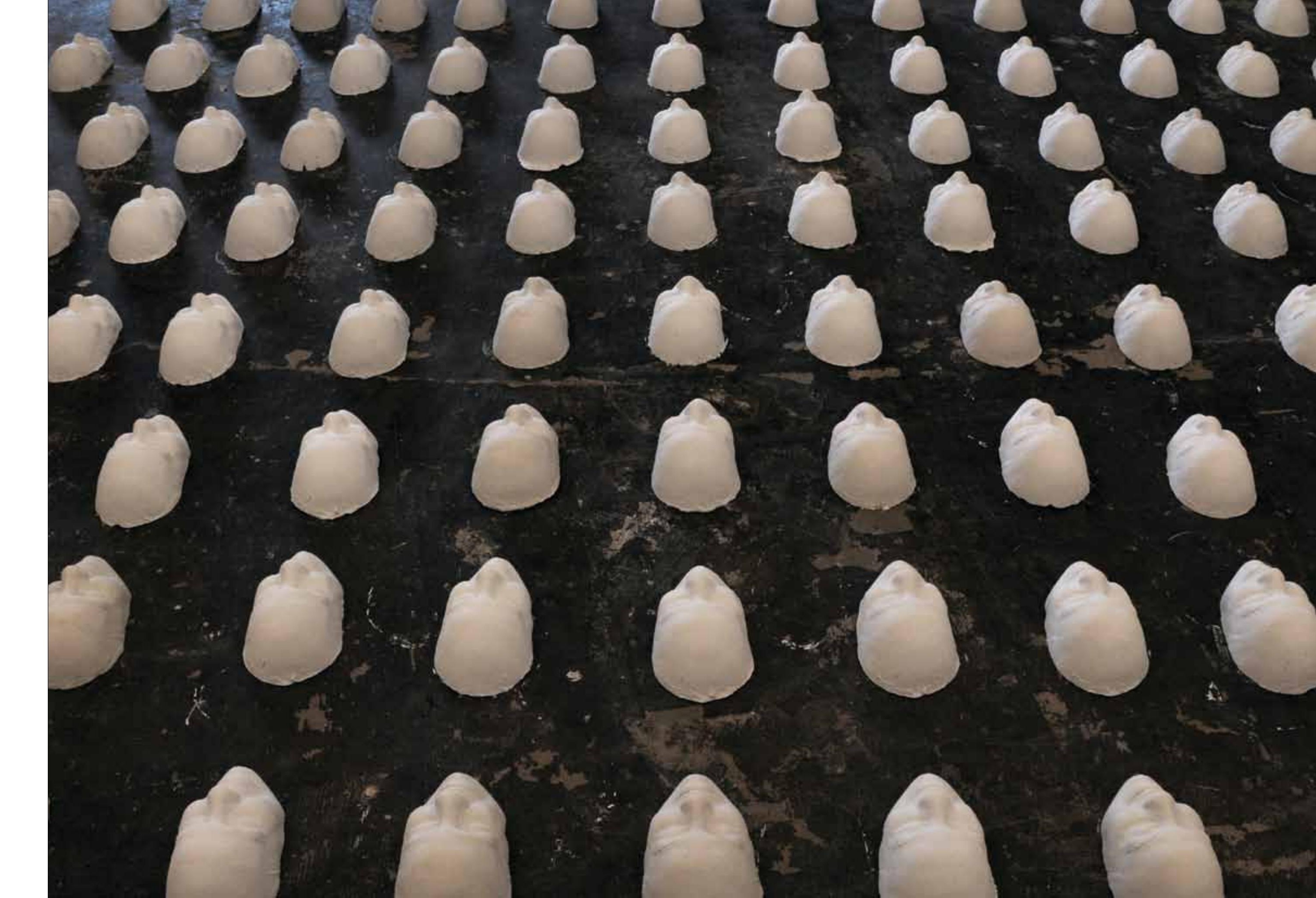




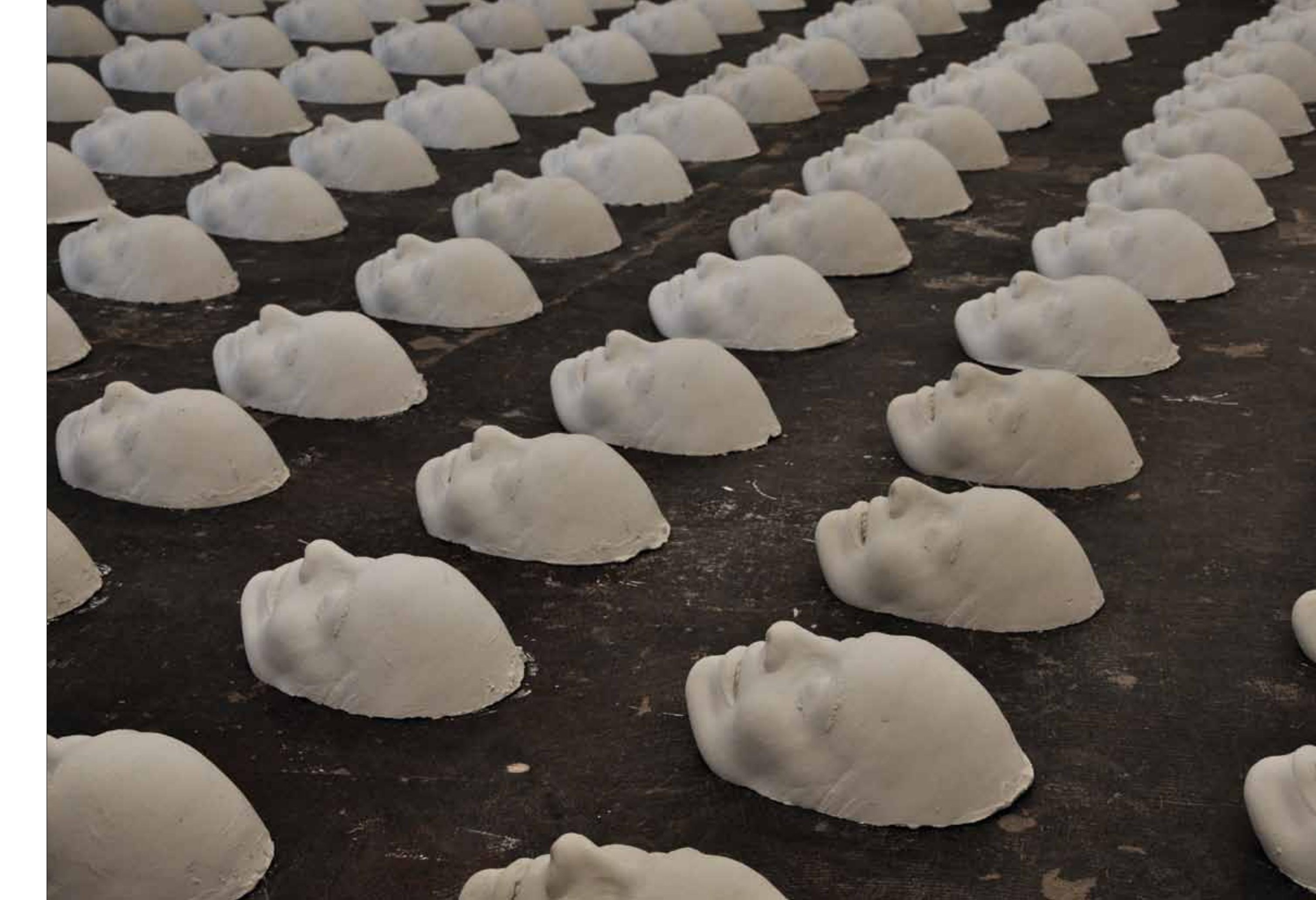





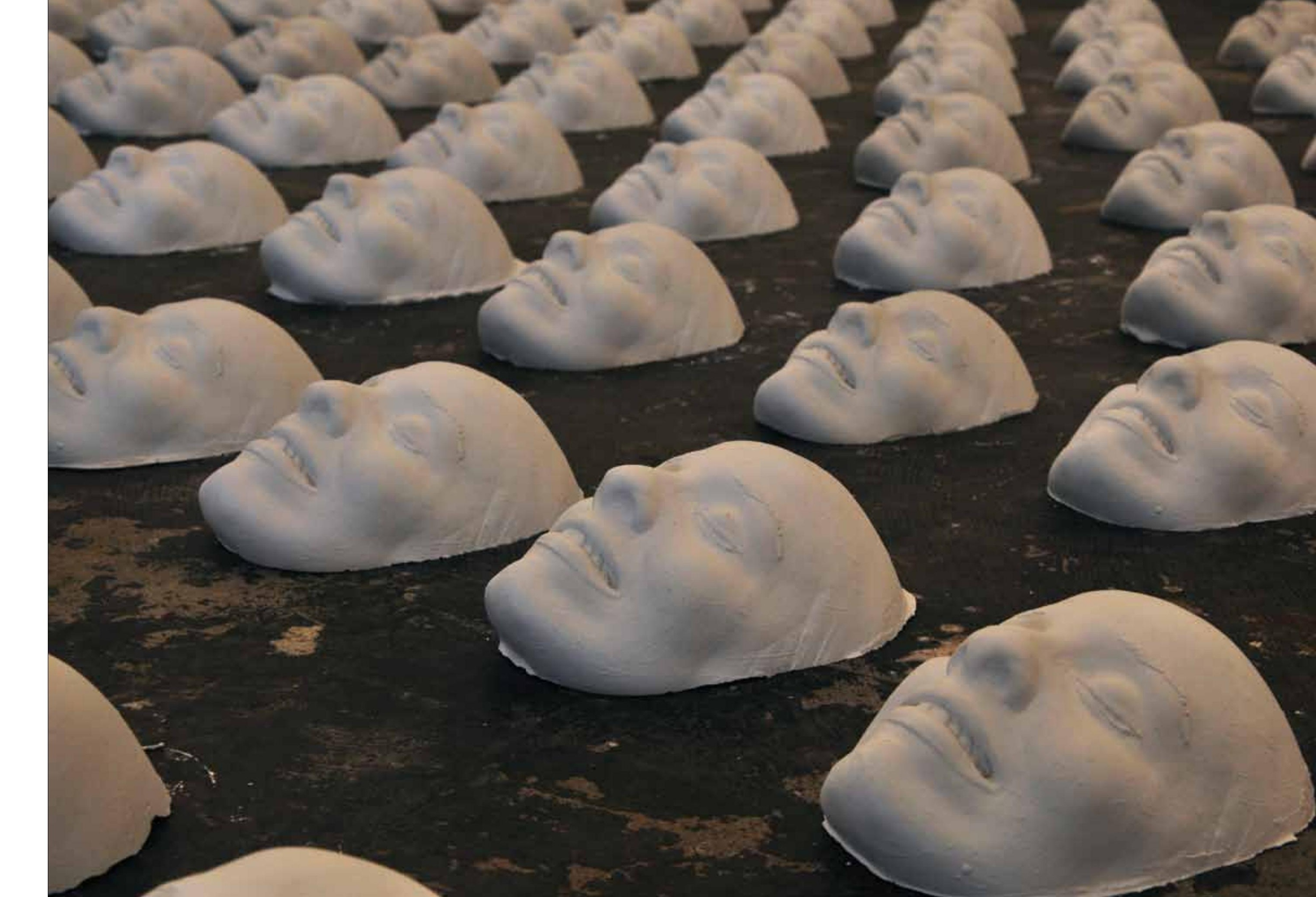


O nicho do local não é completo por cabeças. Um bloco retangular se centraliza nele. Pode ma maneira de pensar que organizze divide espaço e objetos. Ordenaç̧ão. Simetria. Pensamento arquitetônico. Cálculo matemático. Procedimento simples de divisão e distribuição. A montagem em grade é um elemento de conexão e construção de sentido. Ativa determinadas percepp̧̄oes sobre o objeto. Nivelamento. Uniformização.

$$
\text { A cor branca do gesso reflete a cor da parede e se destaca da cor escura do chão. Apesar de }
$$

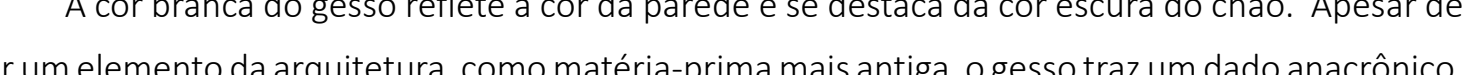
ser um elemento da arquiteura, colicãão das pecas no espaço, por outro lado, chad a anacronnico, que transitam entre robô e cil que hisula

Rosto anônimo multiplicado no espaço. Expressão de sorrir em posto irônico. Escala do corpo mantida em cada objeto e na maneira como ocupam o espaço. Um objeto-cabeça por espaç̧o. A padronização na forma. Os erros de produção visíveis na visualização do trabalho. 0 corpo que se manifesta por trás do objeto, a partir do processo de produção manual. As diferenças mantidas no erro de produção. Desvio.

Rosto moldado. Corpo fragmentado. Metonímia. Parte pelo todo. 0 corpo presente como virtualidade

\section{“SEM TiTULO” (OBJETO-CABEÇA, BARRA, PAREDE)}

Outra proposta de instalaçãa feita para um dos espaçcos disponiveis na residência que possui uma parede central ladeada por 2 nichos estreitos de aproximadamente 70 centimetros de largura e 150 centimetros de profundidade, ealtura do teto contigua.

A instalação é constituída por 4 cabeças furadas ao centro da testa e 2 barras rosqueadas de ferro. As barras são fixadas entre as paredes do nicho numa altura de 1,65 metros (altura do olhar

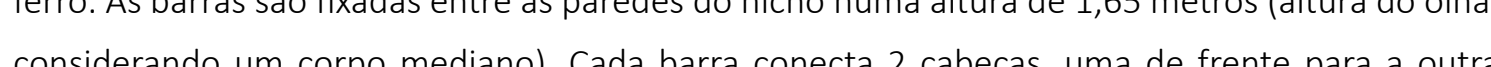

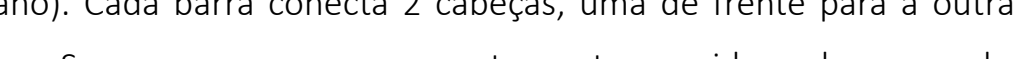
cabȩ̣as. Os 2 nichos são compostos da mesma forma. Espelhamento. 


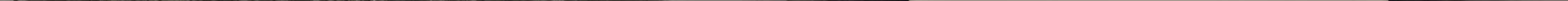




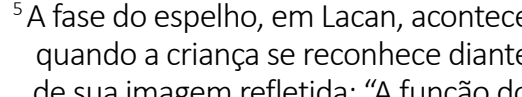

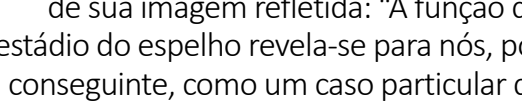

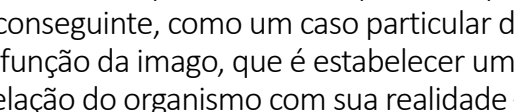

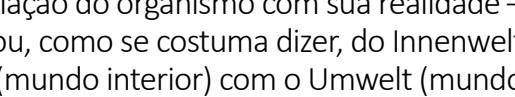
circundante). (.). Esse desenvolvimento
vivido como uma dialeteicic temporal, que

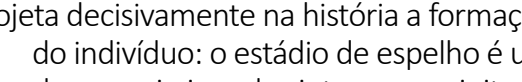
id nuficiềncia para a antecipaçaço-e eque dentificaçăo espaciala, as fantantasias

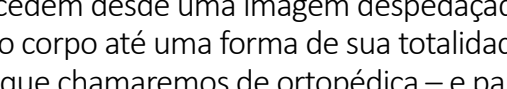

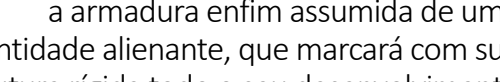
struturar ríida todo o seu desenvolvimento

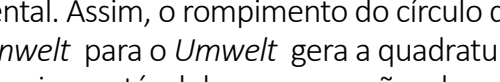

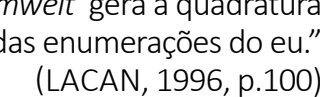

6"Interpretou-se com frequência
verso consumistac como um agente
de

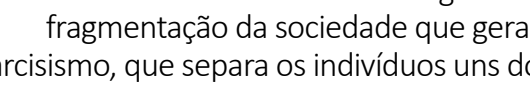

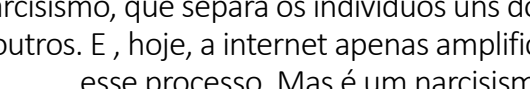

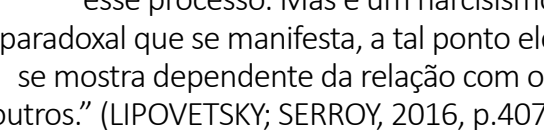

objeto e espaço. 0 espaço constituinte da obra. O objeto-cabeçą suspenso. A conexão arquitetura. A barra conecta objettos-cabeça entre si, assim como faz sua conexão com o espaço. O objeto-cabeça é apenas encaixado na barra, está solto. As feiçōes voltadas uma para a outra Espelhamento. 0 espelhamento interno, entre as duas cabeças. 0 espelhamento externo, da repetição do conjunto no espą̧̧o- possibilidade gerada pelo local 5 .

Dois rostos iguais voltados para si. A temática do narcisismo parece inerente às autorrepresentacões, estando como pano de fundo em toda essa produção que trabatha o tera

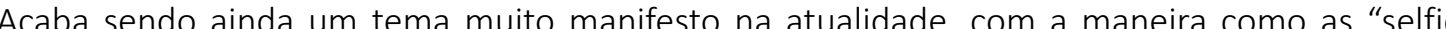
da autorrepresentaçăo e vou multiplicando minha imagem. A repetição é trabalhada como un aspecto de mecanismos atuais que estimulam comportamentos constantes de auto-observação autorregistro e auto-exibição (padrão de comportamento dentro das redes sociais). A articulaçąa dos objetos-cabeça replicados no espaço reforça o narcisismo implícito no ato de se representar, porém, cada proposta traz ideias opostas à de exaltação da figura replicada. Ambiguidade.
“SEM Título" (OBJETO-CABEÇA, BARRA ROSQUEAdA, PAREDE ENTRE OBJetos)

Proposta de instalação que se realiza no mesmo ambiente que a anterior. Em outra parede do espaç̧, a instalação é composta por 2 objetos-cabeça furados na altura da testa e 1 barra rosqueada no tamanho de 1 metro (tamanho original comprado em fábrica). A barra atravessa uma parede e os 2 objetos-cabeça são posicionados em lados opostos, um de frente para o outro, com a parede entre eles.

Junto com a proposta anterior o espaço recebe as duas instalações compostas de elementos semelhantes. As relacōes invertidas entre seus elementos provocam senfidos difertes As como forma de experimentação da relação com o espaç̧, porém, a ideia segue em trabalhar com outros acabamentos para os objetos dessa proposta. 

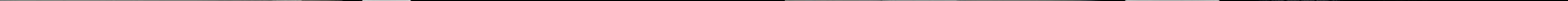
Na passagem de entrada da exposição, de 120 centímetros de largura, duas cabeças de resina transparente estão posicionadas, uma de frente para a outra, numa attura de 2 metros aproximadamente.

"O DUPLO" (2019) é uma instalação de parede realizada numa exposição coletiva meses depois da residência, que parte de uma conformacôo semelhante às 2 propostas anteriores.

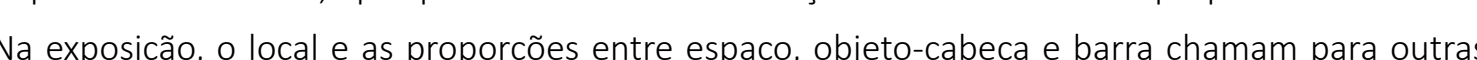
Warra. A barra é incorporada ao objeto-cabeça o o con objeto-cabeça é fixado na parede por meio da barra distanciando-se em 15 centímetros dela, um de frente para o outro. A transparência da resina deixa entrever a parte interna do objeto, criando uma relação entre interno e externo, deixando a barra fixa visivel internamente e incorporando a iluminação do ambiente ao objeto. Passagens.

"Há mais: od deleitet tambémé éo do duplo, Reveladora a e esse respeito é a forca a

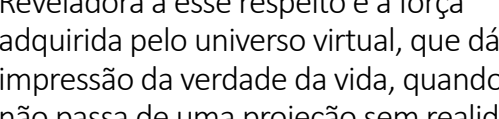
concreta. (...) Uma projeção imagináría que
ăo e sentida como uma vida menor, uma

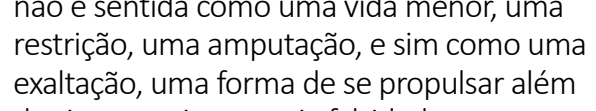

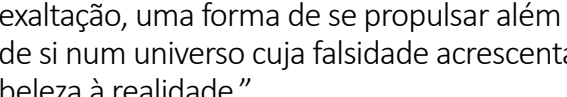

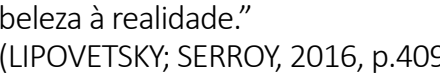



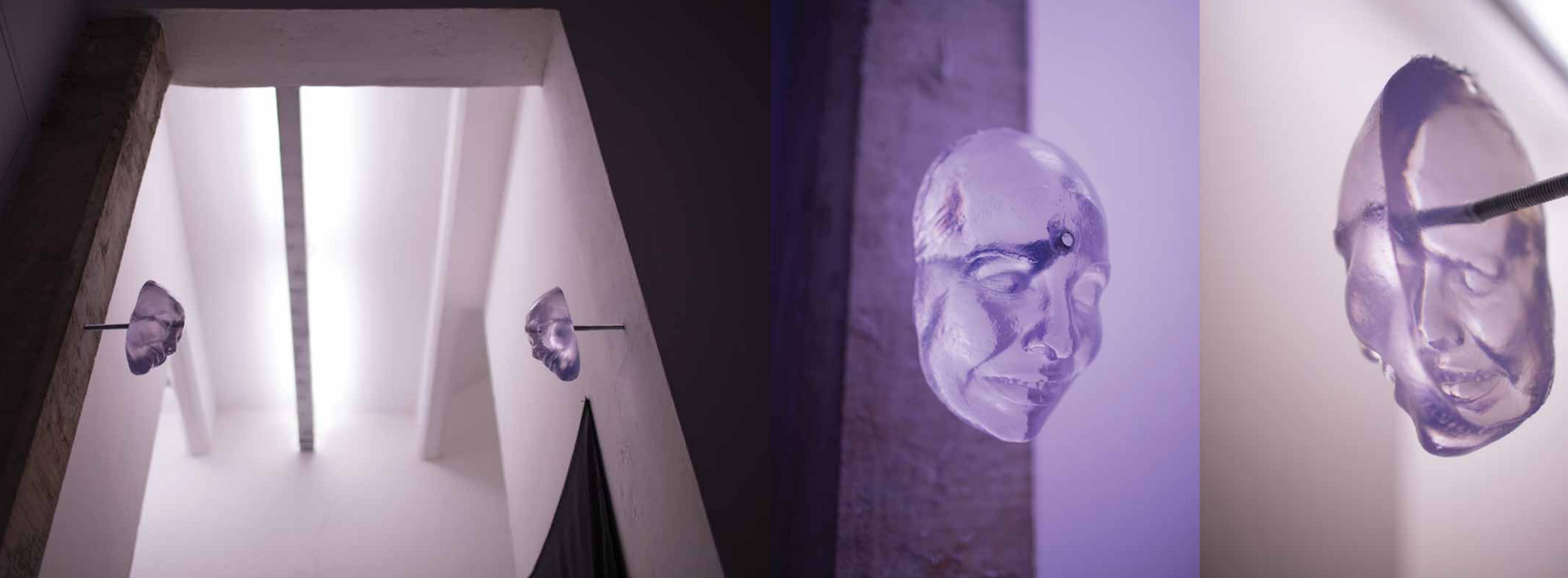
Trata-se de uma instalação composta por uma coluna de ferro (de medidas convencionais de fábrica), 28 objetos-cabeça furados ao centro da testa, 14 barras rosqueadas de 60 centímetros cada. A coluna de ferro está fixa no espaço do chão até o teto, com 3,5 metros de altura aproximadamente. Através de suas grades, 2 barras são apoiadas intercaladamente em 7 dos 14 andares de arame do colu As barras atravessam a coluna uma por cima da oura far 7 dos 14 e apoiam 1 obje to- dacera em cada uma das 4 extremidades.

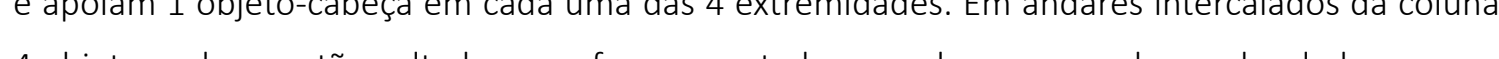
4 objetos cabeça estav volos pra fora 4 costados nacolna, 4 barras atravessando e saindo pela frente do objeto.

A instalação remete a um dos elementos marcantes da arquitetura desse espaço, a coluna, fazenda uso deseve

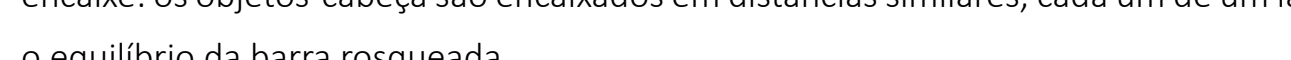
o equilibrio da barra rosqueada. 


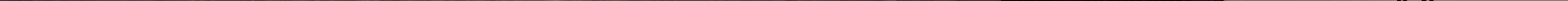

月

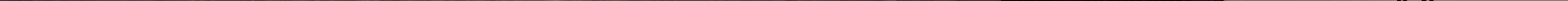

$=8$
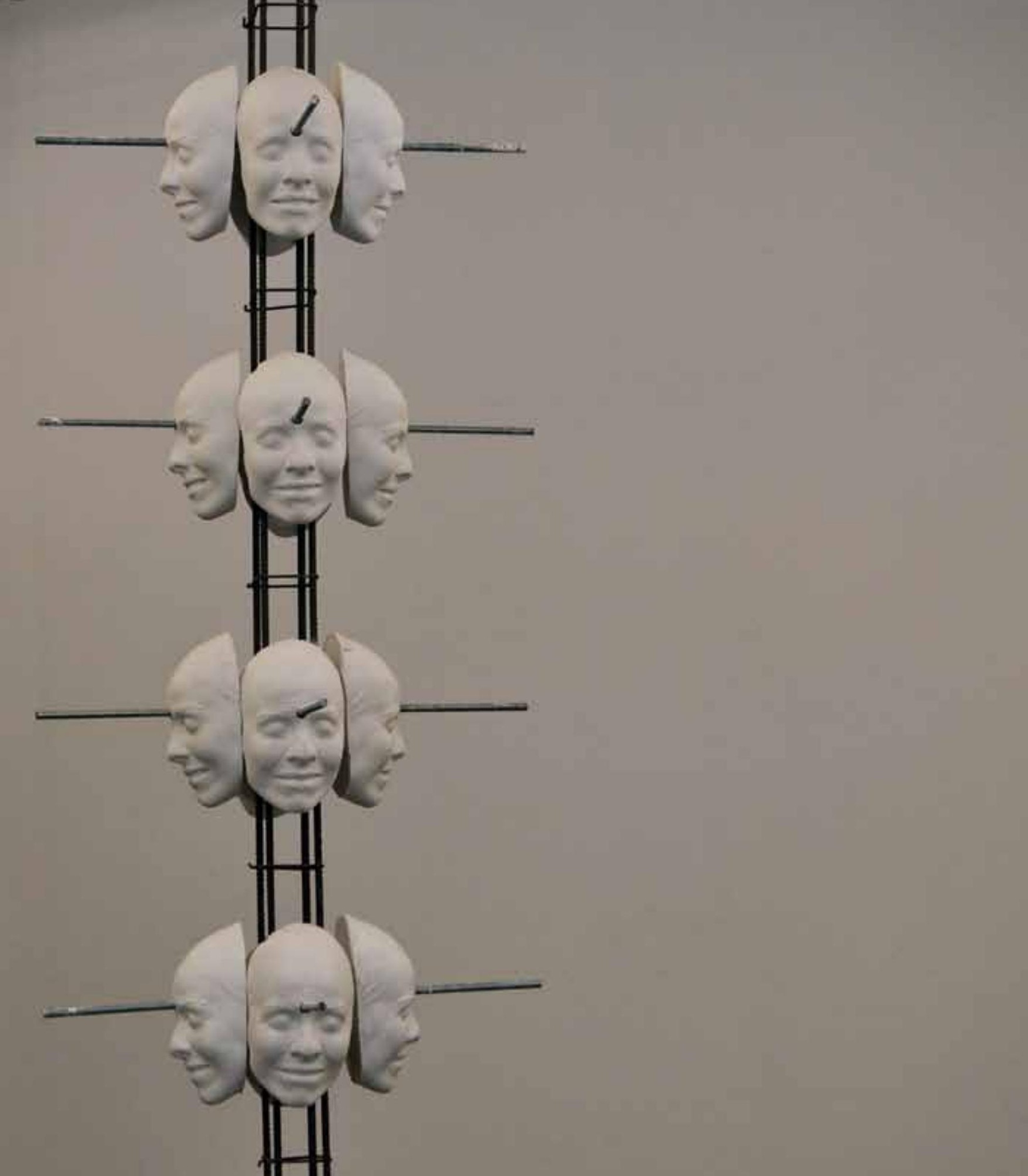
Ogesso. A barrra.A coluna. Elementos dotrabalho retomam elementos daarquitetura. Acoluna A coluna. A verticalidade. A sustentação. A estrutura. $O$ interno. $O$ vazado. Relaçăo entre interno e externo. $O$ objeto-cabeça furado. $O$ encaixe pela barra. $O$ atravessamento. A montagem. $O$ equilibrio. A repetição do mesmo objeto circularmente em cada andar. A horizontalidade. Os objetos-cabesa com suas expressões viradas para fora. A mesma face vista em todos os lados. Todos os lados do mesno objeto sendo vistos a mesmo tempo. Giro em 3600 . O totem 0 objeto de culto. 0 objeto de controle.

Otitullo do trabaho "Totem" far mencão as monumentos escultóricos de culto, que tarim figuras escupidas uma figuras esclipdasu a da outra. Essas figuras representavam o símbolo ancestral de uma tribo ou coletividade. Aqui, essa configuraçăo é retomada pela coluna que faz remissão à forma de uma época.
"LINHA" (CABEÇA, BARRA, EMPILHAMENTO, FILERA)

Trata-se de uma última proposta de ocupação do espaço da residência. A instalação é composta por barra rosqueada, objetos-cabeças furados na região da testa, organização no espaço e divisão do espaç̧o. 9 objetos-cabeça são encaixados em cada barra. As cabeças jjudam a manter cada barra em pé, sem ajuda de outros artifícios. As barras são posicionadas em fileira no espaço, com espaçamento semelhante entre cada uma. A ideia é que a fileira de barras se posicione em locais de passagem, ou centralizadas no espace, de modo aue se tenha que passar por ela para

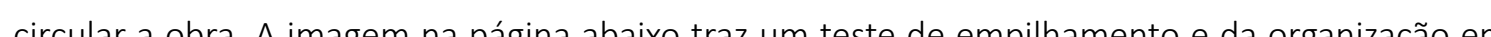
fileira, mas não trás o posicionamento no espaço.

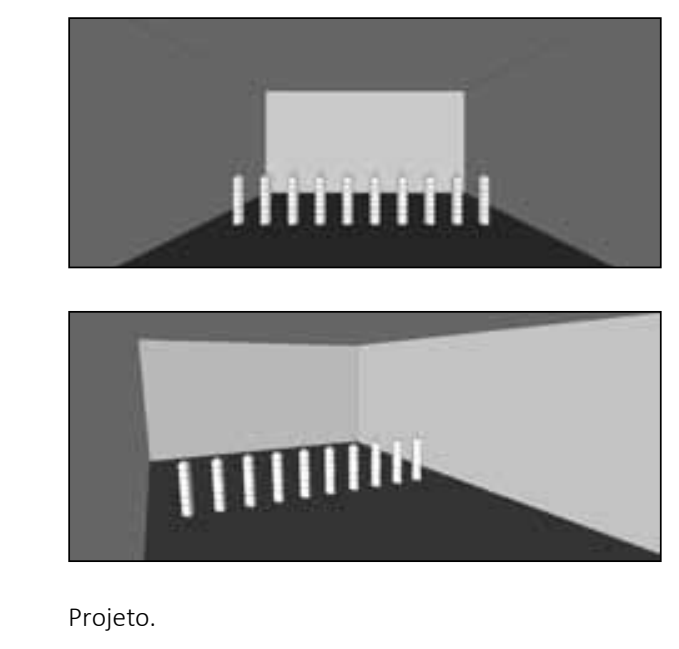




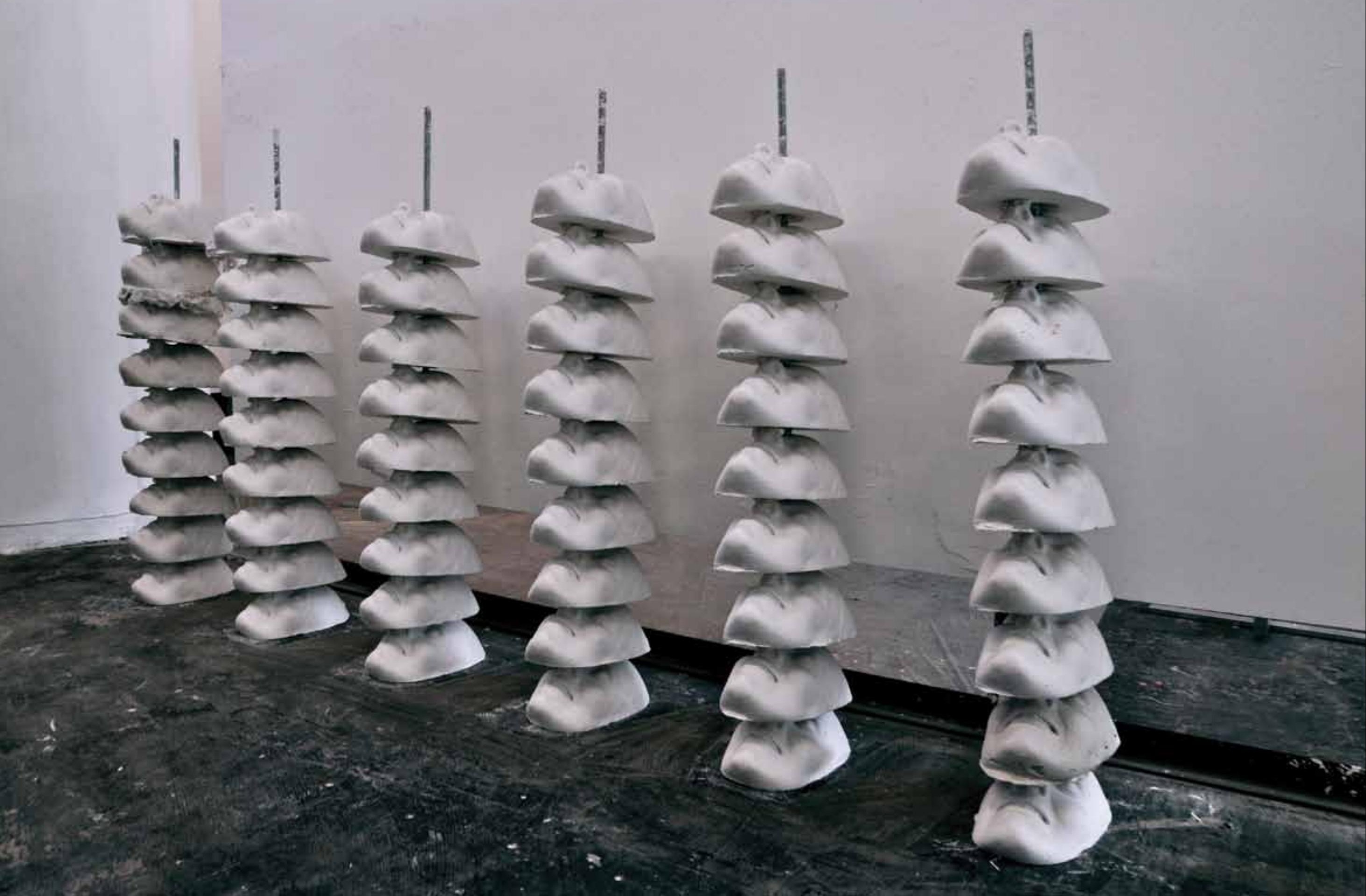
Controle.

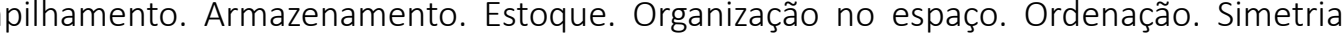

A questão da produção em série está implíita em todos os trabalhos dessa série em que um mesmo objeto-cabeça se repete. Nessa proposta especificamente, a montagem do trabalho retoma um tipo de organizaç̃ão fabril, de empilhamento de objeto, que deixa a questão em maior evidência. Ao mesmo tempo em que essa imagem leva para a ideia da produçāo fabril, também traz uma violência de seu atravessamento.

Em cada modo de ocrpaço do espaço a residência com o elemento cabeca procuro testar (a)

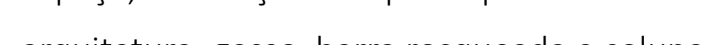

Nesses trabahthos, a presença do corpo vai desaparecendo (não está mais na performance, nem na fotografia) e se mantem como indice no objeto que étomado do corpo, e comovifualidade a partir do proprio processo que étrdo manual e deka suas marcas nos objetos. 
Volto-me para outra série de emojis de gestos manuais e os reproduzo novamente com o corpo, pretendendo construir outro catálogo de gestos, partindo também de códigos atuais da comunicação escrita virtual. Se na conversa ao vivo, o corpo transmite e completa o sentido da fala, na linguagem escrita, o emoji reintroduz o corpo na comunicação a partir da reprodução de sua imagem, e diminui a separação entre imagem e texto. A conversa por mensagem de texto parte da premissa de um corpo dilúído e multiplicado em sua presenņa virtual.

Crio diversos moldes de gestos para realização de instalaçāes diferentes, que partem da Crio diversos moldes de gestos para realizaçáa da instabsos diferentes, relação entre objeto replicado, espaço e uma forma pré-estabelecida para instalação do objeto no espaço. Para uma primeira instalaçăo, escolho o gesto de positivo, por sua recorrência na comunicaąão e por ter sido um gesto que claramente foi ressignificado depois das redes sociais. O gesto de positivo que informou a criação do ícone (em que o dedo polegar está apontado para cima, enquanto os outros estão recolhidos), depois de seu uso corrente nas redes sociais, volta agora para o corpo como sinal de curtir, podendo depois ser reincorporado a uma outra criação de ícone. Sobreposição de sentidos. Circularidade e imbricação entre corpo e código.

Molde. Com um pote proporcional ao tamanho de minha mão, e uma pasta de alginato, estabilizo um gesto com a mão direita e a insiro dentro da massa até a altura do punho. 0 gesto se mantem até o material endurecer. Em poucos minutos a massa fica branca, firme, mas flexivel. Retiro a mão. Jogo uma pasta de gesso bem liquida dentro do molde. Depois de endurecido, retiro o modelo da mão em gesso e produzo um molde de silicone para réplica. As mãos aparecem em detalhes. Cada uma é replicada com uma barra rosqueada dentro para ser fixada na parede. Molde do corpo realizado. Modelo para réplica. Corpo em fragmento. 0 objeto ainda como indice do

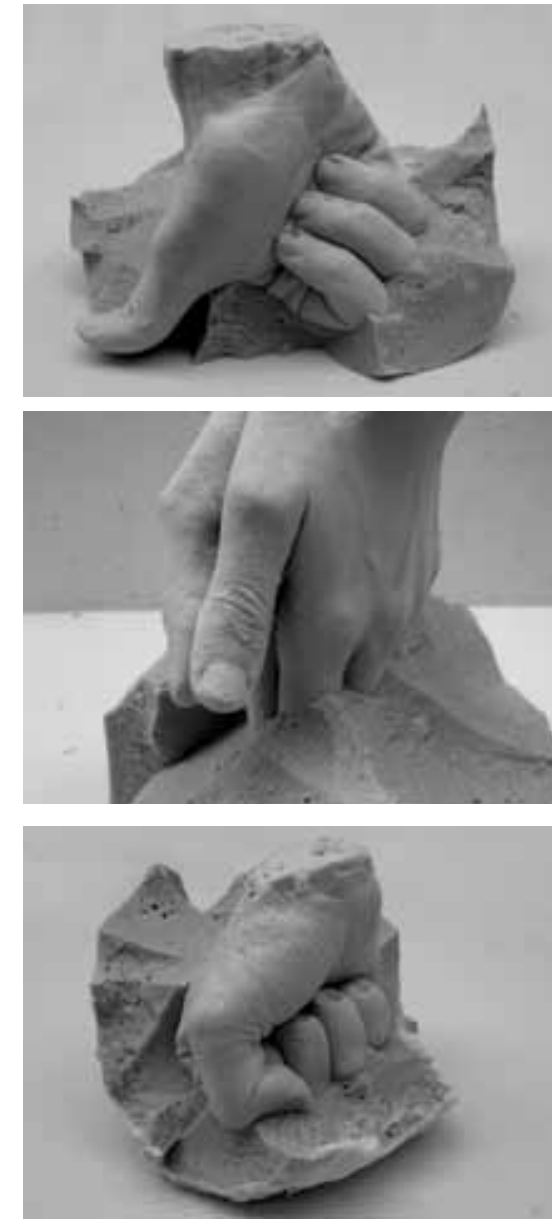

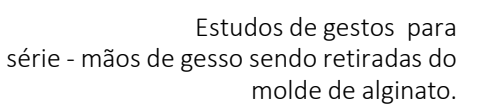


"POSITIVO" (2019) é uma instalação de parede constituída pelo objeto-mão replicado em resina transparente e por sua distribuição linear e simétrica na parede. Nessa ocasião, 10 objetos25 centímetros entre cada, formando uma dimensão de 2,25 metros de largura, 15 centímetros de altura e 20 centímetros de profundidade, com a barra aparente e distante da parede. 



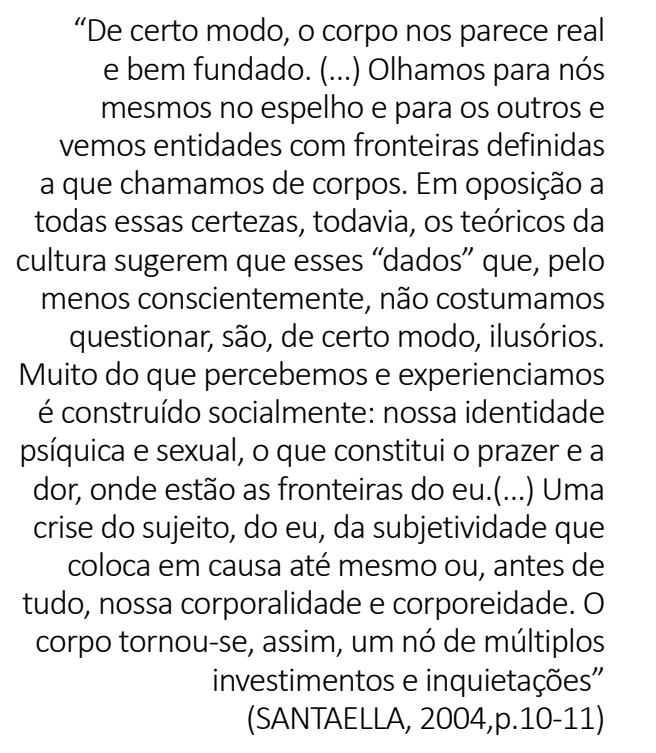

gesto produzido a partir do corpo além de retomar a questão dos códigos que modificam

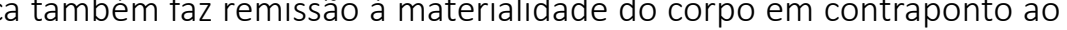
desaparecimento da presençą material a partir das relaçōes virtuais.

A imagem fotográicica sugere um objeto que vai desaparecendo no horizonte do enquadramento, sugerindo uma expansão do trabalho que se manifesta pela repetiç̃a do mesmo objeto-mão em linha reta, com intervalos simétricos na parede - ideia que se mantem como virtualidade do trabalho.

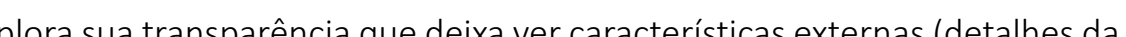
egrados por conta dessa transparência, (a) A incorporač̃o da barra ao objeto aponta para outros sentidos que vão ficando mals manifestos com o desenrolar dos trabalhos. Essas conexões deixam explicita a fragmentação do corpo (o corpo não está surgindo da parede), demarcam o encaixe, e assinalam para as possibilidades de encaixes e enxertos do corpo. Remissōes ao orgânico e ao inorgânico. A conexão aparente. 0 a em fragmento. 0 corpo enxertado. O corpo ciborgue.

A série tem continuidade com outros gestos e outras propostas instalativas ainda em desenvolvimento. Abaixo, seguem outros estudos de gestos em ensaio visual.

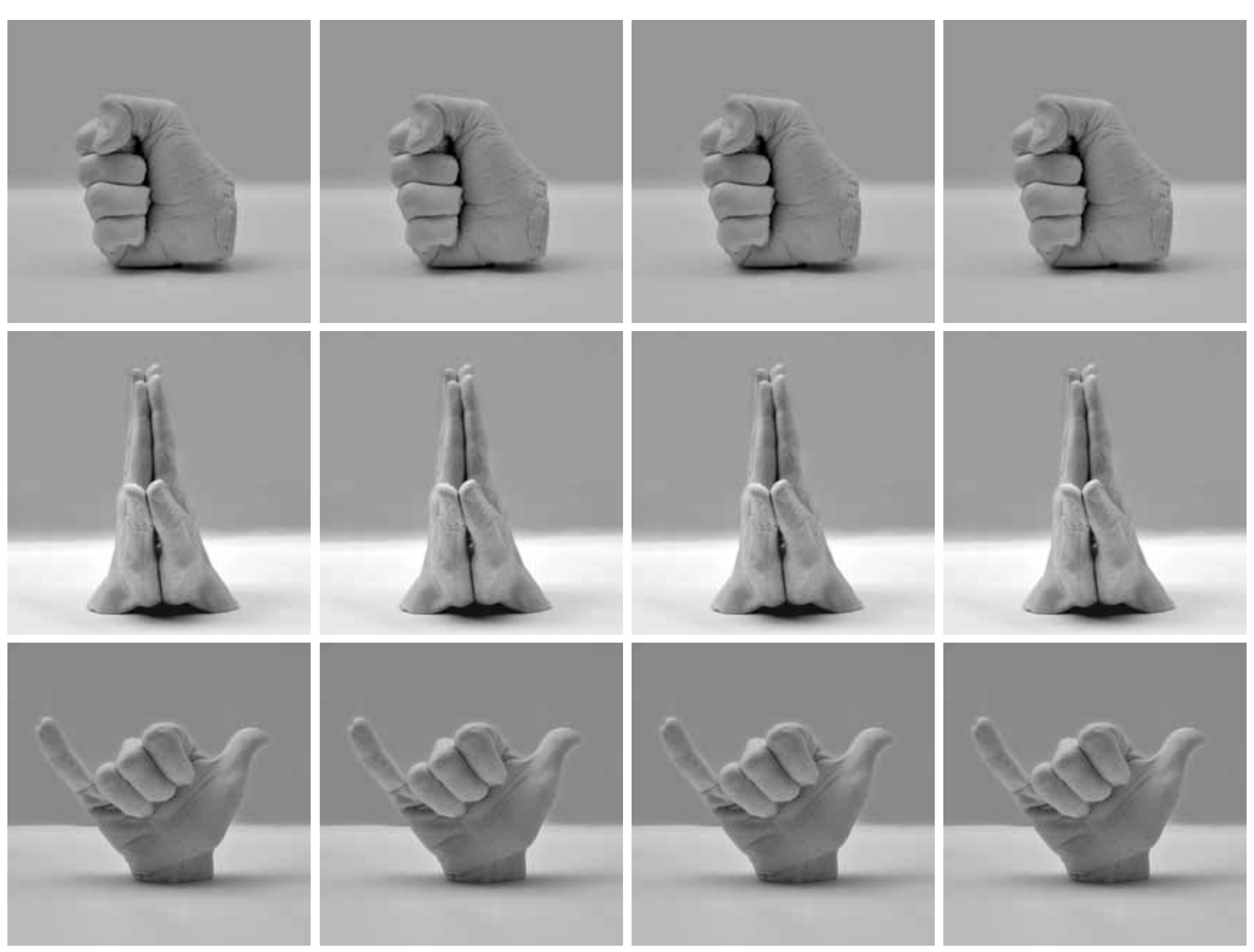

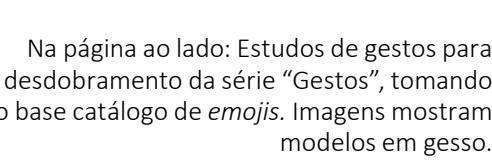


IV. só existo em terceira pessoa

"Só existo em terceira pessoa" compõe uma exposiç̧ão individual, realizada em outubro de 2019, na Galeria de Arte Fermanda Perracini Milani-espaço anero

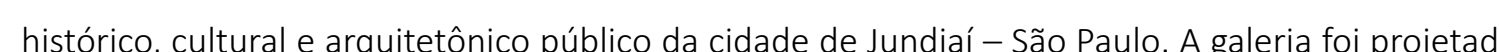
pela arquiteta Lina Bo Bardi ocupa um espace de 27 metros de conp

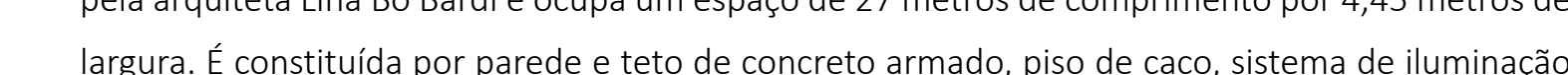

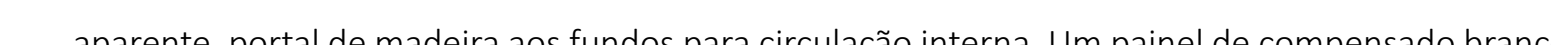

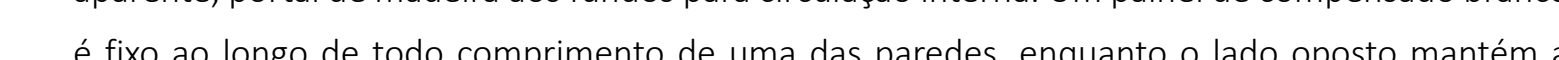
- estrutura orignal do teatro, com parede e collus de tijolo pintado de branco - a redor das

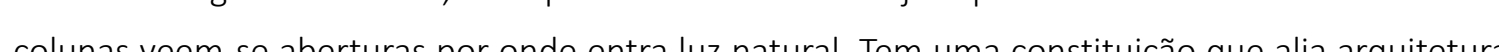
moderna à arauitetura antiga do teatro que data do início do século XX.

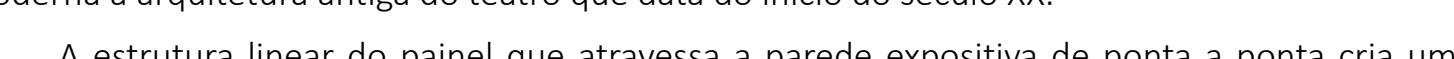

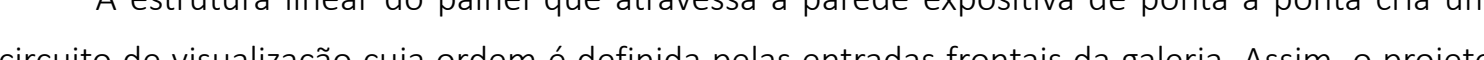
circunto de visual raçăo cuja ordem é defininda pelas entradas frontais da galeria. Assim, o projeto expostivo pensa essa lineandade do espaço, onde una coisa e vista depors da outra. Um texto

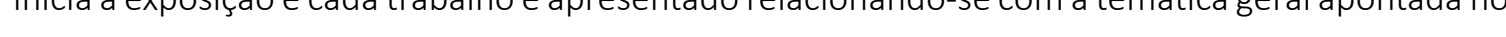
texto, construndo um dialogo com o proximo, e fazendo uma sobreposiçăo de pequenos sentidos que váo se acumulando trabahto apos trabaho.

- A distribuiçăo dos trabalhos no espaço pensa a passagem entre eles com intervalos maiores 

pensamento, entre 2016 e 2019. Seu titulo "So existo em terceira pessoa" traz a sugestão de um sujeito que se constrói a partir da relação com o outro, noçãa' que é tratada a partir do tema da autorrepresentação, tomando-a, em suas vias virtuais, como um dos acontecimentos marcantes da atualidade, que interfere especificamente na construção das subjetividades contemporâneasamplos movimentos de representação de si que fixam um eterno agora.

- 0 título também traz um dado constitutivo dos próntios trabahos em exposião, que

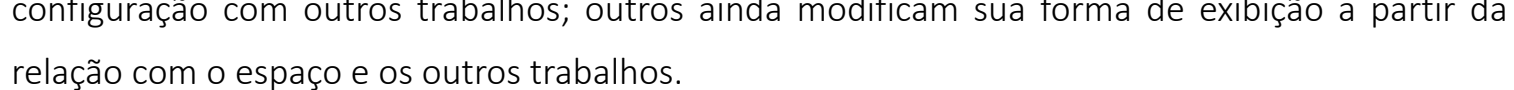

Proponho um diálogo entre 9 obras, penso quantidade e meios cruzando características Do local com a própria circularidade inerente ao tema da autorreopresentação, que traz sempre o elemento repetitivo do rosto. Por um lado, indico um fluxo de visualização que mescla linguagens diferentes, proporcionando experiências sensoriais visuais, espaciais e tatelis - podendo provocar ainda um pensamento sobre as proprrias tecnicas de produção engendradas. A fotografia. 0 video. A instalação. 0 objetto. 0 texto. Por outro lado, faço um jogo de trabalhos que mostram e escondem esse fragmento de corpo hiperexposto que comunica: o rosto.

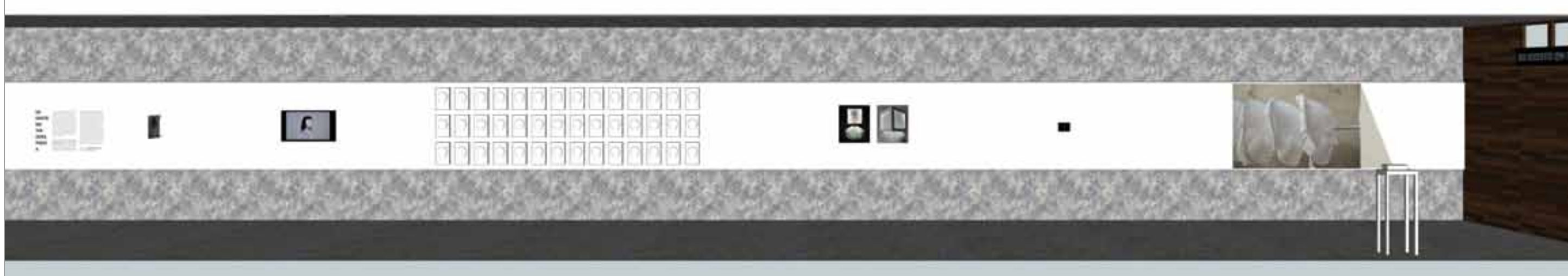


Um díptico formado por 2 fotografias performadas, "SILÊNCII" (2017) e "CAPA" (2017), inicia a exposiçăo. Essa conformação em diptico foi pensada especificamente para a estrutura linear do espaço, apresentando essas imagens de forma perpendicular em um sanduíche de acrilico transparente levemente espelhado, dentro do qual cada fotografia se mostra de um lado. Nessa estrutura, as fotografias não podem ser vistas de uma só vez. A estrutura em díptico cria ainda uma relação entre seus conteúdos: a primeira imagem traz uma placa de gesso em frente ao rosto a a segunda traz o que seria seu resultado.

Ambas as imagens fazem parte de “APAGAMENTO" (2017), série de trabalhos composta por fotografias performadas e vídeo. Através de imagens do meu corpo usando objettos que escondem

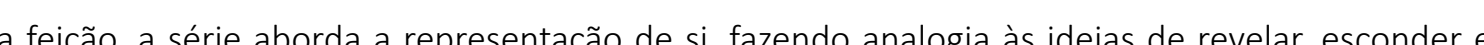
apar. Ten

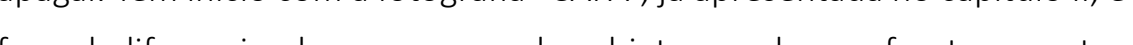

corpo escondido através de suas próprias máscaras mostra indicios de sua presenç̧a a partir das fotografias e da videoperformance "SIM, NÃO, TALVEZ", que segue na sequência, sendo apresentada em loop num monitor de TV posicionado a altura dos olhos

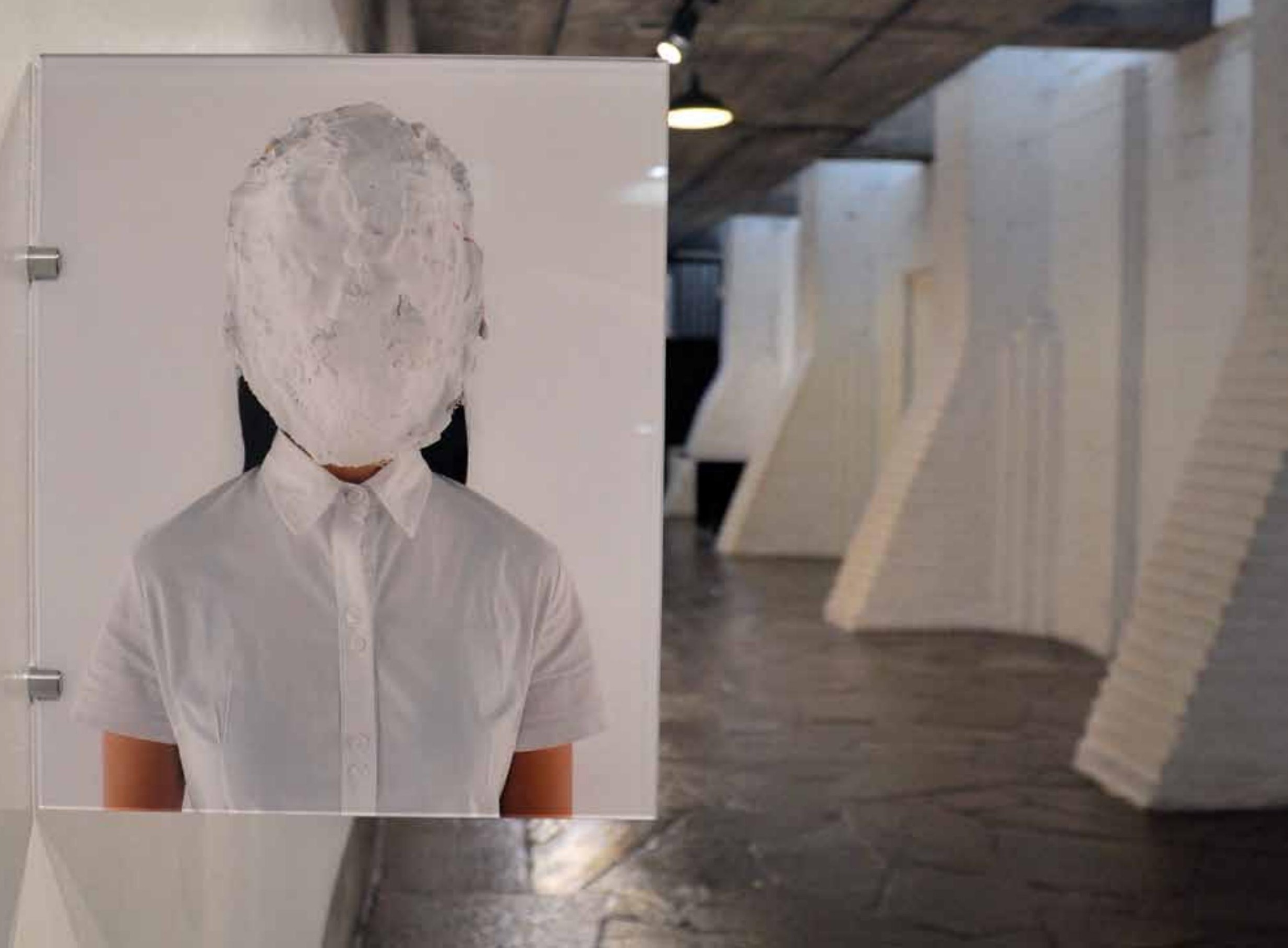




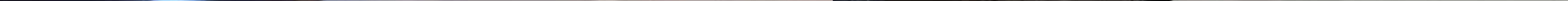




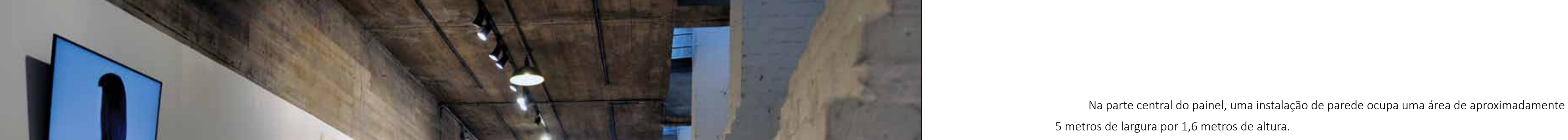
5 metros de largura por 1,6 metros de altura.

"REGISTRO" (2018) é uma instalação composta por 39 placas de gesso feitas a partir de um mesmo molde do rosto. Cada placa tem o tamanho de 30 centímetros de largura por 40 centimetros de altura e 2 centímetros de espessura, remetendo ao formato das fotos $3 \times 4$ de documentos de identidade.

O trabalho só existe na relação com o espaço. Os rostos são centralizados nas placas e razem a mesma expressão dos ou simetricamente em una formando un bos fect 3 linhas e 13 colunas, com d por um lado, os murais e pain

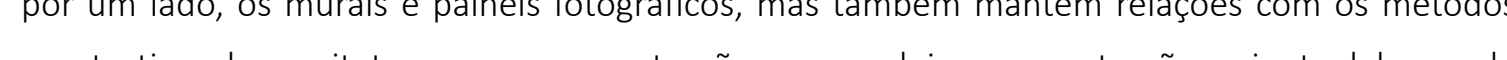

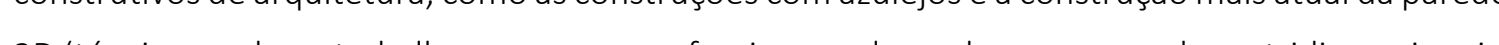
30 (teénica usada notrabahoem quese confeccionam placas de gesso en relewos thimensionais, reproduzidas em série, que são aplicadas lado a lado em grade na parede). Uma marcação em grade è feita no espaço. Depois, cada placa e montada com 2 parafusos que ficam aparentes, fazendo parte da estettica do trabalho. A marcaçăo è retirada, restando como desenhovazado entre as placas.

Emin

O corpo impresso no objeto. A escala corporal. A placa 3×4. 0 sorriso para a foto. 0 rosto centralizado na placa. 0 enquadramento do corpo. A formatação. O rosto que sai em relevo do objeto. Os detalhes do corpo no objeto. $\mathrm{O}$ rosto frente a frente com quem olha. $\mathrm{O}$ rosto visto por cima. $\mathrm{O}$ rosto visto por baixo. $\mathrm{O}$ rosto visto em sequência. $\mathrm{O}$ mesmo rosto anônimo multiplicado e aderido à arquitetura do espaço 


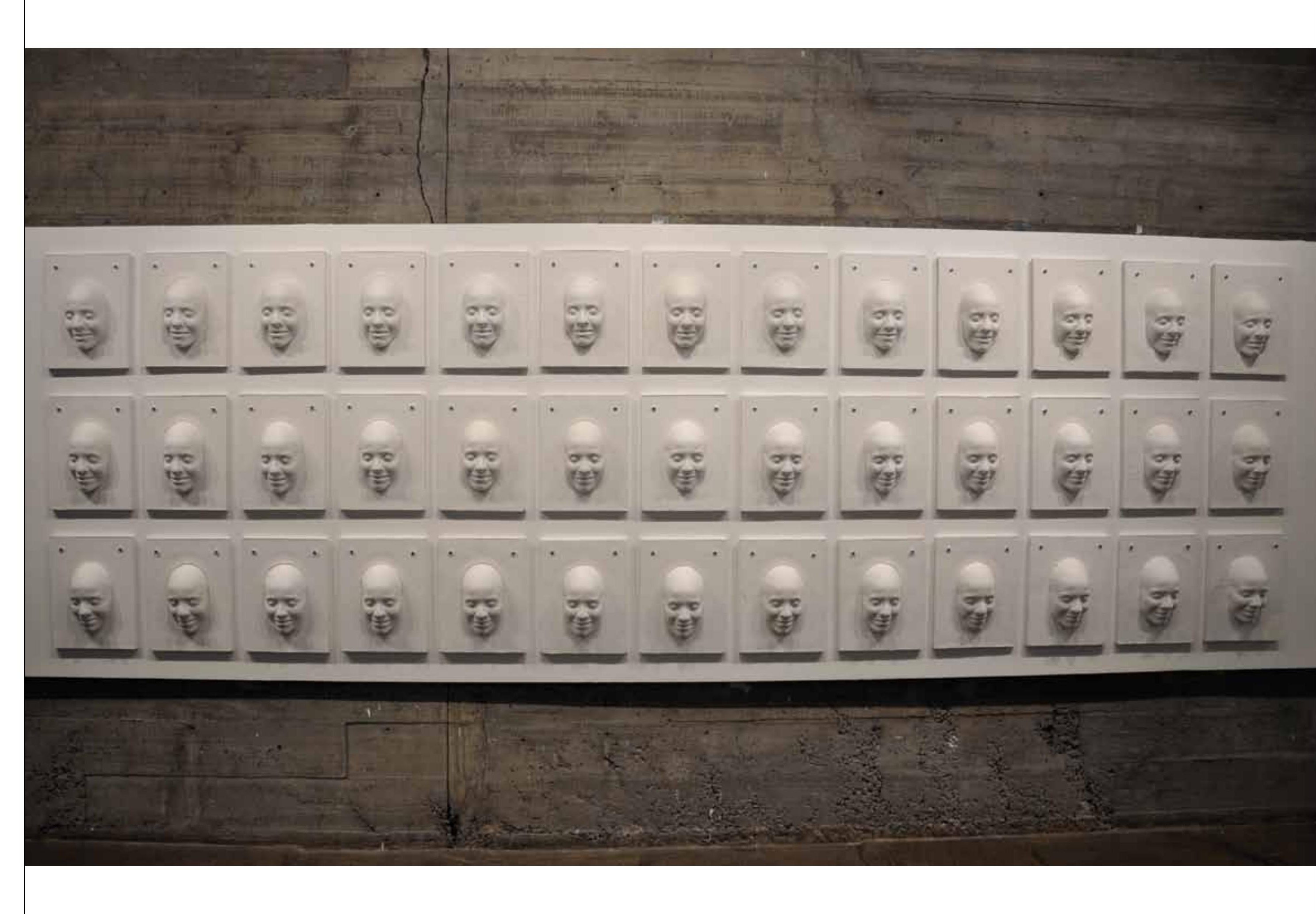




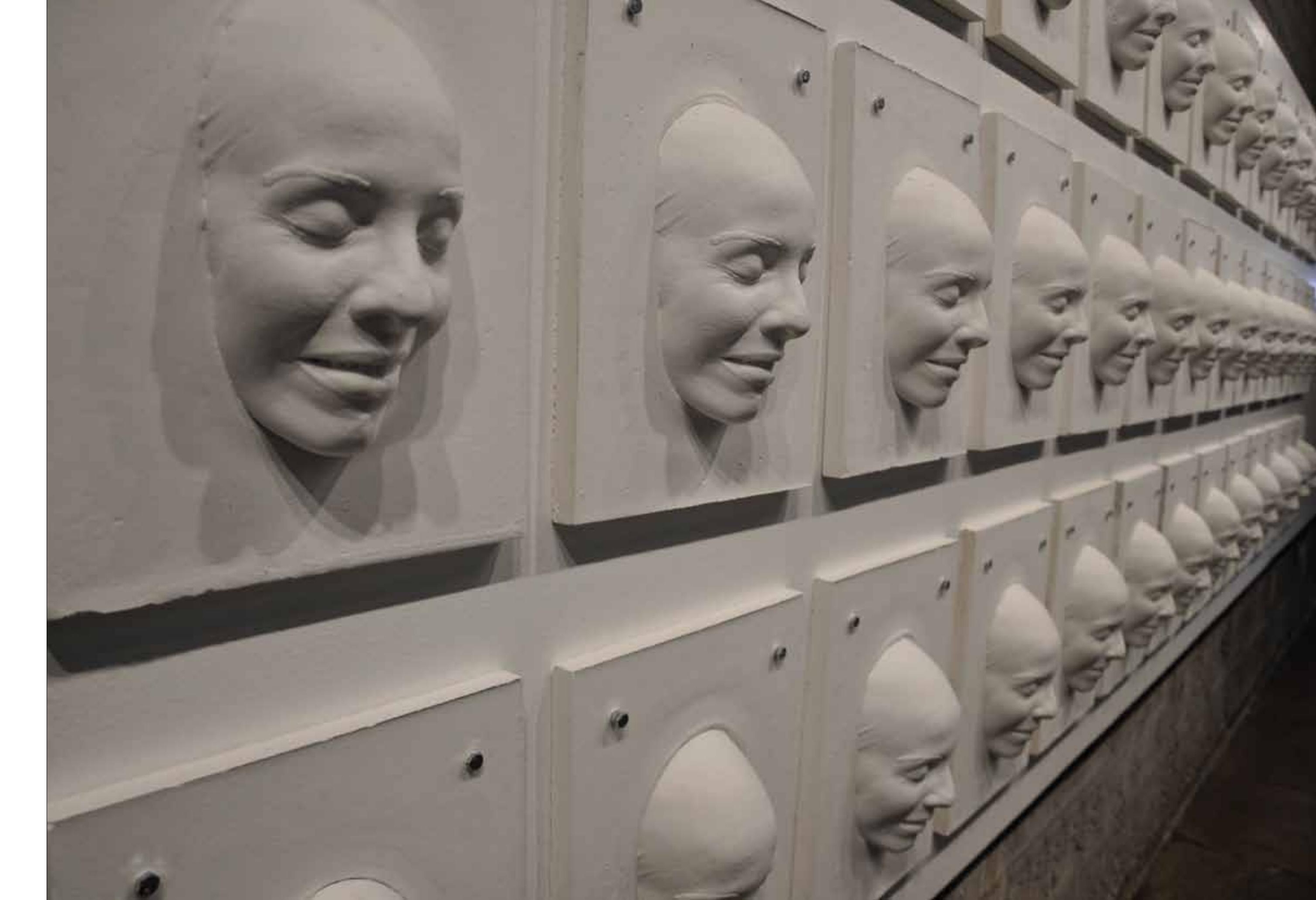


Ate essa parte da exposiç̧ão, o corpo evisto em fragmentos, cortado e enquadrado na imagen de partes do corpo, o rosto esta sempre arras de um objeto. Mesmo que seja tomado como matriz para produção de alguns desses objetos, nas imagens, suas máscaras criam um distanciamento entre representação e corpo representado.

Em "REGISTRO", o rosto que estava por trás se apresenta sozinho, como objeto apartado do corpo, que toma forma e se mostra em detalhes no objeto. A manifestaça do corpo na matera gesso traz o elemento tátil do meio tridimensional. Outras experiências de fruiço.

O público caminha entre a multiplicação do mesmo Busca diferencas. Che porto. Analisa os detalhes Observa se há algum "jogo dos 7 erros". Questiona a procedência dos rostos, se todos partem do mesmo molde, se todos têm a

$\mathrm{O}$ uso da repetiç̃a se refere simultaneamente a diversos aspectos. A multiplicação de um corpo pode ser vista hoje nas reproduções de imagens de si nos meios virtuais. Ao mesmo tempo, o corpo também está multiplicado na comunicação quando sua presença é diluída en diversas conversas concomitantes. Por outro lado, a repetiçăo do rosto em gesto de sorrir retoma tambèm um codigo do ato fotografico. A reproduçãa do gesto mecânico para a câmera se liga à ideia de um gesto esvaziado. Gestos que não falam da pessoa representada, mas de um código de comportamento. Reprodução e construção de identidad ${ }^{2}$.

A arquitetura da galeria, que se

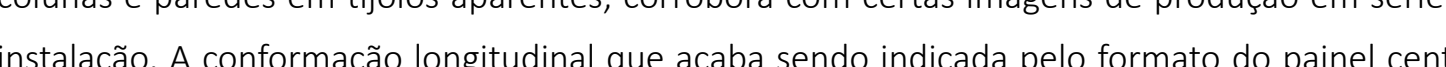
da parede também contribui para uma ideia de expansão e proliferação que a repetição indica. uso do gesso como matéria-prima, além de incorporar o material de construção à obra, e trazer imperféiçōes de produção, também remete a imagens mais antigas, referências anacrônnicas do uso
A materia gesso nas artes. Anacronismo. Ambiguidade.

A técnica de moldagem do rosto se inicia de uma tentativa de verossimilhança entre o real e o que está sendo representado, em busca do que não tem como ser dissimulado, pois em contato direto com a pele. Essa mesma técnica que aciona o contato com o real também cria a possibilidade da reprodução em série do objeto-rosto moldado. Apesar de ter marcado nesse molde todos os traços e detalhes de um rosto, sua reprodução em uma mesma cor e a montagem em grade nivelam e homosenéżm a informaçã. Esse rosto rindo multílicado na matéria gesso, que se acopla à parede branca do espaço, sugere também um rosto anônimo sem identidade ${ }^{3}$. entre corpo objetos-cabeça da instalação. Nos trabalhos que seguem, a imagens assumem uma dúvida maior entre realidade e ficção. Trazem aspectos que podem confundi-las com imagens produzidas digitalmente.

Outros 3 trabalhos da série “APAGAMENTO" são apresentados nessa sequência: 2 fotografias performadas 1 1 vídeo feito também a partir de fotografias performadas. As primeiras são ampliadas de forma a deixar a imagem do corpo em tamanho real. O vídeo diminui a escala corporal em sua apresentação em Ipad.

Ambas as imagens partem de uma mesma configuração e trazem novamente uma relação entre corpo, câmera e objeto. Nelas, o rosto aparece dentro de um cuboluminoso transparente que, alem de ser posicionado de formas derestes, va mostrando gradualmente distritos momentos de iluminação. A forma do cubon do corpo em quadros, quase replicando o próprio enquadramento da câmera. Pela transparência do material, vê-se o corpo por dentro, porém, sempre velado pela movimentação da iluminaçãa interna que mostra diferentes momentos entre o acender e apagar.

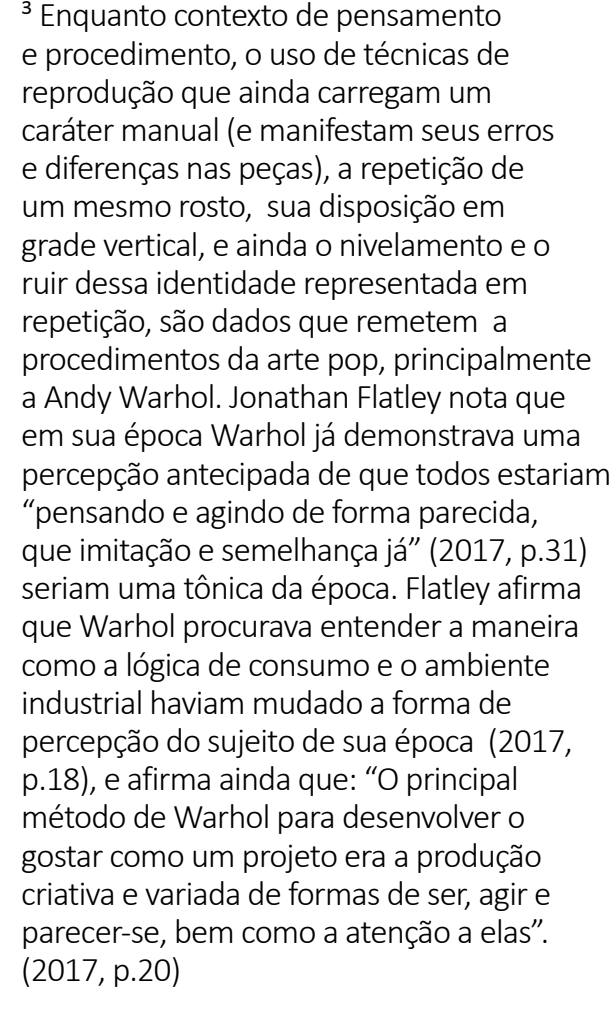


"LAPSO" (2017) traz a parte superior do corpo de frente centralizada na imagem e a cabeça corpo e quase deixa ver um rosto. "ENQUADRE" (2017) traz o mesmo corpo centralizado na imagem, porém, a cabeça não está encaixada na parte visivel do cubo, ficando suas quinas posicionadas ao centro do rosto. Ambiente e cubo trazem a mesma iluminaç̃o,o, sem que seja possivel ver algo internamente.

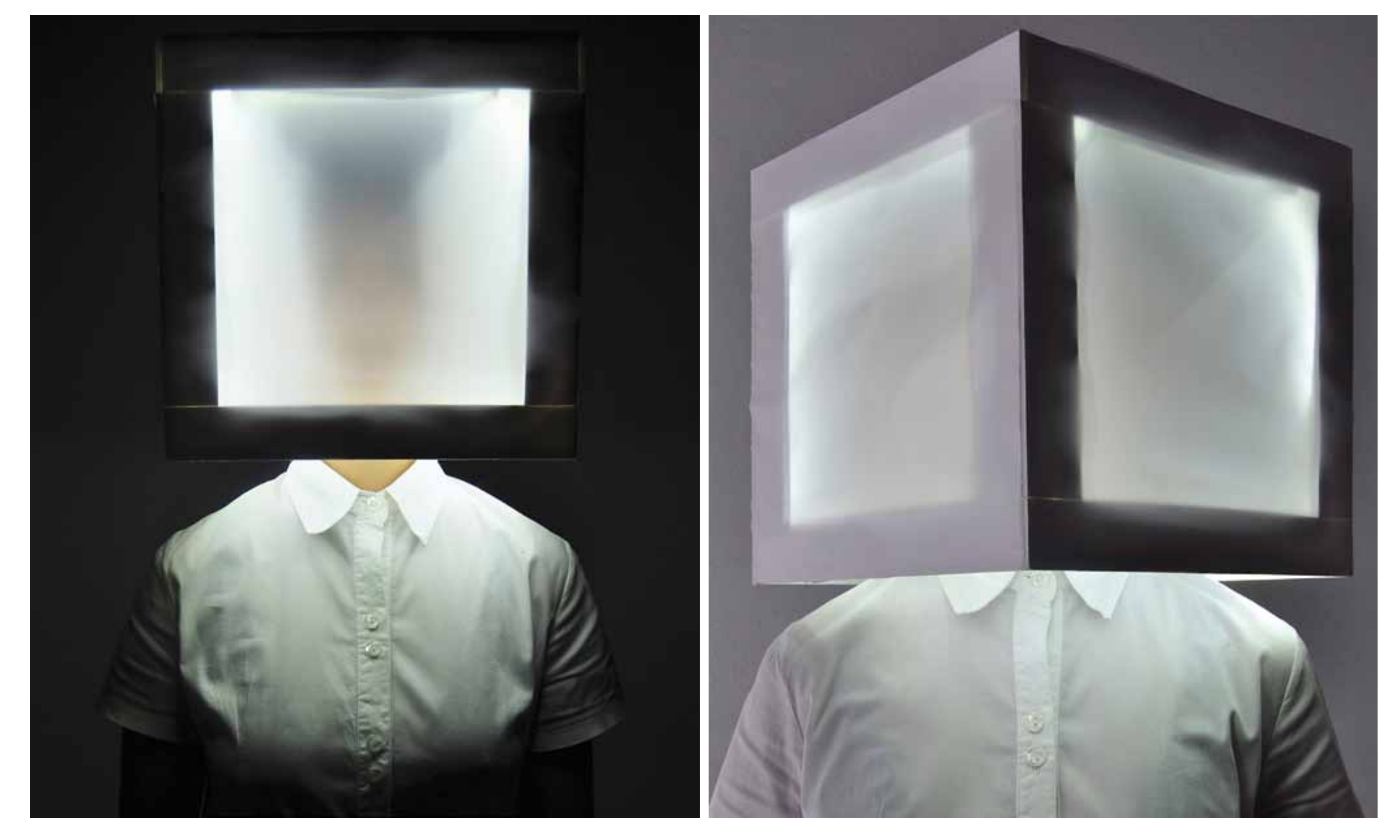


${ }^{4}$ link para vídeo: https://vimeo.
com/222100463

“CLARÃO" (2017)e é um vídeo criado a partir de 7 imagens em que o corpo agora é posicionado de lado para a câmera, com a cabeça novamente centralizada e o ambiente escurecido. A sequência de imagens simula um movimento fictício de luz a partir da iluminação interna do cubo. Num primeiro encadeamento, 2 imagens se repetem alternadamente mais de 70 vezes, com tempos descontinuidade que remete a um curto-circuito. Em seguida, uma sequência de 5 imagens se intercala. De forma repentina, a luz se impõe ofuscando a visão. Logo, a imagem segue no mesmo movimento oscilante e de baixa luminosidade. Vê-se que há um rosto por dentro do cubo. No momento em que esse rosto está prestes a aparecer, acaba sendo ocultado por um excesso de luz que toma o espaço e vai apagando algumas das formas delineadas.

A maneira de exposição do vídeo, em Ipad, reduz a escala do corpo e também tem a intenção de aprofundar o suspense da imagem. Com a escala reduzida, a oscilação principal do vídeo tem uma luminosidade tão baixa que só é vista caso se preste atenção. Caso passe despercebido, 0 público pode ser surpreendido por um clarão no monitor, que logo some novamente. Então, ao passar e ver esse clarão, o público pode ser chamado a prestar atenção no vídeo. Contudo, a própria revelar e esconder. O clarão é tão rápido que chama pela espera do próximo, com o intuito de se ver melhor. Porém, os próximos clarões provocam a mesma sensação de impossibilidade de capturar a imagem. Nesse movimento de luz, esses trabalhos retomam o título da série, "APAGAMENTO", que se refere a um momento no qual o ato de se fotografar, ao invés de contribuir para a exibição, parece colaborar mais para uma ideia de ocultamento.

$152 \mid$ 


and


Todos os vídeos mostrados no texto são realizados com a mesma técnica de simular se assemelha tanto a imagens iniciais do cinema, em que ficava clara essa passagem do rolo de imagens do filme (que também marcavam os movimentos corporais), mas ao mesmo tempo remete também ao GIF animado (Graphics Interchange Format), que é um tipo de animação curta, que pode ser feita por aplicativos nos próprios celulares, cujo uso crescente está muito associado às redes sociais e ao uso de dispositivos móveis nas últimas décadas.

"FLUXO" (2018) sé mais um dessesvídeos, realizado com sequêcias de movimentos criados (n) é perfurado ao centro
passagem de uma barra

Num fundo de parede externa irregular, cheia de marcas do tempo e leve manifestação de vegetação musgosa, a imagem mostra uma barra rosqueada que a corta de ponta a ponta horizontalmente, se localizando acima do centro. Numa movimentação lenta e mecânica, cabeças de gesso fixadas na barra vão entrando e saindo da imagem da esquerda para a direita. São mostradas quase no limite da imagem. Todas exibem a mesma expressão, porem, cada uma traz uma marca de desgaste no material. As cabeças param e se acumulam da esquerda para a direita. Depois voltam a passar no sentido oposto. 0 ciclo de repete continuamente.

O video é projetado no painel da parede tomando todo seu espaço vertical. 0 tamanho do corpo é ampliado. A cabeça toma um tamanho desproporcional ao recuo do espaço. 0 público passa e projeta o corpo para trás para olhar a imagem. 


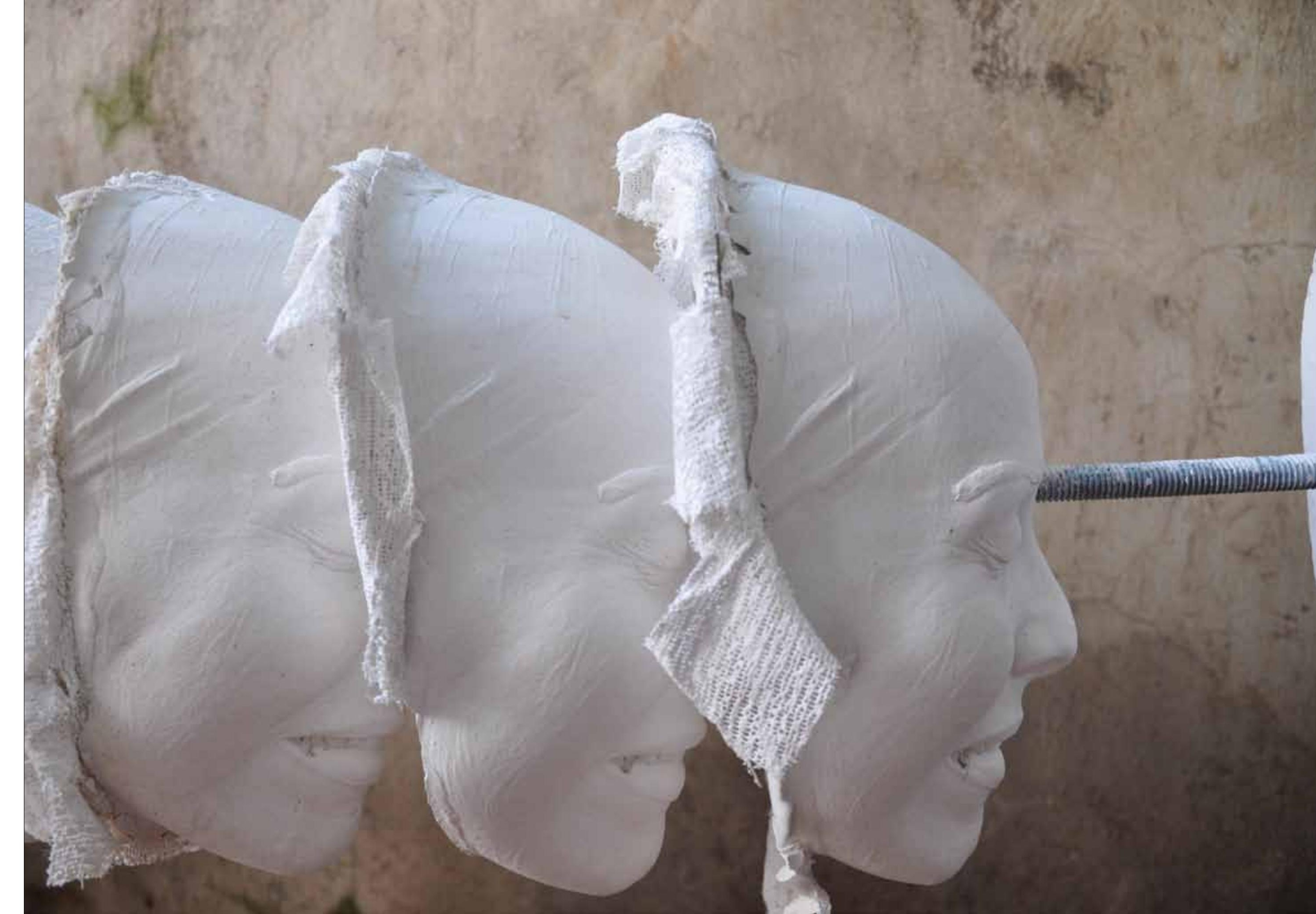




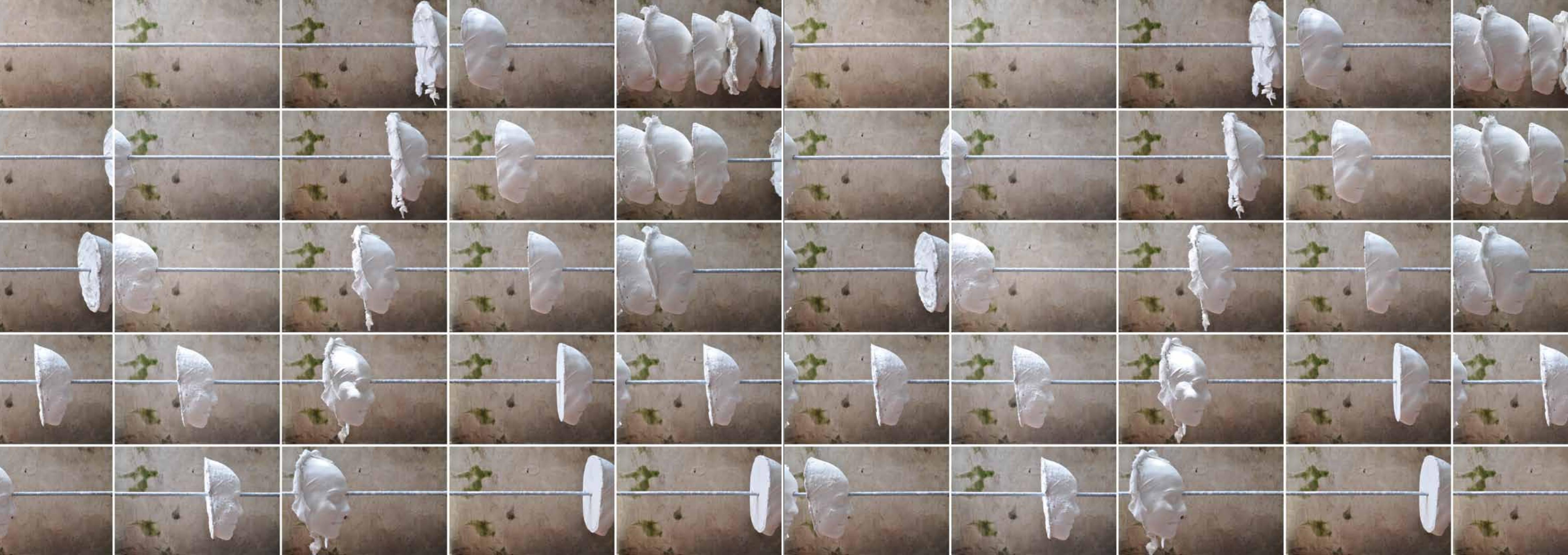



O corpo hiperexposto. O rosto que está por trás do objeto. $O$ rosto que está por trás da imagem. 0 rosto em fragmento. 0 corpo mecânico. 0 corpo domesticado. 0 corpo apropriado. $\mathrm{O}$ rosto multiplicado. $\mathrm{O}$ rosto que se insinua no espaço. $\mathrm{O}$ rosto em detalhe no objeto. $\mathrm{O}$ rosto tátil. 0 rosto esvaziado na repetiç̆o. 0 rosto em escala corporal. O corpo enquadrado. O corpo limitado. O corpo-objeto. O rosto eclipsado. O corpo fora de escala, ampliado ou diminuído. 0 rosto atravessado $\mathrm{O}$ rosto invadido. $\mathrm{O}$ toque. $\mathrm{A}$ viš̃o- $\mathrm{A}$ formando a partir de todas essas imagens em sequência.

\section{origens}

"Só existo em terceira pessoa". Se numa vis̃a geral essa frase vem falar da constituição da subjetividade a partir da relação com o outro, no contexto especifico em que esse texto se apresenta, ela retoma a voz em terceira pessoa - prerrogativa do texto cientifico e acadêmico. Construção de neutralidade e distanciamento em relação ao objeto de estudo. De certa forma, construçãao de corpo anônimo. Apagamento do sujeito que fala.

O discurso aqui se apropria dessa voz. A voz em primeira pessoa se estabelece a partir da voz em terceira pessoa. Construçăo de subjetividade. Olhar para si como outro.

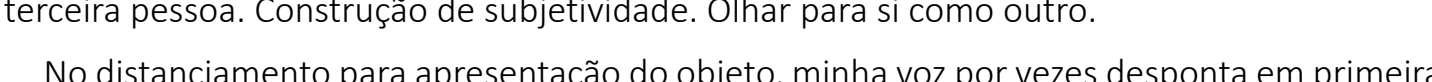
pessoa. Apresento as experiências que interferem e encaminham processos. O corpo continua

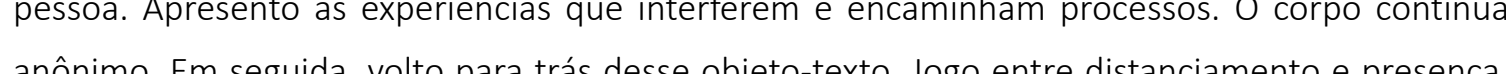
anônimo. Em segulda, volto para tras desse objeto-texto. Jogo entre distanciamento e presençąa.
Mascaramentos.

Nesse exercício de escrita, otexto central de apresentação dos trabal hos se afirma na estrutura primordialmente descritiva- gênero de composição textual que representa detalhadamente algo, mantendo relaçăo entre objeto representado e representaçăo verbal. Em sua autonomia, cria mitmos e fentos, trazendo em sua propra estrutura outros aspectos dos trabah hos apresentados. neutralidade, funcionalidade, objetividade, precisāo, produçăo de excesso, repetição, circularidade, monotonia, dispersão, fragmentação, ironia, comicidade, ambiguidade, simultaneidade,

Mantenho essa mesma estrutura do início ao fim. A maneira descritiva aqui traz redundâncias, informaç̃oes que parecem desnecessárias, disfuncionais, que num olhar inicial podem gerar dispersão. Contudo, a depender do olhar de quem busca esse texto, essa mesma estrutura também 
procura outros lipos de reverberaçóes e, por isso, assume o excesso, a repelçăa, a monotonna a a circularidade de alguns tipos de trformaçoes (que são tambeem caracteristicas dos trabalhos).

Decido trazer um conjunto de trabalhos e proposiçōes que tangenciam uma temática e não toda produção do período. Vou cercando o tema da autorrepresentação a partir da leitura de cada proposta em andamento, ou cada trabalho finalizado, criando corpo e densidade a partir do conjunto todo.

Em cada capítulo, o texto vai apresentando os trabalhos de forma fragmentada, formando imagens mentais, pouco a pourco, de maneira deccritiva Desenhos, projetos imagens fotografites de processo vão se vin vion As e montagens fotorgáficas buscam ainda un

As reflexões e os diálogos teóricos em notas apontam um encaminhar de pensamentos que reverberam na elaboração dos trabalhos. Ás vezes estão mais evidentes nas propostas, outras apontam para horizontes e desdobramentos da pesquisa. Ambas as colunas de texto vão construindo sentido em conjunto e sua diagramação em paralelo reflete certa simultaneidade do fluxo de acontecim en conjunto e sua diagramaçăo em paralelo reflete certa simultantida do do O capitulo "um, primeiro, anterior" aborda somente "Incubadora", trabalho hibriduo entre instalą̧ăo e performance realizado antes do doutorado, que cria uma base para a compreensio do desenvolvimento. Considerando seu tempo de elaboração alongada nos anos, que possibilitou vários testes, experimentaçoes, incorporaçāes de elementos e exclusão de outros, esse capitulo vai trazendo aspectos bem detalhados, apontando ainda para outras ideias não realizadas.

Vou apresentando a elaboração do trabalho, seguindo a maneira como o trabalho foi desenvolvido, passando pela criação das máquinas e elementos, pelo reconhecimento das relaçôes com espaço expositivo, pela observaçăo dos objetos-balão produzidos, pelo pensamento do corpo en relaçăo com a maquina e da relaçāo com o pubbico. Insiro desennos tecnicos e projetos graficos que mostram uma maneira projetiva de concepção desse trabalho, projetos que esbarram no pensamento arquitetônico ou do design de objetos. Tento não adiantar aspectos que serão vistos nas imagens em sequência. Então, lanço uma série longa de fotografias de registro do trabalho isoladamente, sem legendas, Deixo essas imagens trabaharem sozinhas, falando por si durante algumas páginas. Depois disso, produzo outras reflexões.

A partir das notas desse capitulo, vou criando diálogos com teóricos que abrem uma ( como o corpo também vai se informando e estabelecendo outros ritmos e maneiras de operar e pensar a partir dessas relaçoes; os procedimentos artísticos que criam formas de relação entre orgânico e inorgânico.

"Incubadora" evidencia na minha própria prática esse interesse na relação entre corpo e produção, numa prática que extrapola os limites do corpo pela reprodução em série e por isso vai criando artificios para mediar sua concretização. Ao criar uma nova relação entre corpo e produção a partir da máquina, todo o interesse do processo vai se voltando para pensar essa imbricação entre corpo e tecnologias, que cria padrões não apenas para os objetos produzidos, mas para os próprios corpos que produzem. Assim, vai-se pensando essa circularidade da relaçăo entre corpoprodução-tecnologias-objeto, onde não se sabe mais quem está subordinado a quem nesse ciclo. Fica no ar uma dúvida sobre a objetificação ou alienação desse corpo, problemas tematizados nos trabalhos seguintes.

Em meio a esse interesse pelo corpo em seu entrelaçamento com as tecnologias, que vai se complexificando com o tempo, nos próximos trabalhos, incorporo o tema da autorrepresentação à minha prática. Considerando sua i mportância atual como prática coletiva, que também subentende 
algum tipo de mediação entre corpo e tecnologias, pois que é alimentada pelas relaçoes nas redes sociais, penso a construçăao da subjetividade a partir de um processo de reproduçãao de códigos de comportamento.

Para esses trabalhos, parto de meu corpo conceitualmente para abordar as questoes de autorrepresentaç̧ão, mas não pretendo falar de suas características específicas, tendo mais interesse em observar codilos ave informam a construçäo de subjetvidade hoje de geral- buscando outros corpos e outras situaçoes que justifiiguem novas articulaạoes

No capítulo dois "corpo matriz", ppresento uma transicão do processo crativo ao incoporar

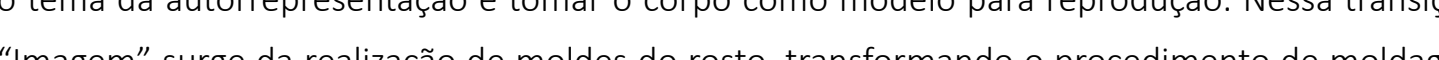
(a) (T)

oldagem do corpo também são feitas as máscaras usadas em todos os trabalhos do capitulo. "CAPA" é uma primeira fotografia performada que toma como parâmetro de construçăo da imagem os códigos da fotografiia de identidade, códigos que pretendem neutralizar as informaçóes do ambiente e do individuo, e formatar o comportamento do corpo de frente para a câmera; códigos que, por seu uso corrente, ficam quase invisibilizados como parâmetros de construção. "CAPA", então, marca padrōes formais para construção dos próximos trabalhos, numa autorrepresentação que pensa o rosto como máscara. 0 corpo vai sendo fotografado com suas máscaras colocando em questão a ideia de verossimilhança tanto das autorrepresentaçōes, quanto do próprio meio fotográfico.

Nos videos apresentados nesse capitulo, sua construçăa traz um duplo movimento ambiguo e irônico de analogia e simulação, interferindo na imagem orgânica do corpo. Os vídeos são formados a partir de sequências de fotografias performadas simulando movimentos corporais que acabam artificiais e mais aproximados aos movimentos mecânicos e "maquinicos". O corpo lante da cảmera, controlado por seus tempos e funcionamentos, e as imagens desse corpo em ovimento, criadas artificialmente.

Em "objeto indice", trago trabalhos que pensam a desmaterialização do corpo e sua transformação em objeto. 0 corpo que tinha presença na performance, que se mostrava nas imagens com suas máscaras, agora tem seus fragmentos fixados na matéria, apresentados como objetos no espaço. Há uma transferência de materialidades, onde o corpo se manifesta como indice no objeto exposto. Seus fragmentos são literalmente fixados e transformados em objetos. Nesse capitulo, exponho muitos trabalhos em desenvolvimento que visam experimentar as (1) diversas relaçōes do obj também elementos da própria arquitetura na constru

Seguindo uma dinâmica tipica das experimentaçōes e testes, de montar, observar e desmontar as propostas no espaço, de colocar e tirar elementos, o texto, aqui, segue uma rítmica mais acelerada. Busca criar densidade a partir do conjunto de proposiç̄ōes, observar aspectos gerais, assinalando alguns procedimentos, noç̃es e relaç̄es, ao invés de entrar demasiadamente em cada proposta, dado que ainda estão em desenvolvimento. Considerando a situação de residência, e a mobilidade eflexibilidade das açōes que se realizam num limite de tempo e espaço, trabalho com poucos tipos de materiais e elementos, assim como com procedimentos simples, estabelecendo diversas articulaçoes entre eles.

Um mesmo gesto éescolhido, gesto travado de sorrir, reproduzido centenas de vezes em gesso e exibido en duas formas. m sua toma original ou com um furocentral. Tes our tos elementos da

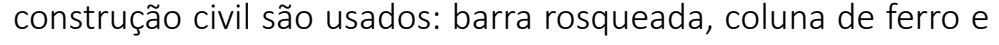
de montagem são testados: disposição, empilhamento, furo, encaixe. Por meio da articulação desses elementos e procedimentos testo vários posicionamentos do objeto no chão, na parede, na coluna, na barra, entre chão e teto, entre paredes. Vou vendo a relação com o corpo de quem observa: o objeto frente a frente, o objeto visto de cima, o objeto atravessado, objeto encaixado, 
o objeto visto na lateral, o objeto visto em todos os seus lados, o objeto multiplicado no espaço. 0 funcionamento da mesma expressão facial tambermé anal sado em todas as posiç̧ós, pensan do em possivivis outras expressões que se articulem melhor com esses posicionamentos.

Cada uma dessas propostas cria sua própria imagem, porém, algumas são mais recorrentes: fragmentação, reproduçăa, fábrica, corpo mecanizado, padronização, uniformizaçăo, planificaçāo, esvaziamento, ordem, controle, narcisismo, violência, morte, ruína. Em meio a esses testes, outros materiais vão sendo apresentedos dentro do capitub, apontando para novos desdobramentos A

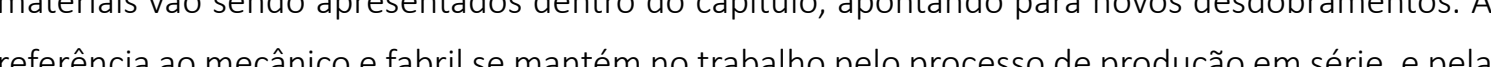
fixação da expressão no rosto. Todos os trabalhos, nessa situação, só se realizam na relação com o espaç̧, e incorporam o espaço à sua constituiçăa.

Oúltimo capítulo, "Śo existo em terceira pessoa", introduz o titulo desta tese falando desse corpo que se constrói a partir do outro. 0 texto toma um tempo mais fluido, criando diálogos entre o já apresentado, passando ainda por outros trabalhos. Na medida em que apresenta uma exposição individual trazendo algumas relações entre os trabalhos e o espaço, antecipa uma ideia de fechamento, assinalando para a situaçăo de que esses são alguns dos possivivis diálogos com determinado espaço expositivo, e determinado espaço de texto, que também podem se modificar depender de outras circunstâncias.

Inicio o texto falando sobre um processo artístico que em sua própria natureza carrega um dado metalinguistico, que vai tematizando suas operações ou as abordando em meio aos trabalhos. De forma direta, isso pode ser visto em "Incubadora" e "Imagem", que eram meios para produção de outros trabalhos e acabaram ganhando autonomia. Pode ser visto tambem nos trabalhos em que visto máscaras de mim e me fotografo, onde a verossimilhança da técnica fotográfica está em questão. A construção desse texto tambem o manifesta, segue um caminho descritivo, vai apresentando o processo e interferindo em sua leitura, criando ritmos e efeitos que espelham aspectos do desenvolvimento dos trabalhos, construindo sentido no conjunto de apresentaçōes e
Nesse tipo de atenção ao processo, em que os trabalhos vão se formando por dentro de um fluxo de acontecimentos, vou indicando no texto a maneira de elaboração, marcando interesses que motivam a produçäo, assinalando para possiveis dialogos teoricos, para que a leitura dos trabalhos também aconteça em fluxo. Com essa compressão que caminha com os acontecimentos, tenho também na elaboração desse objeto-texto origens para futuros trabalhos

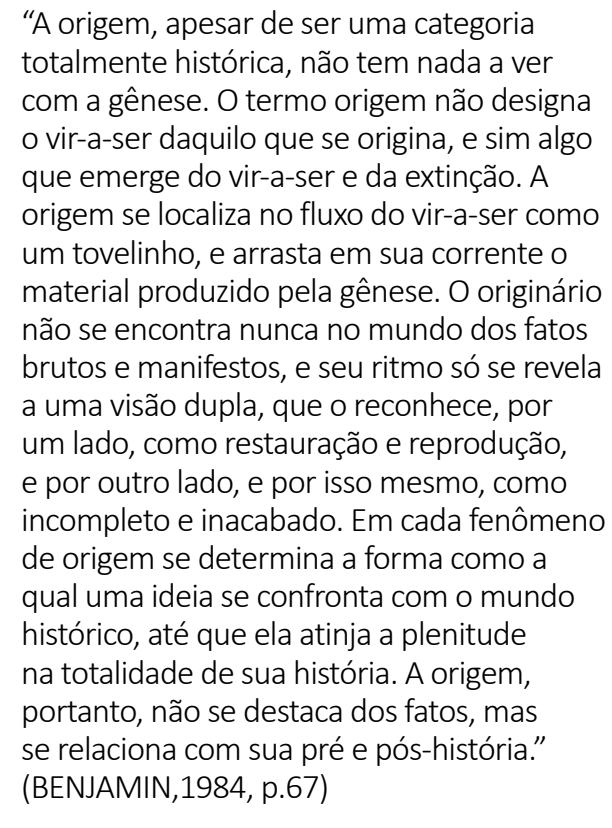


anexo I

fição científica artesanal

Como anexo, trago outro grupo de trabalhos - finalizados durante o doutorado - que se relacionam de outras manerias com o que foi apresentado e apontam ângulos diferentes do desenvolvimento do processo - os procedimentos de fixar um tempo na matéria, o pensamento estético de assepsia e acabamento, a relação entre orgânico e inorgânico, a relação com o corpo a partir do alimento, a catalogação de hábitos culturais.

\section{"NATUREZA-MORTA" (SÉRIE)}

Série de objetos instalativos composta por blocos de resina transparente dentro dos quais são encapsulados alimentos. Os blocos são expostos dentro de estruturas de metal iluminadas internamente.

Os maciços de resina transparente trazem alimentos úmidos que são encapsulados, criando um vácuo de ar que estabiliza o processo de decomposição. Os alimentos se mantêm da mesma forma depois que perdem o contato com o ar, podendo sofrer alteraçōes de cor e textura por causa da luz ou da movimentação do objeto. A série cataloga uma série de alimentos habituais na alimentaçăo brasilerra, trazendo referenclias tanto da na (como o prato feito), quanto caseiras (como o arroz e fejajo cozidos). Alguns tipos de ulensilios de armazenamento tambem fazem parte dessa catalogação, como potes de vidro, plástico (tap-ware) e marmitas de alumínio. Esses potes acabam cumprindo uma função tanto técnica para proteção do alimento e criação do vácuo de ar, quanto estética de representação de uma cultura contemporânea, dado que manifestam tecnologias atuais de armazenamento.
Os cubos de resina são expostos em estruturas iluminadas internamente, criadas especificamente para o trabalho. Odesenho dessas estruturas mostra um cruzamento de referências entre um mobiliário de escritório ou caseiro, e o de vitrines de restaurantes e lanchonetes com suas luzes para iluminaç̧ão dos produtos. O conceito para elaboração dessas estruturas parte da ideia de incorporar a base à obra, fazendo com que estrutura e objeto formem o trabalho final. A iluminação da estrutura, além de realçar o alimento e torná-lo mais atraente, cumprindo seu efeito publicitário, também evidencia ainda mais a flutuaç̃o dos potes de comida na resina, dando um caráter de flutuação.

0 títull da série relaciona o gênero da natureza-morta nas artes visuais a próprio

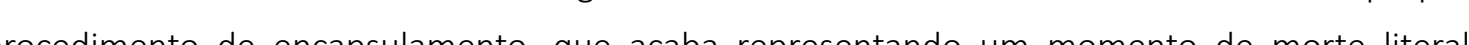



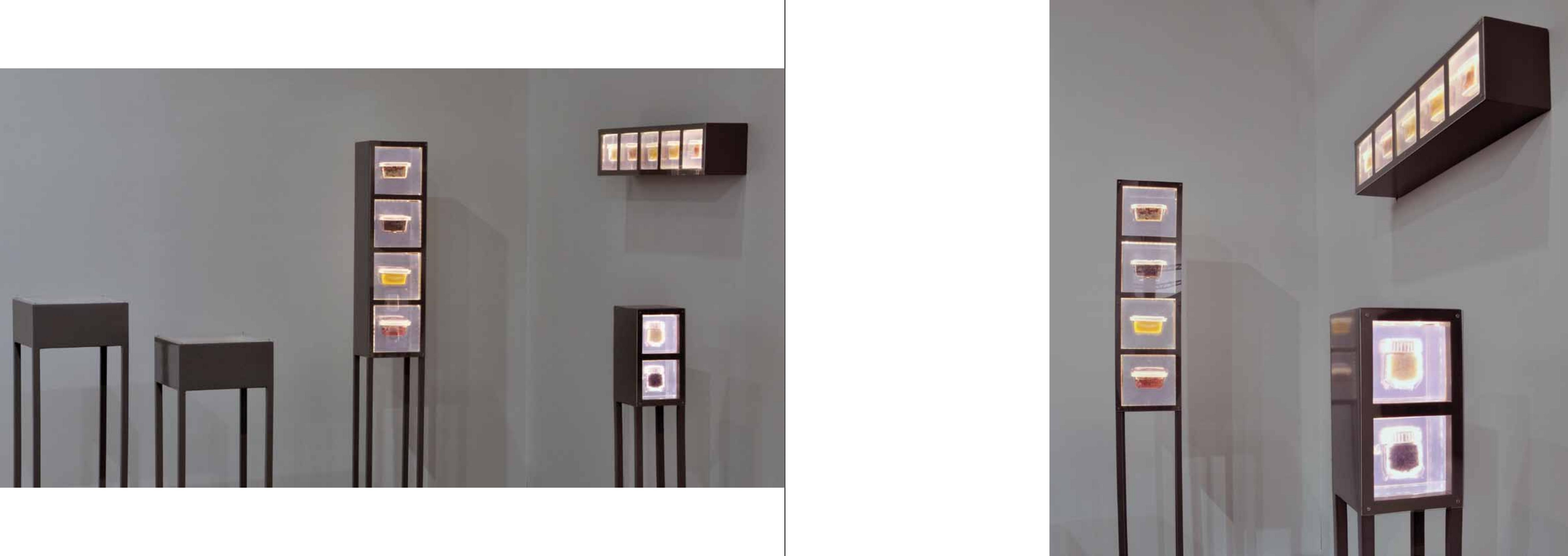

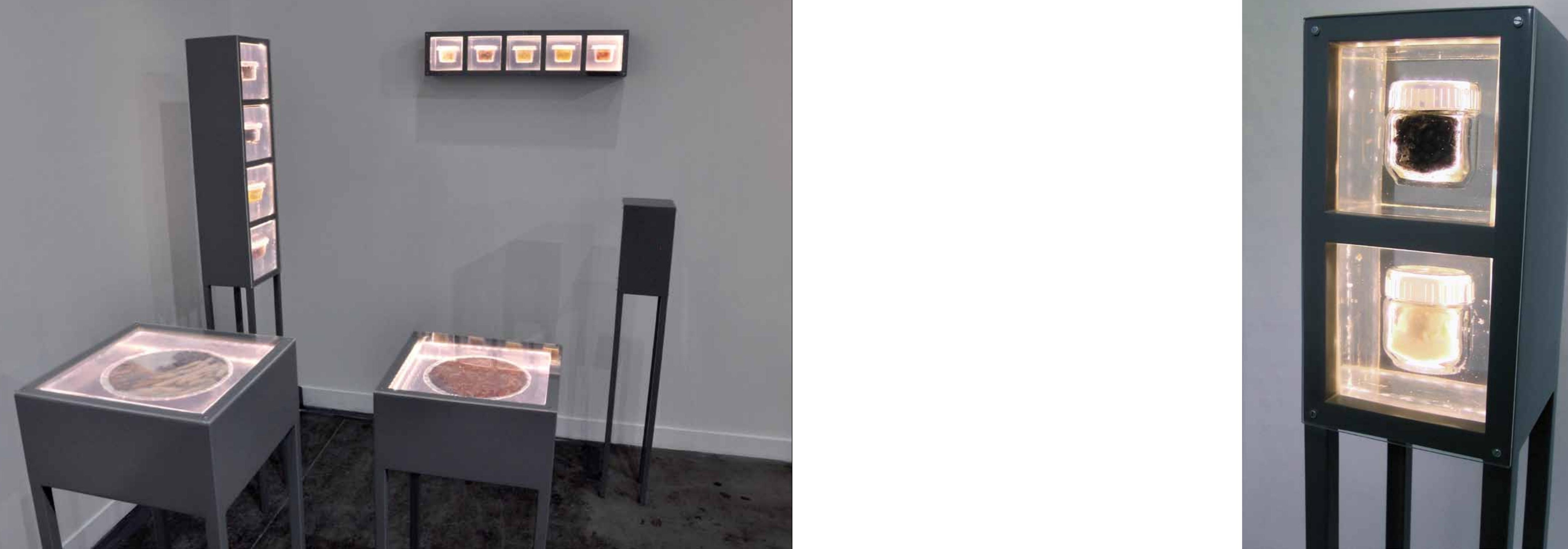

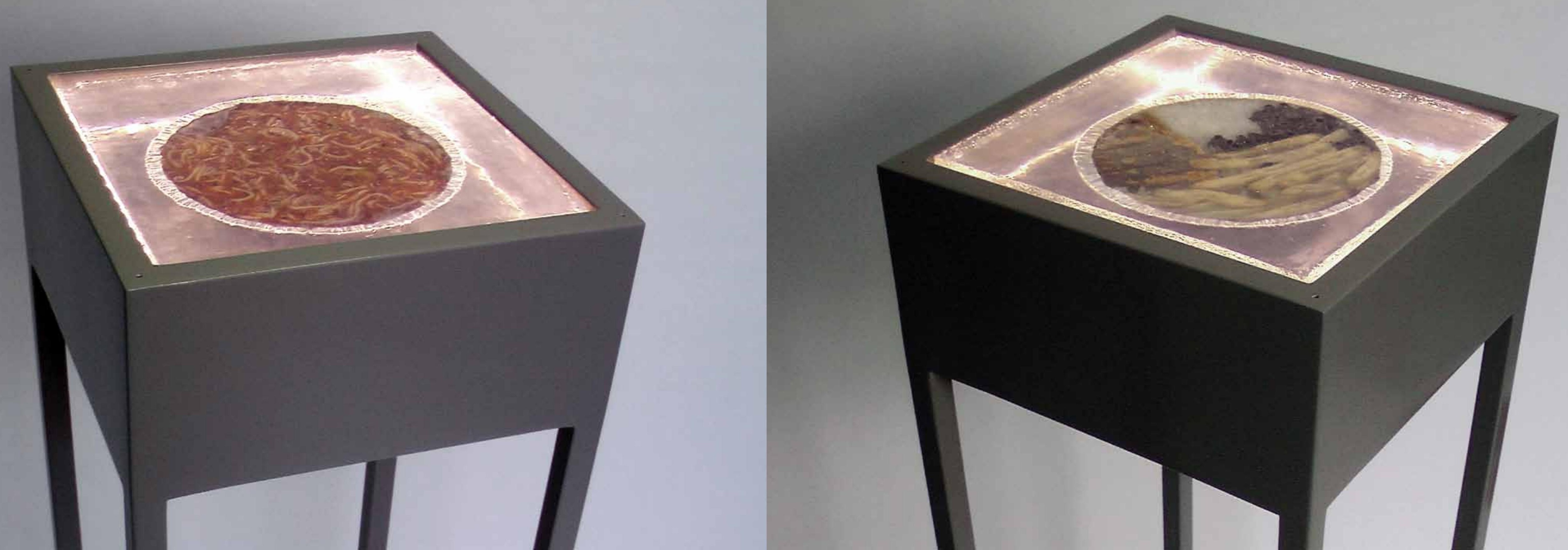


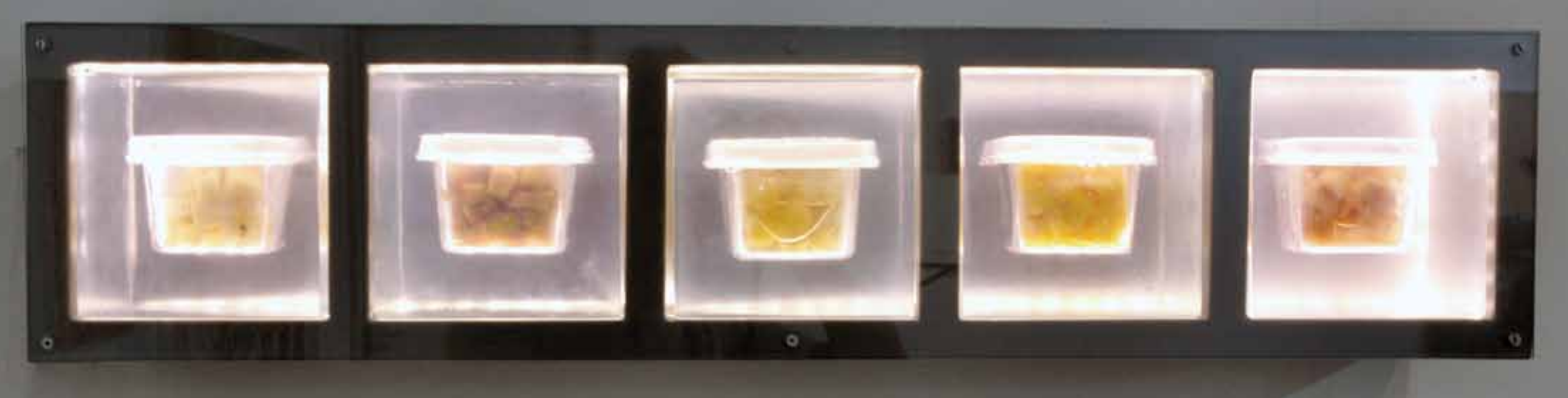

Nessa estetização de hábitos comuns, corriqueiros e não glamourosos, natural ao gênero da natureza morta, vemos uma contradiçăo entre o apelo estetico representado pela estrutura de exposição (hiperasséptica, "clean" e bem acabada), o material e procedimento da resina (que também tem acabamento clean sofisticado), e o alimento em processo de decomposição e morte paralisada. A potencial decomposição desse alimento acaba sendo camuflada por uma imagem superficial hiperestética criada nelo encapsulumento, como uma negaç̃o do último estágio da morte, que seria seu completo desaparecimento.

O alimento A catalogação de hábitos culturais comuns. $O$ alimento já pronto para ser comido. O corpo 0 encapsulamento A referência aos sêneros da arte de representação A ironia.

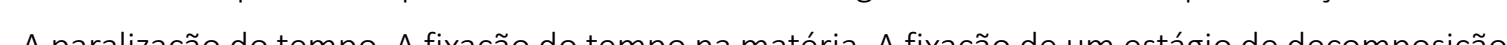
A ciencia A tecnologa. A note. A and

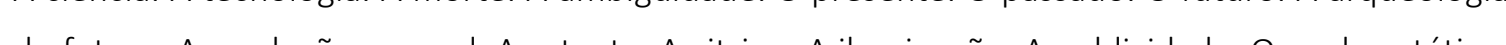
do futuro. A produçăo manual. A estante. Avitrine. A iluminaçâa. A public 


\section{anexo II | vídeos}

Os videos apresentados seguem tanto no corpo do texto como link, quanto em pendrive anexo: Video registro "Incubadora" (2014) : https://vimeo.com/158809727 Animação Projeto “Incubadora”(2019): https://vimeo.com/276264008 Video-performance "Sim, Não, Talvez" (2018): https://vimeo.com/253838085 Video-performance "Making off " (2018) https://vimeo.com/310986930

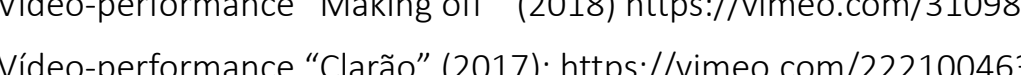
Video "Fluxo" (2018): https://vimeo.com/311079787

\section{Bibliografia consultada:}

AGAMBEN, Giorgio. O que é o contemporâneo? E outros ensaios. Tradução de Vinícius Nicastro Honesko. Chapecó, SC: Argos, 2009

ARANTES, Priscila; NESTERIUK, Sérgio. Programando o visivel: conversas entre Villém Flusser e Harun Farocki. In: AIMEIDA Jane: ARANTES, Priscila: MORAN, Patricia (orss) Harun Farocki Programando o visivel. São Paulo: Pró-reitoria de Culturna Extensão Universitária - USP. 2017. P74-103 Disponivel

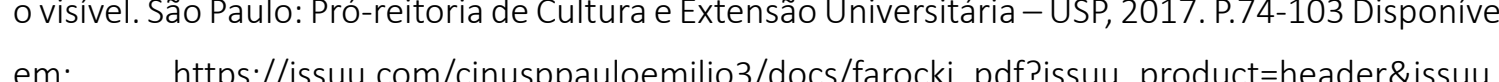

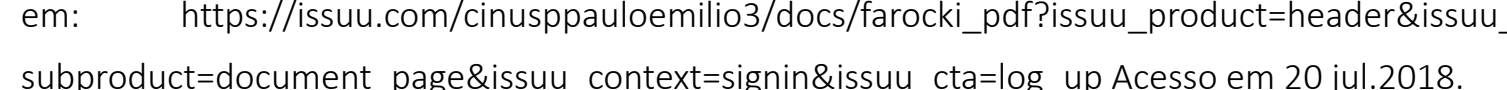

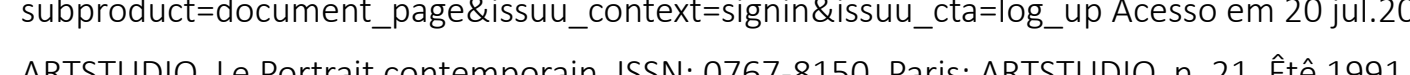

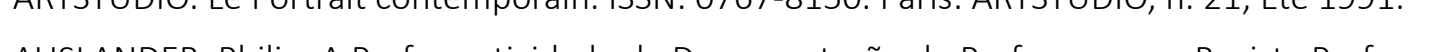
AUSLANDER, A P. A A Pertormatividade da Documentaçăo de Pefromance. eRevista Performatus,

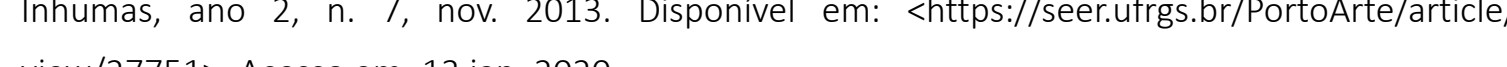
view/27751>. Acesso em: 13 jan. 2020.

BARTHES, Rolland. A Camara clara: Nota sobre a fotografia. Tradução de Júlio Castañon Guimarães. Rio de Janeiro: Nova Fronteira, 1984

BATISTA, Ana Luiza Dias. Língua morta. Tese (doutorado). Programa de Pós-graduação em Artes Visuais - Escola de Comunicaçōes e Artes/Universidade de São Paulo. São Paulo. 2014. Orientação: Sonia Salzstein Goldberg.

BAUDRILLARD, Jean. Sociedade de Consumo. Tradução de Artur Morão. Lisboa: Ediçōes 70, 1995. Sistema de Objetos. Tradução de Zulmira Ribeiro Tavares. São Paulo BAUMAN, Zigmund. Vida para consumo: a transformação das pessoas em mercadoria. Tradução de Carlos Alberto Medeiros. Rio de Janeiro: Jorge Zahar, 2008.

BELTING, Hans. Antropologia da imagem: para uma ciência da imagem. Tradução de Artur Morão Edição, revisão, bibliografia por João Francisco Figueira e Vitor Silva. Lisboa: KKYM + EAUM, 2014. 
Por uma antropologia da imagem. Revista Concinnitas. ano 6, volume 1, número 8, julho 2005. P.64-78. Disponivel em: https://www.academia.edu/7132650/Belting_por_uma_ antropologia_da_imagem Acesso em: 13 jan. 2020.

_ Face and Mask: a double history. Princeton: Princeton University Press, 2017. BENETTI, Liliane. Ângulos de uma caminhada lenta: exercícios de contenção, reiteraçăo e saturação na obra de Bruce Nauman. Tese (doutorado). Programa de Pós-graduação em Artes Visuais - Escola de Comunicaç̄ês e Artes/Universidade de São Paulo. São Paulo. 2013. Orientação: Sonia Salzstein Goldberg.

BENAMIN, Walter. Origem do drama barroco alemão. Tradução, apresentação e notas de Sergio Paulo Rouanet. São Paulo: Editora Brasiliense, 1984.

BOURRIAUD, Nicolas. Pós-produção: como a arte reprograma o mundo contemporâneo. São Paulo: Martins Fontes, 2009.

CERTEAU, Michel de. A invenção do cotidiano: 1. Artes de Fazer. Tradução de Ephrain Ferreira Alves. Petrópolis: Vozes, 1994.

CLARK, Lygia. Da supressão do objeto (anotaçōes). In: FERREIRA, Glória; COTRIM, Cecilia (org). Escritos de artistas: Anos 60/70. Rio de Janeiro: Jorge Zahar, 2006. p.351-356.

CLARK,T.J. "Grotesco David com a bochecha inchada." In: CLARK,T.J.; ; SALZSTEIN, Sonia (Org). MODERNISMOS. São Paulo: Cosac Naify, 2007

COSTA, L.C. Da grade múttipla da montagem: perspectivas para a imagem crítica na contemporânea.

MODOS. Revista de História da Arte. Campinas, v 1, n.2, p. 98-112, mai. 2017 . Disponível ent:

http://www.publionline.jar.unicamp.br/index.php/mod/article/view/76

COURTINE, lean-Jacques: HAROCHE, Claudine. História do rosto. Exprimir e calar as suas emoräes

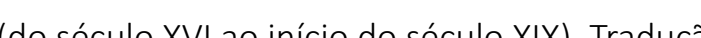

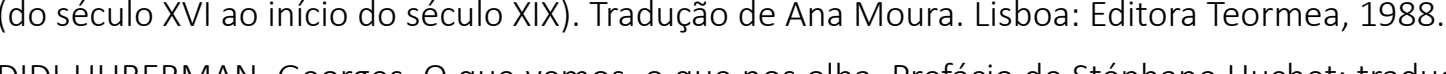
de Paulo Neves. 2a ed São Paulo: Editora 34, 2010.

O Rosto e a terra: Onde começa o retrato, onde se ausenta o rosto
https://seer.uffgs.br/PortoArte/article/view/27751 Acesso em: 10 mar. 2019

DUBOIS, Philippe. O Ato Fotogrático e Outros Ensaios. Tradução de Marina Appenzeller Campinas: Papirus Editora, 1993.

A foto-autobiografia: a fotografia como imagem-memória no cinema documental REVISTA IMAGENS. Número 4. Campinas: Editora da Unicamp, Abril 1995. p.64 - 76. ECO, Umberto. Sobre os espelhos e outros ensaios. Tradução de Beatriz Borges. Rio de Janeiro: Editora Nova Fronteira, 1989

FABRIS, Annateresa. Redefinindo o Conceito de Imagem. Rev. bras. Hist., são Paulo, v. 18, n. 35, p. 217-224, 1998. Disponivel em: http://dx.doi.org/10.1590/50102-01881998000100010. Acesso em 23 dez.2019.

FLATLEY, JONATHAN. Like Andy Warhol [Assim Como Andy Warhol]. In: MESA, Instituto (org), OSORIO, Luiz Camillo (col.). Flipping Revisitando Pop: estética e política nas américas 1967 -2017. Publicação digital. Seminário Internacional Flipping: revisitando Pop. São Paulo: MAM SP. p.12 - 41. FLUSSER, Villém.Filosofia da caixa preta: ensaios para uma futura filosofia da fotografia. Rio de Janeiro: Relume Dumará, 2002.

Mundo Codificado. Organização de Rafael Cardoso. Tradução de Raquel AbiSamara. São Paulo: Cosac Naify, 2007

FOSTER, Hal. O retorno do real: a vanguarda no final do século XX. Traduç̃o de Célia Euvaldo. $1^{\text {as }}$ ed. São Paulo: Cosac Naify, 2014.

FOUCAULT, Michel. A historia da sexualidade I: vontade de saber. Tradução de Maria Thereza da

Costa Albuquerque e J. A. Guilhon Albuquerque. 4å. Ed. Rio de Janeiro: Ediç̄öes Graal, 1977.

FREUD, sigmund. O inquietante. In: FREUD, sigmund. Obras Completas Volume 14: História de

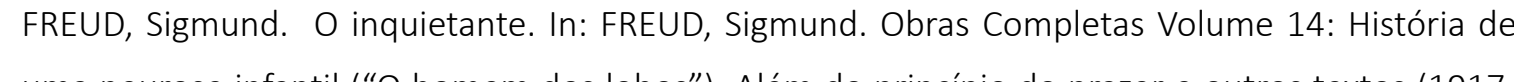
1920). Traduçăo de Paulo César de Souza. Săo Paulo: Companhia das Letras, 2010. GOFFMAN, Erving. A representação do eu na vida cotidiana. Traducão de Maria Célia Santos 
Raposo. 13ạ ed. Petrópolis: Editora Vozes, 2005

GONTIJO, Juliana. Distopias Tecnológicas. 1e ed. Rio de Janeiro: Editora Circuito, 2014

KRAUSS, Rosalind. Notes on the Index: Seventies Art in America. October. Vol. 3 (Spring, 1977), pp.

68-81 Published by: The MIT Press Stable URL: http://www.jstor.org/stable/778437 Accesso em 09 abril 2010 .

Grids. In: KRAUSS, Rosalind. The Originality of the Avant-Garde and Other Modernist Myths. London: MIT Press Cambridge, 1986. p.9-22. Cindy Sherman 1975-1993. New York: Rizzoli, 1993

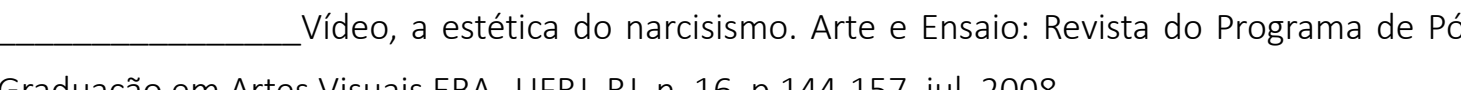
Graduaç̃o em Artes Visuals EBA URN, N, n. 16, p.144-157, jul. 2008

LACAN, Jacques. O estádio do espelho como formador da função do eu. In: ZZZEK, Slavoj (org). Um

mapa da ideologia. Tradução de Vera Ribeiro. Rio de Janeiro: Contraponto, 1996. P.97-104.

LAROUSSE, Ática. Dicionário da lingua portuguesa. - Paris: Larousse/ São Paulo: Ática, 2001

LÉVY, Pierre. O que é o virtual? Tradução de Paulo Neves. São Paulo: Editora 34, 1996. Les Téchnologies de l'Intelligence. Paris: Seuil, 1993

LIPOVETSKY, Gilles; SERROY, Jean. A estetização do mundo: Viver na era do capitalismo artista. Tradução de Eduardo Brandão. 1? ed. São Paulo: Companhia das Letras, 2015.

MCEVILLEY, Thomas. Sculpture in the age of doubt. New York: Allworth Press, 1999.

MEDEIRO S, Margarida. Fotografia e Narcisismo: o auto-retrato contemporâneo. Lisboa: Assírio Alvim, 2000.

MELLO, Christine Extremidades do video: o video na cultura digital. São Paulo: Editora Senac Sミ0 Paulo, 2008.

MESA, Instituto (org): OSORIO, Luiz Camillo (col). Flipping I Revisitando Pop: estética e politica (a)

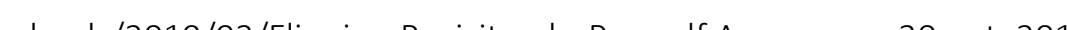
uploads/2019/03/ Tha
MONTEIRO, Katia Canton. Auto-Retrato, Espelho de Artista. 2002. Tese (Livre Docência em Teoria e Critia de Artes)- Escola de Comunicaçôes e Artes, Univers dol.10.11606/.27.2019.tde-24052019-154012. Acesso em 20 dez. 2019

(Przer Visual e Cinema Narrativo" In: XAVIF, Ismail (Org). A Experiência do Cinema: antologia. Rio de Janeiro: Graal, 1983.

A Phantasmagoria of the Female Body: The Work of Cindy Sherman. New Left Review .188 (Jal A - August 1991). P.137-150.

OLVEIRA JUNIOR, Antonio Wellington de. A performance ensaiada: sobre a atualidade das investigaçoes em performance. In: Antonio Wellington de Oliveira Jv. (Org.). A performance ensaiada: ensaios sobre performance contemporânea. Fortaleza: Expressão Gráfica, 2011, p. 09 14.

PARENTE, André (org.e curadoria). Preparaçōoes e tarefas: Leticia Parente. Versão para inglês de Daniela Faria. São Paulo: Paço das Artes, 2008.

PELBART, Peter Pál. Biopolitica. Sala Preta, n.7, 2007, p.57-66. Disponivel em:

http://www.revistas.usp.br/salapreta/article/view/57320/60302. Acesso em: 20/06/2016. PERNIOLA, Mario. Do Sentir. Tradução de Antônio Guerreiro. Lisboa: Editorial Presenņ̧, 1993. 2005 .

PHELAN, Peggy. Unmarked: The politics of performance. London: Routtedge, 1993.

PLAZA, J. Arte/cieincia: uma consciência. Revista ARS. São Paulo. v1 n 1. p. 37-47. 2003.

PRADO, Gilbertto; TAVARES, Monica; ARANTES, Priscila (organizadores). Diálogos transdisciplinares:

arte e pesquisa. São Paulo: ECA/USP, 2016.

RIBEIRO, Gisele Brbosa. A performance / p performativo / a performatividade linnugem e acão

(emprom

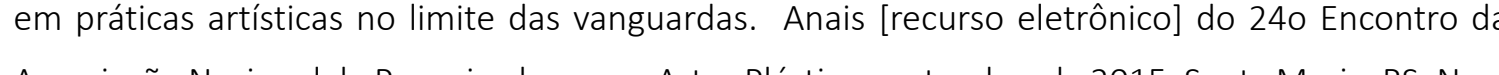

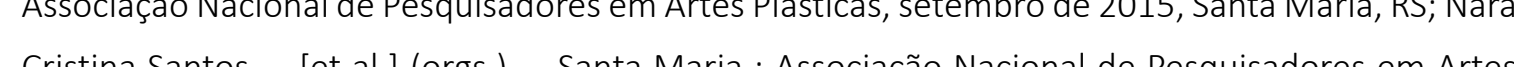
Cristina Santos ... (et al.) (orgs.). - - Santa Marila: A Associaçăo Nacional de Pesquisadores em Artes 
Sul, PPGAV, 2015. P. 255-271

RIVERA, Tânia. O avesso do imaginário: Arte Contemporânea e Psicanálise. São Paulo: Cosac Naify,

2013.

ROLNIK, Suely. Arquivo para uma obra-acontecimento: Projeto de ativação da memória corporal de uma trajetória artística e seu contexto. Apresentação Danilo Santos de Kiranda, Juca Ferreira, Afons Luz e Corinne Diserens. São Paulo: SESC, 2011. Disponivel em: https://issuu.com/edicoessescsp/ docs/arquivoparaumaobra Acesso em: 10 dez. 2019 .

SAFATL, Vladimir. P. O que vem depois da imagem de si? Os casos Cindy Sherman e Jeff koons. In: Milinitzky, F́tima (org.) Narcisismo: o vazio na cultura e a crise do sentido. Goiãnia: Dimensão Editorial, 2006, p.131-146.

SALLES, Cecilia Almeida. Gesto Inacabado: processo de criação artística. 5 a ed. Revista e ampliada

São Paulo: Intermeios, 2011

SANTAELLA, Lúcia. O homem e a máquina. In: DOMINGUES, Diana (org). A arte no século XXI: a humanização das tecnologias. São Paulo: Fundação editora da UNESP, 1997. p.33-p.44. Corpo e comunicação: sintoma da cultura. São Paulo: Paulus, 2004.

Por que as comunicaç̄oes e as artes estão convergindo? São Paulo: Paulus, 2005.

SENNETT, Richard. O artifice. Rio de Janeiro: Record, 2009

SIBILA, PAULA. O show do eu: a intimidade como espetáculo. Rio de Janeiro: Nova Fronteira, 2008. Ohomem pós-orgânico: corpo, subjetividade e tecnologias digitais $3^{3}$ ed. Rio de Janeiro: Relume Dumará, 2006.

SIMONDON, Gilbert. El modo de existencia de los objetos técnicos. 1ำ ed. Buenos Aires Prometeolibros, 2007.

SOLEDAR, Jorse Liz Dutra Como me tornei insensivel. Rio de Janeiro. Figo Prestígio Editoriat 2014 Exerćcicios de Imobilidade. Tese (doutorado). Programa de PósGraduação em Artes Visuais da Universidade Federal do Rio de Janeiro. Rio de Janeiro, 2017. ação: Profa. Dra. Simone Michelin.
Visuais - Escola de Comunicaç̋es e Artes/ Universiddde de São Paulo. São Paulo. 2019. Orientação: Prof. Dr. Hugo Fernando Salinas Fortes Junior

SITES:

Filme "Lygia Clark - Memória do corpo (1984). Disponivel em: https://www.youtube.com/ 20 junho 2017

Vídeo "MÁSCARAS SENSORIAII" produzido pela Clark Art Center e Associação Cultural "O Mundo de Lygia Clark. Disponivel em: https://www.youtube.com/watch?v=0kz-WIORsZg Acesso em 20 junho 2017.

Site da exposição "Lygia Clark: uma retrospectiva" - Itaú Cultural. Disponivel em: http:// www.tiaucultural.org.br/programe-se/agenda/evento//ygia-clark-uma-retrospectiva-observeinteraja-participe-da-arte/ Acesso em 20 junho 2017.

Entrevista com Gillian Wering: Disponivel em:

https://www.52-insights.com/gillian-wearing-we-need-approach-life-with-the-notion-we-are-

all-mentally-ill-art-interview/ Acesso em 20 dez. 2019

Entrevista com Laura Lima, Prêmio Pipa: Disponivel em: https://www. premiopipa.com/pag/ artistas/laura-lima/entrevista-com-laura-lima-transcricao/ Acesso em 20 dez. 2019. 


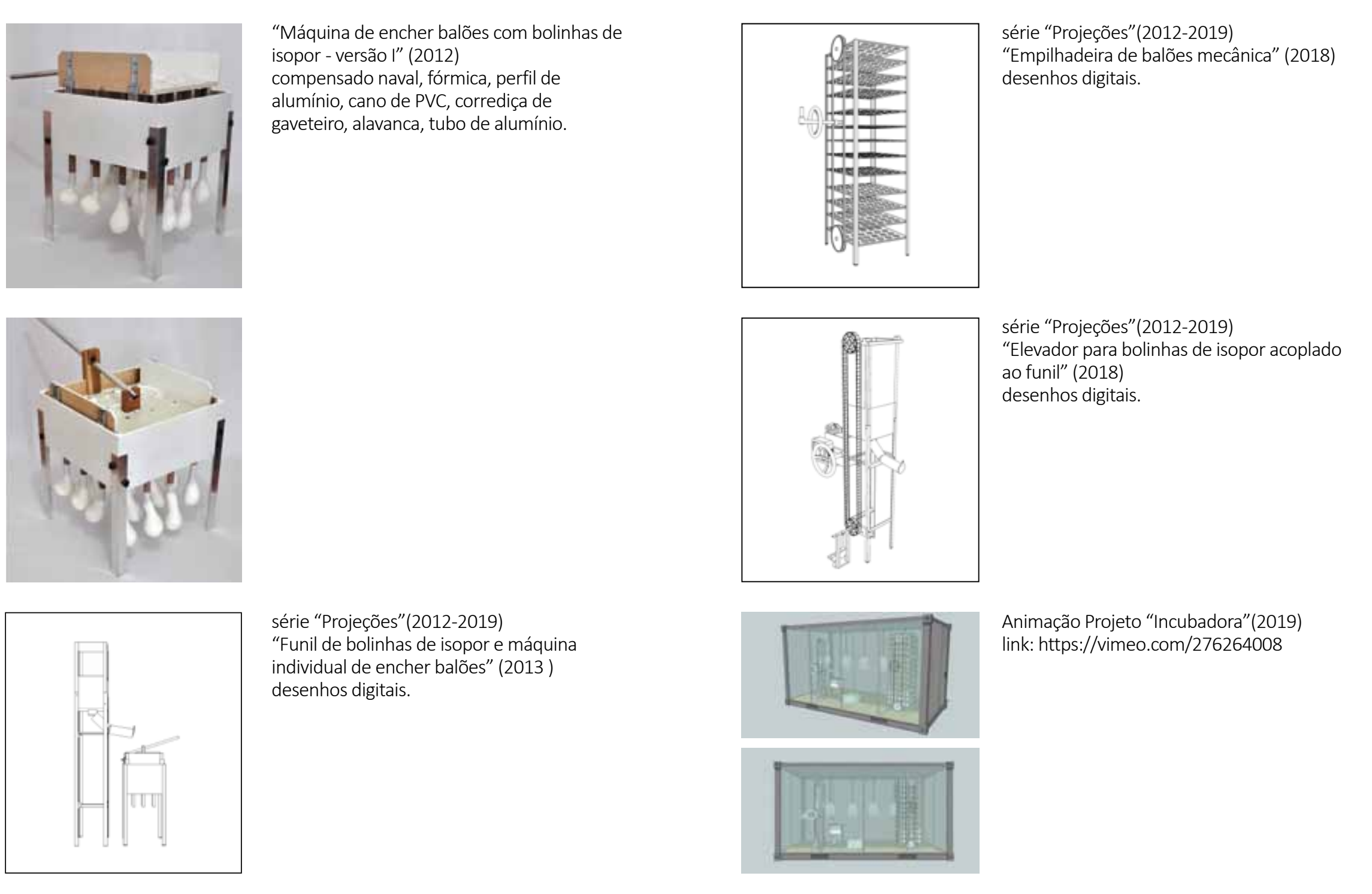

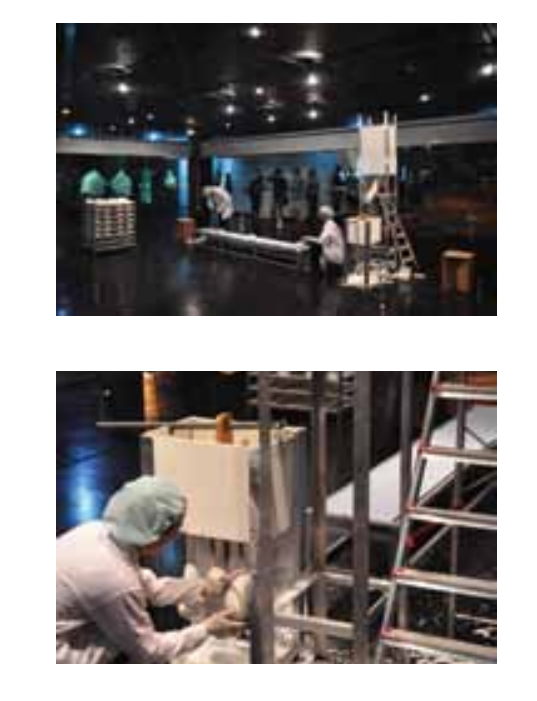

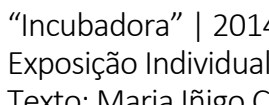

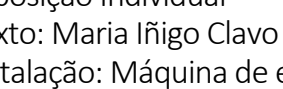

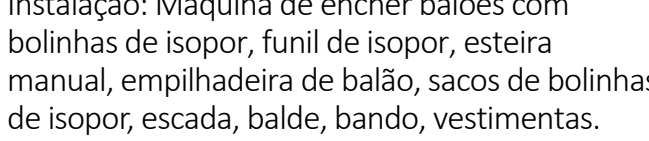
Performannce: Cláudio Tobinaga e L Leandra Espin

Danto ãão : 2:30 horas (aprox.)
Local: Centro Cultural Paschoal Carlos Magno,

Niteréi (RJ)
Projeto anhador da "Chamada Artes Visuais",
(20issj) O

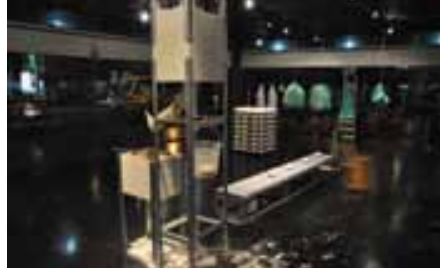

Scilioto (2014), foi selecionadodo paranoa osalăo

realizado dentro do evento de performance,

Instauracãa" " no Sesc Belenninho (SP-2017)
convidado articipar da Bienallur (2019).

Link video registro: http://leandraespiritosanto
net /fincubadodora

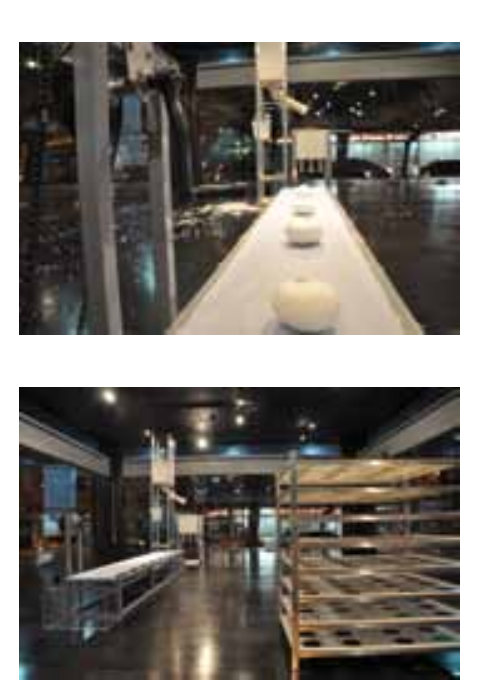

"Sim, nõo, talvev" (2018)
video realizada a partir de fotografia performada

a

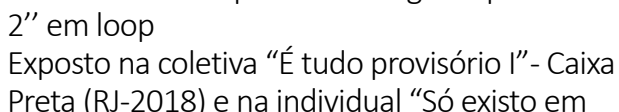

terceira pessoa"'- Galeria Fernanda

Milani (Jundiai-2019).
link: https://vimeo. com/253838085

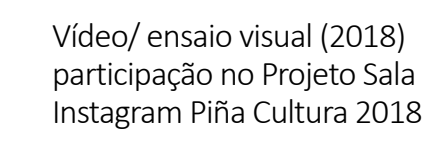




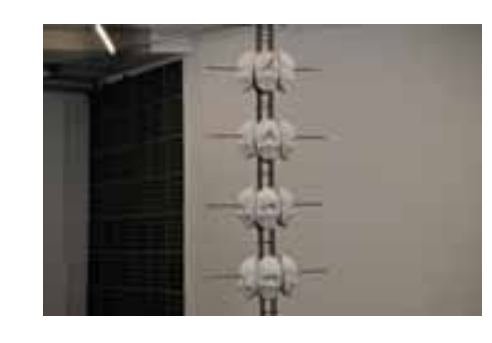

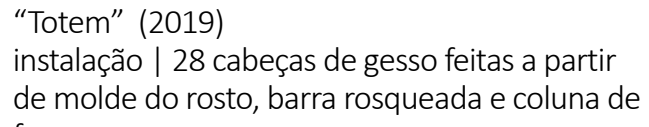

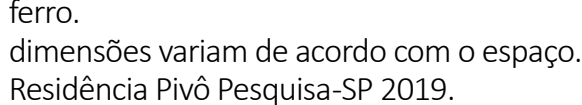

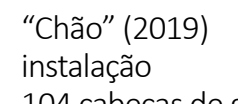

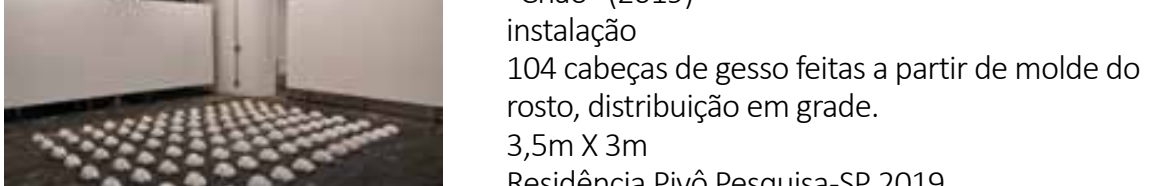

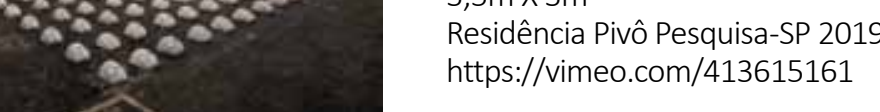

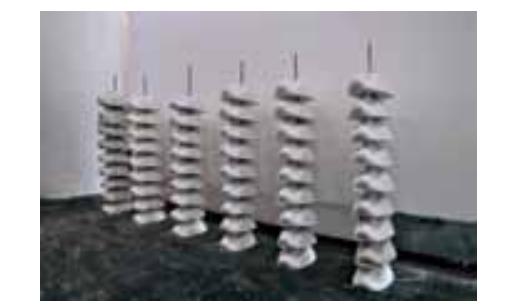

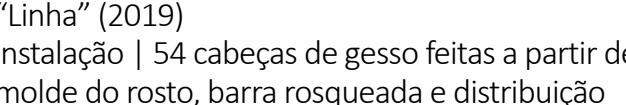

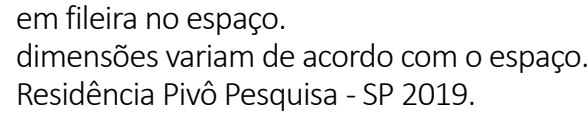

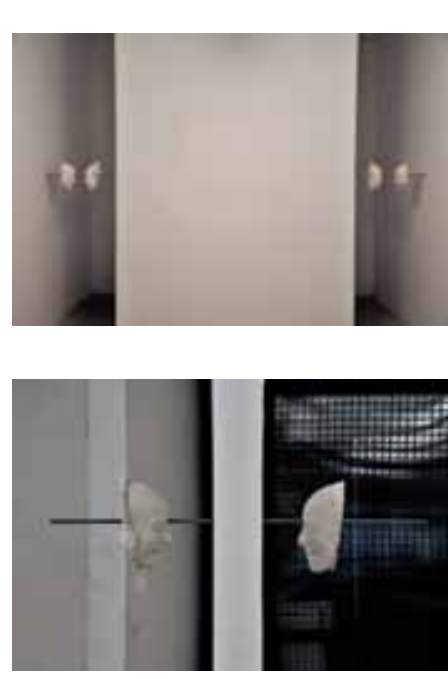

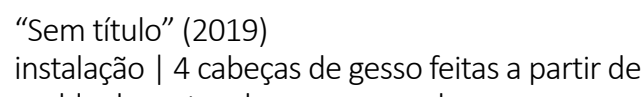

molde do rosto barra rosqueada.

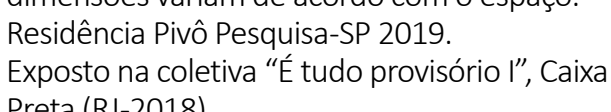

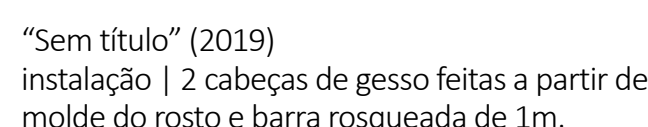

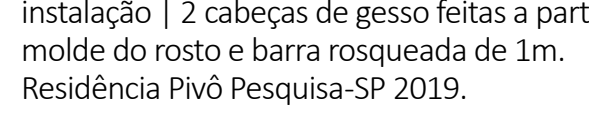

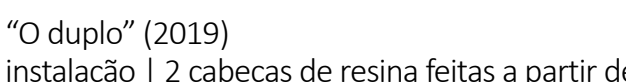

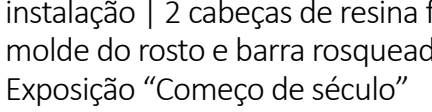

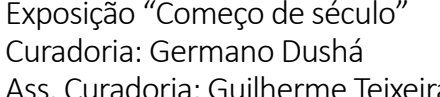

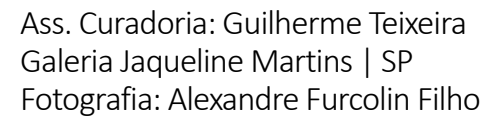

"Positivo - śérie Gestos" (2019)
instalacăo 10 mâos de resina feitas a partiri de

molde do corpo o barra rosqueadada.
$2,25 \mathrm{~m}$ larg $\times 15 \mathrm{~cm}$ alt $\times 5 \mathrm{~cm}$ prof

Curadoria: Ulisses Carriliho

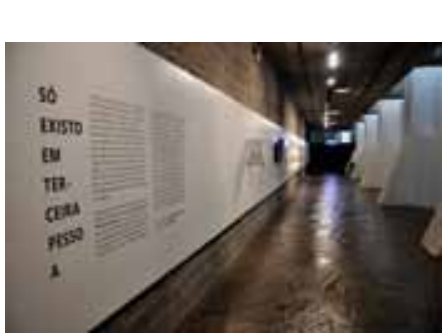

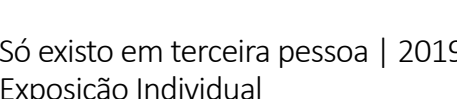

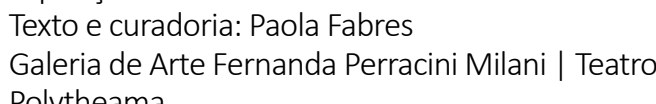

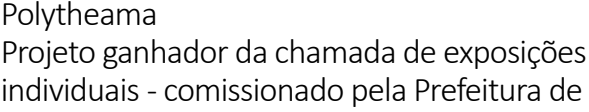

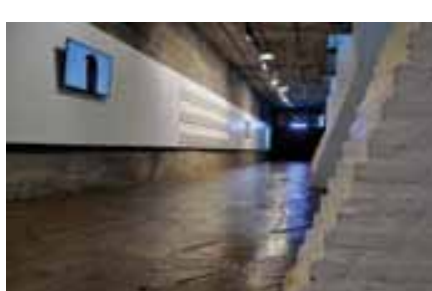

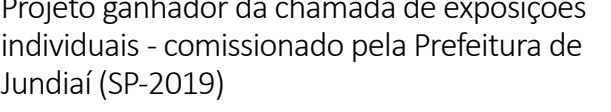

Galeria Simone Cadinelli (RJ-2019)

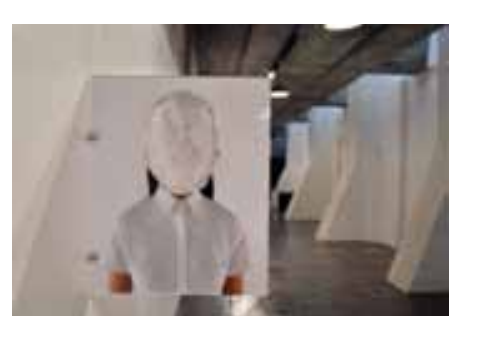

"Slêtrcio e Capa - série apagamento" (díptico| fotografia performada
metacrilato dupla-face
$40 \mathrm{~cm}$ alt $\mathrm{x} 33 \mathrm{~cm}$ larg

Texto e curadoria: Paola tarchres pessoa" (2019) Galeria de Arte Eernandd Perracini Milani
Expostas Aatabém no Salâa Novissimos-Galeria
lbeu (2017-RI).
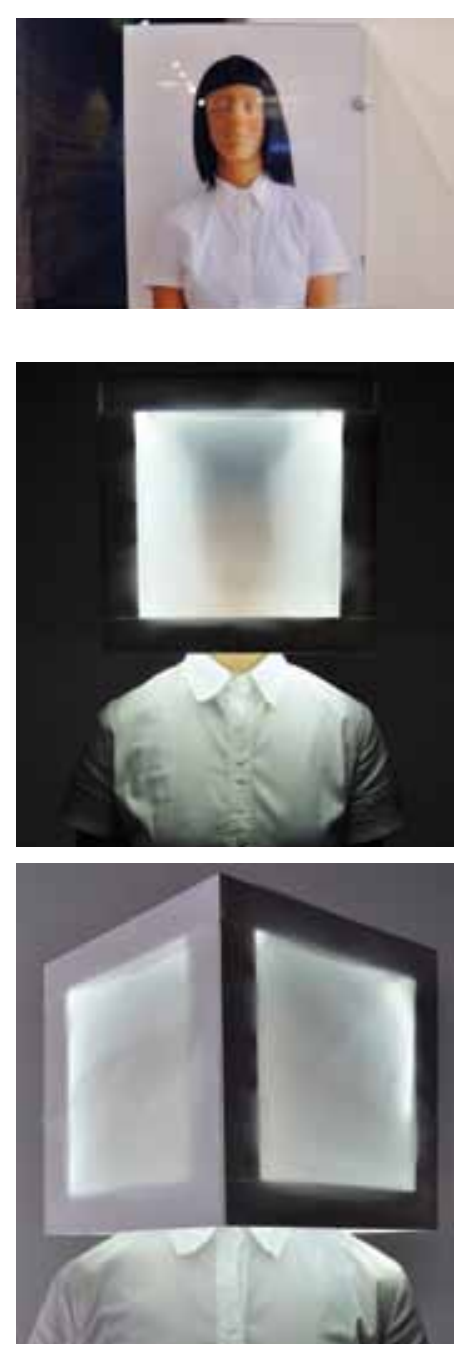

"lapso Ennquadre - sére apagamento" (diptica)

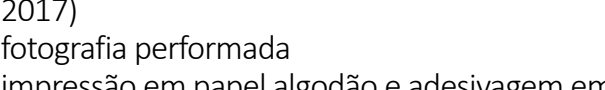

Ps $m$ alt $x 580$.

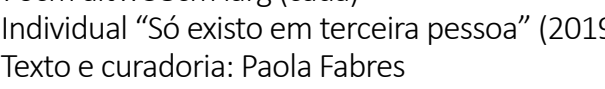

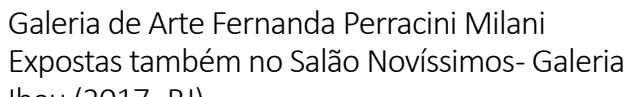

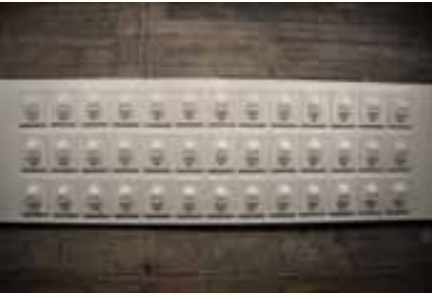

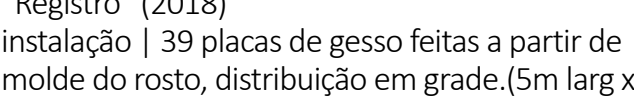

Idividual 'so existo en tercerira pesson" (2019)

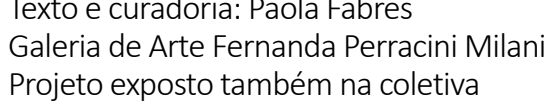

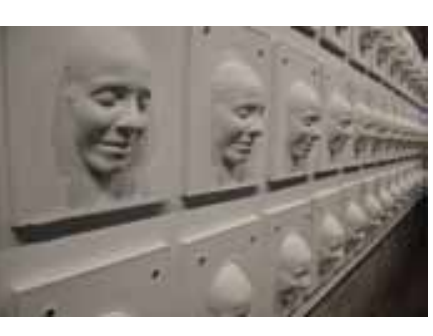

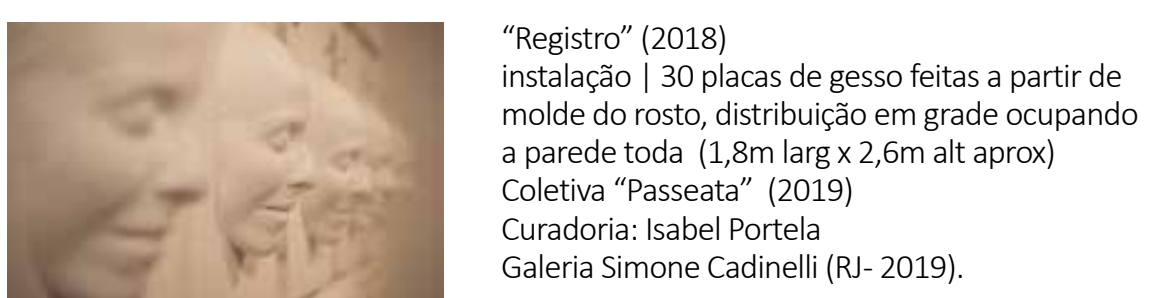

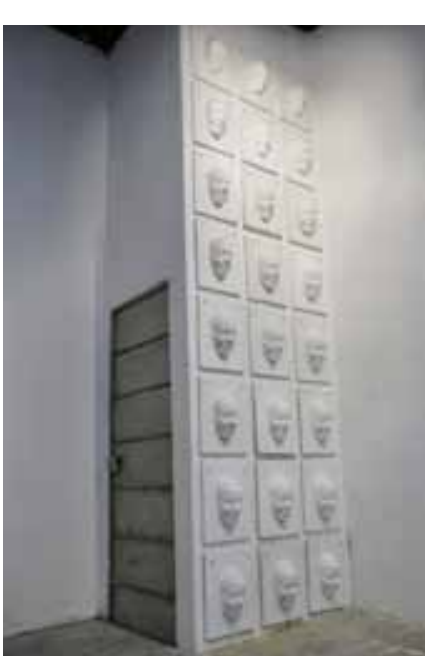

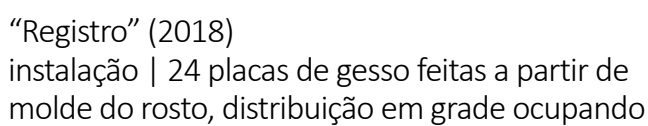

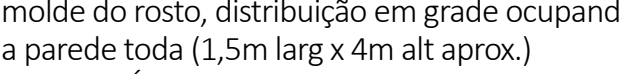

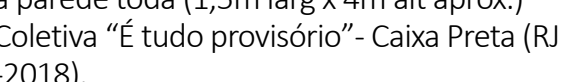




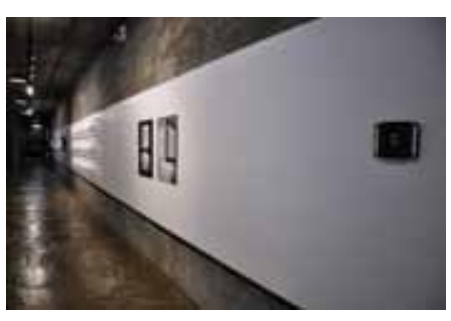

“Clarão - série apagamento" (2017)

vídeo feito a partir de fotografia performada.

Individual "Só existo em terceira pessoa".

Texto e curadoria: Paola Fabres

Galeria de Arte Fernanda Perracini Milani.

Expostas também no Salão Novíssimos- Galeria

Ibeu (2017- RJ).

Link: https://vimeo.com/222100463
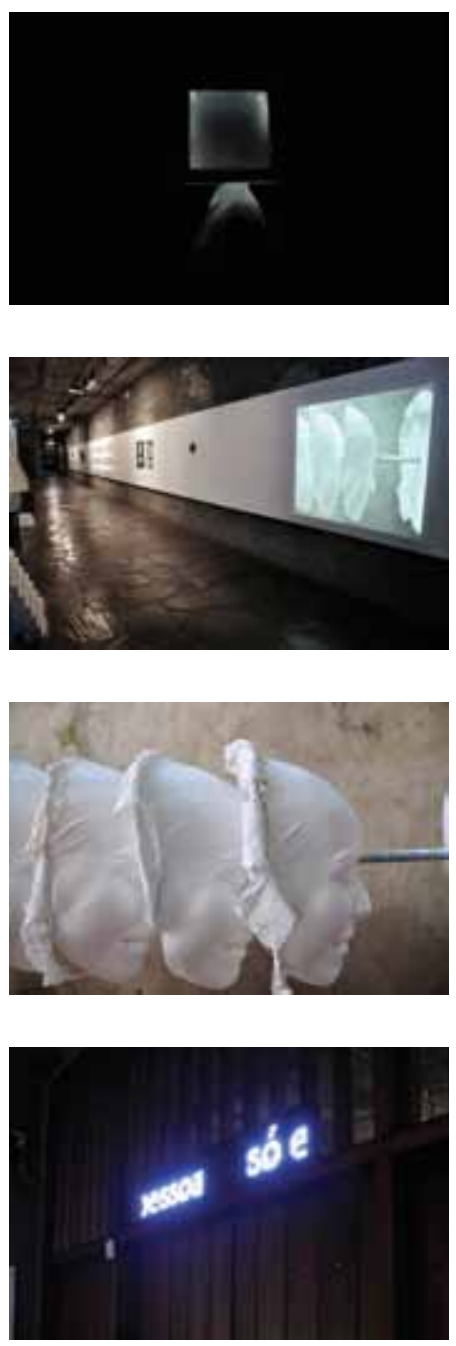

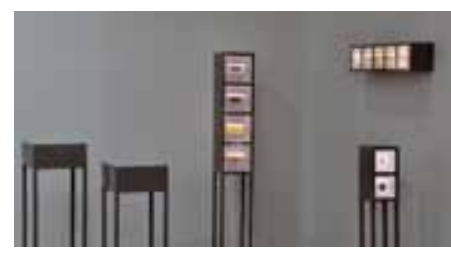

"Natureza-morta" (2019)

Resina transparente, comida encapsulada,

estrutura de metal iluminada com fita de led.

dimensões variáveis

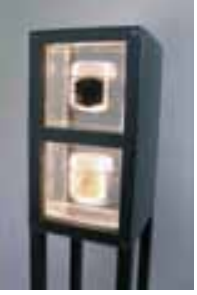

"Fluxo" (2018)

vídeo stopmotion

2" em loop | projeção

Individual "Só existo em terceira pessoa".

Texto e curadoria: Paola Fabres

Galeria de Arte Fernanda Perracini Milani

Exposto também no Projeto Sala - Piña Cultural

(2018).

Link: https://vimeo.com/311079787

"Terceira Pessoa" (2019)

objeto | letreiro de led ( $1 \mathrm{~m}$ larg $\times 20 \mathrm{~cm}$ alt $\times 5$

$\mathrm{cm}$ prof) passando a frase "Só existo em terceira pessoa"

Individual "Só existo em terceira pessoa".

Texto e curadoria: Paola Fabres

Galeria de Arte Fernanda Perracini Milani
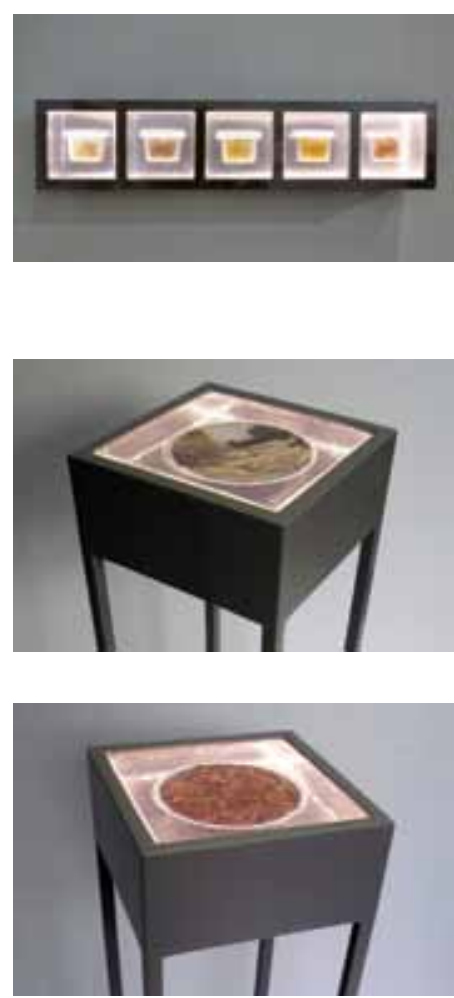

"Natureza-morta - Prato Feito (arroz, feijão, batata-frita, bife)" (2019)

1 placa de resina transparente, comida

encapsulada, estrutura de metal iluminada com fita de led.

$29 \mathrm{~cm}$ larg x $100 \mathrm{~cm}$ alt $\times 29 \mathrm{~cm}$ prof

“Natureza-morta - Arroz e Feijão (arroz, feijão, pote de vidro)" (2019)

cubos de resina transparente, comida

encapsulada, estrutura de metal iluminada com fita de led.

$16 \mathrm{~cm} \operatorname{larg} \times 120 \mathrm{~cm}$ alt x $16 \mathrm{~cm}$ prof.

"Natureza-morta - Salada de frutas (abacaxi, goibada, manga, uva, maçã, potes de plástico)" (2019)

) $(12 \mathrm{~cm} \times 12 \mathrm{~cm} \times$ , comida encapsulada, estrutura de metal iluminada com fita de led.

$72 \mathrm{~cm}$ largx $16 \mathrm{~cm}$ alt $\times 14 \mathrm{~cm}$ prof.

"Natureza-morta - Macarrão a bolonhesa" (2019)

1 placa de resina transparente, comida encapsulada, estrutura de metal iluminada com fita de led.

$29 \mathrm{~cm} \operatorname{larg} \times 100 \mathrm{~cm}$ alt $\times 29 \mathrm{~cm}$ prof 